\title{
Evaluatie van de RUBS-schoolverlatersenquete 1989
}

Citation for published version (APA):

de Grip, A., \& van Dam, J. W. (1990). Evaluatie van de RUBS-schoolverlatersenquete 1989.

Researchcentrum voor Onderwijs en Arbeidsmarkt, Faculteit der Economische Wetenschappen. ROA Reports No. 2 https://doi.org/10.26481/umarep.1990002

Document status and date:

Published: 01/01/1990

DOI:

10.26481/umarep.1990002

Document Version:

Publisher's PDF, also known as Version of record

\section{Please check the document version of this publication:}

- A submitted manuscript is the version of the article upon submission and before peer-review. There can be important differences between the submitted version and the official published version of record.

People interested in the research are advised to contact the author for the final version of the publication, or visit the DOI to the publisher's website.

- The final author version and the galley proof are versions of the publication after peer review.

- The final published version features the final layout of the paper including the volume, issue and page numbers.

Link to publication

\footnotetext{
General rights rights.

- You may freely distribute the URL identifying the publication in the public portal. please follow below link for the End User Agreement:

www.umlib.nl/taverne-license

Take down policy

If you believe that this document breaches copyright please contact us at:

repository@maastrichtuniversity.nl

providing details and we will investigate your claim.
}

Copyright and moral rights for the publications made accessible in the public portal are retained by the authors and/or other copyright owners and it is a condition of accessing publications that users recognise and abide by the legal requirements associated with these

- Users may download and print one copy of any publication from the public portal for the purpose of private study or research.

- You may not further distribute the material or use it for any profit-making activity or commercial gain

If the publication is distributed under the terms of Article $25 \mathrm{fa}$ of the Dutch Copyright Act, indicated by the "Taverne" license above, 
EVALUATIE VAN DE RUBS-SCHOOLVERLATERSENQUETE 1989

ROA-R-1990/2

A. de Grip

J.W. van Dam

RESEARCHCENTRUM VOOR ONDERWIJS EN ARBEIDSMARKT

Faculteit der Economische Wetenschappen

Rijksuniversiteit Limburg

Maastricht, juni 1990 
CIP-GEGEVENS KONINKLIJKE BIBLIOTHEEK, DEN HAAG

Grip, A. de

Evaluatie van de RUBS-schoolveriatersenquête 1989/ A. de Grip, J.W. van Dam. Maastricht: Researchcentrum voor Onderwijs en Arbeidsmarkt, Faculteit der Economische Wetenschappen, Rijksuniversiteit Limburg. Researchcentrum voor Onderwijs en Arbeidsmarkt, ISSN 0922-4645; 1990/2.

Mt lit. opg.

ISBN 90-5321-036-9

SISO 450.3 UDC $303.62: 373.5$

Trefw.: schoolverlaters; onderzoek. 
VOORWOORD

1. INLEIDING

1.1. Voorgeschiedenis

1.2. Het RUBS-pilotproject $1988 / 1989$

1.3. Indeling van het rapport

2. DE RUBS-ENQUETE VAN 1989

2.2. Doelstelling van de RUBS-enquête 1989

2.3. De onderzoekpopulatie: definitie en steekproef 7

2.4. De vragenlijst

2.5. Uitvoering van het onderzoek

2.5.1. Organisatie van de dataverzameling 12

2.5.2. Respons en non-respons onderzoek 16

2.5.3. Codering en verwerking 19

2.6. Rapportage

3. HET TOEKOMSTIGE AANBOD VAN SCHOOLVERLATERS 29

3.1. Doelstelling en opzet 29

3.2. Evaluatie 30

4. DE TOEKOMST VAN RUBS ALS INFORMATIE-INSTRUMENT 34

4.1. Inleiding 34

4.2. Gebruikersgroepen en informatieprodukten 34

4.2.1. Gebruiksdoelen en gebruikersgroepen 34

4.2.2. Informatieprodukten 41

4.3. Onderzoekopzet 45

4.3.1. Aspecten van de onderzoekopzet 45

4.3.2. De algehele onderzoekopzet 51

4.4. Mogelijke organisatie- en financieringsstructuur 58

4.4.1. Afbakening van activiteiten 58

4.4.2. Centrale beheersinstantie 62

4.4.3. Onderzoekkosten en mogelijke financieringsbronnen 65

4.5. De verdere ontwikkeling van RUBS 72 
BIJLAGE I : SAMENSTELLING PROJECTTEAM

BIJLAGE II : SAMENSTELLING BEGELEIDINGSCOMMISSIE

BIJLAGE III : VRAGENLIJST PILOTPROJECT (EERSTE DEELPROJECT)

BIJLAGE IV : OPMERKINGEN COA'S OVER VRAGENLIJSTEN

BIJLAGE $V$ : TAAKVERDELING EN TIJDSPLANNING PILOTPROJECT

BIJLAGE VI : SAMENWERKINGSOVEREENKOMST ROA-COA

BIJLAGE VII : VRAGENLIJST NON-RESPONS ONDERZOEK 
VOORWOORD

Maandagmiddag 3 juni 1985 kreeg ik bezoek van een mij onbekende Dick Hermans, die mij uitnodigde deel te nemen aan een studiedag over arbeidsmarktinformatie voor studie- en beroepskeuze. Dick was verbonden aan de Katholieke Universiteit te Nijmegen en was lid van de werkgroep van de Landelijke Commissie voor de Academische Studievoorlichting (LCAS) die de studiedag organiseerde. Ik was toen nog werkzaam bij het Nederlands Economisch Instituut (NEI) te Rotterdam en had mij daar ondermeer bezig gehouden met het opstellen van arbeidsmarktprognoses voor beroepen en opleidingen.

Die bewuste maandagmiddag bracht hij het plan naar voren om een systeem te ontwikkelen voor het registreren van de bestemming van de uitstroom van opleidingen op de arbeidsmarkt en in het vervolgonderwijs. De scholen zouden zelf een actieve rol moeten spelen bij het verzamelen van de gegevens. Door aggregatie van de verkregen gegevens over meer scholen zouden zij een beeld krijgen van de arbeidsmarktpositie van de verschillende opleidingen en de positie van de school ten opzichte van het regionale en landelijke beeld. Dergelijke gegevens zouden een belangrijke richtsnoer kunnen vormen voor de studiekeuze van leerlingen. Door koppeling van de uitstroomgegevens aan gegevens over de instroom in opleidingen zou het systeem naar zijn mening een prognostisch karakter kunnen krijgen: Het systeem zou hierdoor een dempende invloed kunnen hebben op de "varkenscycli" in de studiekeuze van leerlingen.

De studiedag werd gehouden op 21 november 1985. Er waren verschillende voordrachten, waaronder de voordracht van Dick Hermans over zijn registratiesysteem van schoolverlaters en mijn voordracht over de arbeidsmarktprognoses van beroepen en opleidingen, die het NEI in opdracht van de Organisatie voor Strategisch Arbeidsmarktonderzoek (OSA) had samengestelda. Dick bracht zijn originele plannen met verve naar voren. In werkgroepen werd uitgebreid het nut en de uitvoerbaarheid besproken. Over het nut van de gegevens was men het snel eens. Je moet leerlingen zo goed mogelijk informeren over de kansen met een bepalde opleiding op werk. Registratie van een aantal basisgegevens over de positie van schoolverlaters op de arbeidsmarkt kan tot een aanmerkelijke verbetering leiden van de huidige

a. Vgl. voor een uitvoerig verslag van deze dag en de gehouden voordrachten: B.M.J. Hermans (red.), Kiezen van de baan, Verslag studieconferentie 21 november 1985, LCAS, maart 1986. 
zeer gebrekkige voorlichtingsgegevens. Voor de praktische uitvoering van het registratieplan kwamen al snel de Contactcentra Onderwijs-Arbeid (COA's) in beeld, die deels reeds activiteiten in deze richting ontplooiden. In aansluiting hierop werd de noodzaak genoemd van bundeling van hun inspanningen, alsmede de ontwikkeling van een landelijk beleidskader, voor het opzetten van experimenten en de definitieve uitvoering van het registratieplan.

Hoewel tijdens die gedenkwaardige studiedag reeds vele aspecten werden besproken die nu in de huidige plannen zijn verwerkt, duurde het enkele jaren voordat met een experiment kon worden begonnen. Inmiddels had ik het NEI verruild voor de Rijksuniversiteit Limburg, om daar het ROA te starten voor de uitvoering van een opdracht van het Ministerie van Onderwijs en Wetenschappen om een informatiesysteem onderwijs-arbeidsmarkt te ontwikkelen. Al snel bleek voor uitvoering van die opdracht een gebrek aan strategische informatie voor verfijning van de te ontwikkelen prognosemodelien en statistische indicatoren betreffende de aansluiting tussen het onderwijs en de arbeidsmarkt. Het was daarom een gelukkige greep dat bij de uitvoering van het experiment Registratie van de Uitstroom en Bestemming van Schoolverlaters (RUBS) naast de uitvoerders LCAS/CORO en COA's ook de wetenschappelijke instituten RION en ROA werden ingeschakeld, die de betekenis van de te verzamelen gegevens als statistische basis voor onderzoek konden overzien.

Het verslag van de experimentele fase van RUBS is nu gereed. Het vormt het resultat van een enthousiaste en zeer gemotiveerde inspanning van een aantal heel verschillende instellingen, die elkaar in een vruchtbare samenwerking hebben gevonden. Veel belangrijker is echter de constatering dat in de loop van de tijd de behoefte aan het soort gegevens dat RUBS kan opleveren alleen mar lijkt te zijn toegenomen. De wereld van studie- en beroepskeuzevoorlichting heeft dringend behoefte aan betrouwbare en onafhankelijke gegevens over de arbeidsmarktperspectieven van opleidingen. Scholen zijn meer geinteresseerd geraakt in de betekenis van hun opleidingen voor de arbeidsmarkt. Nu de eerste volledige versie van het informatiesysteem onderwijsarbeidsmarkt van het ROA is gereed gekomenb, kunnen de RUBS-gegevens een strategische rol vervullen bij de invulling van de plannen voor verdere

b. De Grip, Heijke en Dekker, De arbeidsmarkt naar opleiding en beroep in 1992, ROA-R-1989/8, Maastricht. 
uitbouw en verfijning van dit systeem. Dit zal ook zijn vruchten afwerpen voor de verdere ontwikkeling van het geautomatiseerde studie- en beroepskeuzesysteem I-See!, warin de arbeidsmarktgegevens van het ROA zijn opgenomen. Het aantrekken van de arbeidsmarkt in relatie tot de ontgroening van de bevolking heeft in het bedrijfsleven de belangstelling naar betrouwbare gegevens over de (toekomstige) uitstroom uit de diverse delen van het onderwijs sterk doen toenemen, zodat men tijdig het wervingsbeleid daarop kan afstemmen.

Met grote belangstelling zien de onderzoekers daarom uit naar de beslissingen die naar aanleiding van dit rapport zullen worden genomen. Het valt te hopen dat de desbetreffende beleidsinstanties mogelijkheden zien om de in het rapport gedane voorstellen in enigerlei vorm gestalte te doen geven. De tijd lijkt rijp en het maatschappelijk nut evident.

Prof. dr. J.A.M. Heijke

directeur ROA 
$-i v-$

EVALUATIE VAN DE RUBS-SCHOOLVERLATERSENQUETE 1989

- Samenvatting - 


\section{HET RUBS-PILOTPROJECT $1988 / 1989$}

In het projectvoorstel Registratie van de Uitstroom en de Besteming van Schoolverlaters (RUBS), een samenwerkingsproject LCAS/COA's wordt een drietal hoofddoelstellingen van een RUBS-pilotstudie geformuleerd:

- ontwikkelen van een landelijk bruikbaar meetinstrument ten behoeve van de registratie van de uitstroom van schoolverlaters en hun positie op de arbeidsmarkt;

- ontwikkelen van een eenvoudig model voor de gegevensopslag en verwerking;

- ontwikkelen van globale voorstellen voor landelijke en regionale vervolgprojecten.

Bij de opzet van het pilotproject is een opsplitsing gemakt in een tweetal deelprojecten. Het eerste deelproject betreft een grootschalige enquête onder schoolverlaters voor het achterhalen van de "eerste bestemming" van zowel ongediplomeerde als gediplomeerde schoolverlaters per opleidingsrichting. Door middel van deze enquête wordt tevens een aantal kwalitatieve gegevens verzameld over de aansluiting tussen opleiding en beroep. Dit deelproject is uitgevoerd door de COA's. Voor de wetenschappelijke ondersteuning van dit dee 1 van het project is het RION ingeschakeld.

Het tweede deelproject is gericht op het ontwikkelen van een informatieinstrument met betrekking tot de omvang en de bestemming van het aanbod per opleidingsrichting op de arbeidsmarkt van gediplomeerde schoolverlaters op de middellange termijn. Dit wordt gedaan met gegevens over de bestemming van schoolverlaters in combinatie met gegevens over de leerlingeninstroom. De uitvoering van dit deelproject is verzorgd door het centraal orgaan van de Regionale Organen van het leerlingwezen (CORO) onder verantwoordelijkheid van de LCAS.

Het ROA heeft de coördinatie van de beide deelprojecten op zich genomen en de zorg gedragen voor het evaluerende eindrapport, waarin met name ook ingegaan wordt op een mogelijke grootschalige voortzetting van het RUBSproject.

\section{Evaluatie pilotproject}

Bij de samenstelling van de onderzoekpopulatie voor de enquête onder schoolverlaters is gestreefd naar een landelijk en regionaal zo breed 
mogelijke opzet. Vanwege de grote verschillen in financiële middelen warover de in het eerste deelproject participerende COA's beschikten en de uiteenlopende onderzoekprioriteiten van de diverse regionale financiers van het pilotproject, was het echter niet mogelijk alleen vanuit onderzoektechnische criteria vast te stellen welke scholen in welke regio's in het onderzoek moesten worden betrokken. Wel is het gelukt alle schooltypen uit het reguliere voorgezet onderwijs in het pilotonderzoek op te nemen. Dit had als belangrijk voordeel dat alle mogelijke onderzoektechnische problemen met betrekking tot een specifiek opleldingstype in het pilotonderzoek naar voren konden komen. Daarnaast is het mogelijk gebleken in alle regio's het MDGO in het onderzoek op te nemen. Hierdoor zijn niet alleen alle opleidingstypen uit het voortgezet onderwijs in de RUBS-populatie aanwezig, maar is één bepaalde opleiding ook in alle participerende regio's onderzocht. Dit maakt het mogelijk om voor het MDGO een interregionale vergelijking te maken. Het MDGO fungeert daarmee als een concreet voorbeeld voor een landelijke rapportage die voor ieder schooltype zou kunnen worden samengesteld, wanneer het RUBS-project in de toekomst het gehele Nederlandse voortgezette onderwijs zou bestrijken. Bij de invulling van het pilotproject stond bovendien centraal dat de uitkomsten koppelbaar zouden moeten zijn met belangrijke gegevensbestanden van het CBS, als bijvoorbeeld de Enquête Beroepsbevolking. Deze koppeibaarheid is gerealiseerd door bij de codering van bedrijfssectoren, beroepen en opleidingen nauw aan te sluiten bij de standaard classificaties van het CBS.

In total zijn ruim 40.000 schoolverlaters met een schriftelijke vragenlijst benaderd. Het betrof hier zowel gediplomeerde als ongediplomeerde schoolverlaters. De respons bedroeg gemiddeld $65 \%$; de respons van ongediplomeerden lag echter aanmerkelijk lager. De vragenlijst was met name gericht op de huldige bezigheid van schoolverlaters (vervolgopleiding, werk, werkloos, e.d.), soort bedrijf waar men werkt, beroep, inkomen, eventueel gevolgde cursussen en de aansluiting tussen de gevolgde opleiding en het huidige werk c.q. vervolgopleiding. Daarnaast bevatte de vragenlijst een aantal achtergrondkenmerken van de schooiverlaters. In zijn algemeenheid bleek de ontwikkelde vragenlijst goed te voldoen.

In paragraaf 2.5. van het evaluatierapport wordt een uitvoerige evaluatie gegeven van de uitvoering van het onderzoek, toegespitst op achtereenvolgens de organisatie van de dataverzameling, de respons en het non-respons onderzoek en de codering en dataverwerking. 
Het tweede deelproject was van een veel kleinere omvang. De empirische uitkomsten waren dan ook louter als illustratie bedoeld. Hoewel de ontwikkelde methodiek een goede indicatie kan opleveren van het toekomstige aanbod van schoolverlaters naar regio en vakrichting, levert het alleen in combinatie met prognoses van de vraagzijde van de arbeidsmarkt een prognose van de kans op werk voor schoolverlaters met een bepaalde opleiding. Bovendien werd geconstateerd dat dergelijke prognoses bij voorkeur op regionaal niveau dienen te worden opgesteld.

\section{DE TOEKOMST VAN RUBS ALS INFORMATIE-INSTRUMENT}

\section{Gebruiksdoelen en gebruikersgroepen}

De primaire doelstelling van het RUBS-project is het ontwikkelen van een meetinstrument op basis waarvan een continue monitoring kan plaatsvinden van de besteming van schoolverlaters. Daarbij staat de eerste besteming op de arbeidsmarkt centraal. Hierdoor kan een actueel beeld worden verkregen van de aansluiting tussen onderwijs en arbeidsmarkt voor de schoolverlaters, verbijzonderd naar opleidingstype en vakrichting. Diverse aspecten van de aansluitingsproblematiek kunnen daarbij worden belicht:

- relatieve omvang werkloosheid;

- relatie opleiding-beroep;

- bedrijfssectoren waar men werk vindt;

- wijze warop men aan een baan is gekomen;

- beloning;

- eventuele aanvullende scholing;

- 'kwalitatieve aansluitingsproblemen': beoordeling curriculum e.d. in het licht van de huidige werkzaamheden of vervolgopleiding.

Naast deze direct uit de RUBS-enquête afleidbare gegevens met betrekking tot de aansluiting tussen opleiding en werk kan de RUBS-enquête ook een uiterst belangrijk aanvullend databestand opleveren waarmee prognosemodellen voor arbeidsmarktontwikkelingen kunnen worden geschat en indicatoren voor de uitwijkmogelijkheden op de arbeidsmarkt, e.d. kunnen worden berekend. De RUBS-gegevens bieden op dit punt mogelijkheden voor zowel een verfijning naar opleidingstype/vakrichting, als een regionalisering van een informatiesysteem onderwijs-arbeidsmarkt, zoals dat bijvoorbeeld door het ROA in het kader van het Project Onderwijs en Arbeidsmarkt (POA) en het I-See! project is ontwikkeld. 
Langs bovengenoemde directe en indirecte weg kunnen de RUBS-gegevens een belangrijke informatiebron vormen voor de volgende gebruiksdoelen:

- het schoolmanagement;

- de studie- en beroepskeuzevoorlichting;

- het onderwijsbeleid;

- het arbeidsvoorzieningsbeleid;

- het personeelsbeleid c.q. Wervingsbeleid.

Schema A. Overzicht mogelijke informatleprodukten voor de verschillende gebruiksdoelen

Gebrutkersgroep

Gebruiksdoel

scholen

school decanen, arbeldsbureaus, LDC/RDC'S, beroepskeuze-adviseurs

Ministerle van Onderwijs en Wetenschappen, Provinciale on gemeentel Ijke overheden, onderwijsorgani saties

\section{CBA/RBA's}

Arbeldsbureaus

CVV's

Vrouw en werkwinkels, e.d.

bedrlffsleven, overheden, e.d.

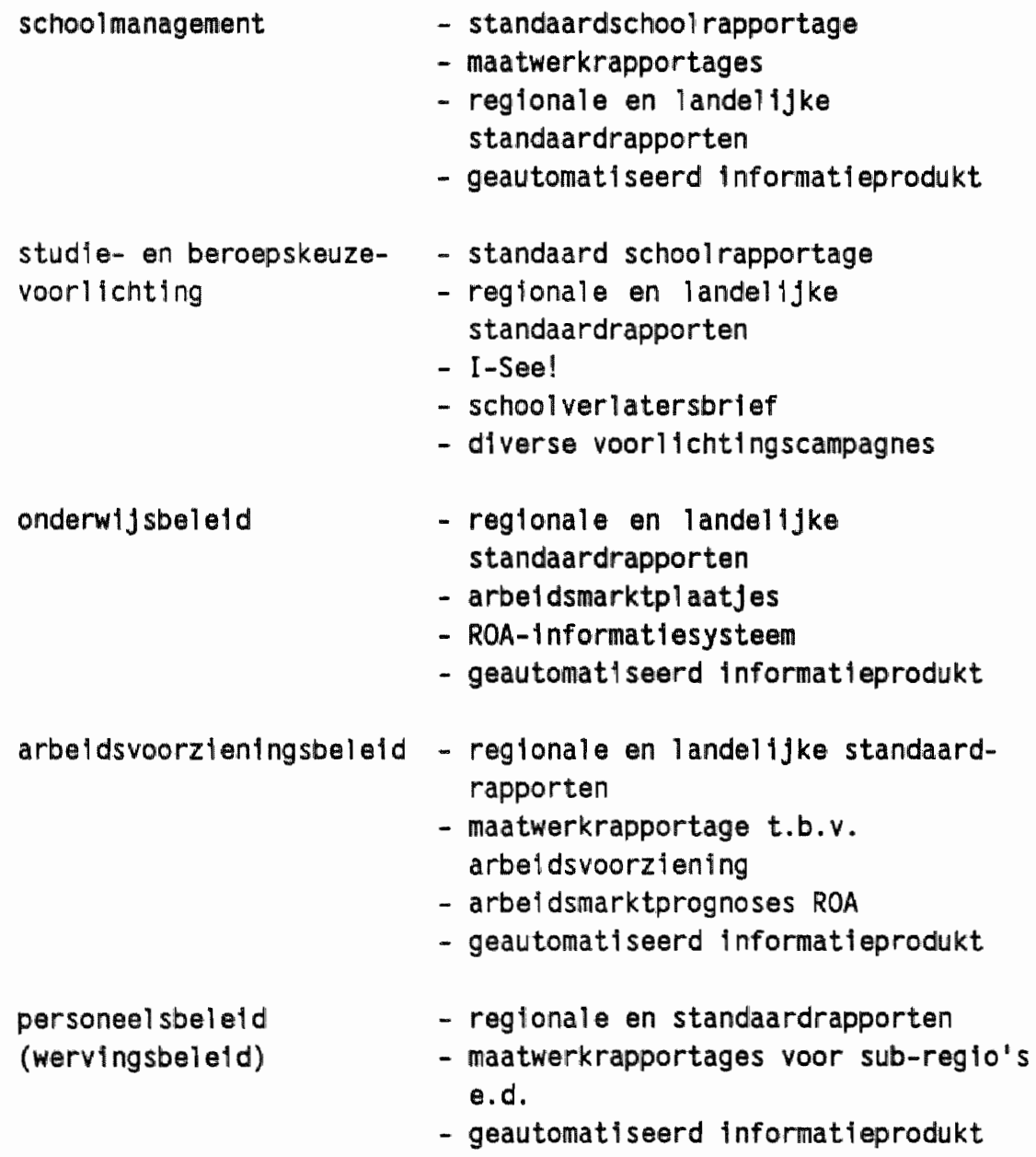

- geautomatiseerd informatieprodukt

In paragraaf 4.2. wordt uitvoerig ingegaan op de diverse (potentiële) gebruiksdoelen en gebruikersgroepen en op de informatieprodukten, waarmee op deze gebruiksdoelen kan worden ingespeeld. Schema $A$. geeft hiervan een globaal overzicht. 


\section{Onderzoekopzet}

Aivorens in te gaan op de algehele onderzoekopzet wordt eerst, op basis van de ervaringen van het pilotproject, een aantal voorstellen geformuleerd voor enkele onderzoektechnische en -organisatorische aspecten van het RUBSproject. Daarbij wordt achtereenvolgens de voorkeur uitgesproken voor een meting in de maand april, een jaarlijkse herhaalde meting, een aanvuliing van het eerste bestemmingsonderzoek met één of meer herhalingsenquêtes, het vooralsnog niet benaderen van de schoolverlaters van het Hoger Onderwijs, een schriftelijke enquêtering, het creëren van de mogelijkheid tot het stellen van aanvullende vragen aan deelpopulaties, en de noodzaak tot responsbewaking.

Voor wat betreft de algehele toekomstige onderzoekopzet wordt een drietal a) ternatieven geformuleerd:

1. Een landelijke steekproef onder de schoolverlaters.

2. Een integrale enquêtering van de schoolverlaters.

3. Een roterend panel van scholen, waarbij van de in een bepaald jaar in het onderzoek opgenomen scholen, alle schoolverlaters worden geënquêteerd.

Het eerstgenoemde voorstel, waarbij gedacht wordt aan een steekproef van circa 60.000 gediplomeerde en 36.000 ongediplomeerde schoolverlaters, heeft als belangrijk nadeel dat de resultaten op reglonal niveau slechts in beperkte mate naar opleidingstype kunnen worden gedifferentieerd. Daarentegen kan in deze opzet met een relatief eenvoudige organisatiestructuur worden volstaan.

De voorkeur gaat uit naar de twee laatstgenoemde alternatieven. Het roterend panel, dat gezien kan worden als een tussenvorm van de eerste twee alternatieven, impliceert een steekproef onder de diverse afdelingen van onderwijsinstellingen. Van de scholen die in een bepald jaar participeren zullen dan alle schoolverlaters van de desbetreffende afdelingen worden geënquêteerd.

Concreet zou dit kunnen betekenen dat in het beroepsonderwijs jaarlijks bij circa $50 \%$ van de (afdelingen van) scholen alle schoolverlaters van die scholen worden geënquêteerd. Daarentegen zouden in het Avo-onderwijs, 
waarvoor een verregaande differentiatie minder noodzakelijk is $c$, bij slechts $25 \%$ van de scholen de schoolverlaters worden geënquêteerd. Bij een roterend panelonderzoek betekent dit dat de instellingen voor beroepsonderwijs gemiddeld eenmal in de twee jaar en de AVO-scholen gemiddeld om de vier jaar in het onderzoek worden betrokken.

Een dergelijke opzet impliceert een jaarlijkse steekproefomvang van in totaal circa 110.000 - 150.000 gediplomeerde en circa 40.000 - 60.000 ongediplomeerde schoolverlaters. Tabel 5 geeft een overzicht van de samenstelling van de te benaderen populatie.

Bij de geconsulteerde beleidsinstanties op nationaal en regionaal niveau werd nogal eens de voorkeur uitgesproken voor het enquêteren van de totale groep van circa 400.000 schoolverlaters. Een dergelijke integrale benadering heeft vanzelfsprekend als voordeel dat een nauwkeurig beeld kan worden verkregen van de bestemming van de schoolverlaters. Zoals opgemerkt is het dan in principe mogelijk te verbijzonderen naar ruim 500 opleidingen c.q. vakrichtingen. Daarbij bestaat de mogelijkheid de data regionaal te verbijzonderen tot op RBA-niveau.

Tegenover bovengenoemde voordelen van een integrale aanpak staan als nadelen een overbelasting van het onderzoekveld en de aanzienlijk hogere kosten.

Ten opzichte van een roterend panel onder scholen heeft een integrale benadering als belangrijkste voordeel dat ieder jaar een beeld wordt verkregen van de bestemming van de schoolverlaters van iedere school. De integrale benadering en het roterende panel verschillen niet of nauwelijks ten aanzien van de mogelijkheid te verbijzonderen naar vakrichting en regio. Een integrale enquêtering heeft echter als voordeel dat de schooladministratie de aanlevering van de adressen van de schoolverlaters eerder als een reguliere activiteit beschouwt, waardoor problemen in de adresaanlevering zoals die tijdens het pilotproject naar voren kwamen, wellicht voorkomen kunnen worden.

Naast de geringere kosten heeft een roterend panel van scholen als voordeel ten opzichte van een integrale enquêtering dat het 'veldbederf' als gevolg van een overbelasting van het onderzoekveld geringer zal zijn.

c. Eventueel zou men bij de Avo-schoolverlaters kunnen differentiëren naar de aard van het gevolgde vakkenpakket. 
Desalniettemin zal ook bij dit alternatief de bereidheid van scholen om deel te nemen aan andere onderzoeken met betrekking tot de aansiuitingsproblematiek tussen onderwijs en arbeidsmarkt warschijnlijk afnemen. Daar staat echter tegenover dat de RUBS-enquête juist bedoeld is om enige uniformering aan te brengen in de lappendeken van ad hoc onderzoeken op dit terrein, die het onmogelijk makt de resultaten onderling te vergelijken en de aansiuitingsproblematiek bij schoolverlaters op continue basis te monitoren. Veel beter is het ons inziens om verschillende andere al of niet verwante vraagstellingen die men aan schoolverlaters zou willen voorleggen op ad hoc basis aan de vragenlijst toe te voegen. Een dergelijke aanpak wordt meestal aangeduid als 'piggy-backing'. Op deze wijze kunnen de voordelen van een landelijke uniformiteit gecombineerd worden met de voordelen van een regionale flexibiliteit. Naast het opnemen van aanvullende vragen kan deze regionale flexibiliteit overigens ook betrekking hebben op de regionale informatieverstrekking aan de verschillende doelgroepen in de regio.

\section{Toekomstige organisatiestructuur, begrote kosten en financiering}

Op basis van de ervaringen in het pilotproject kan worden geconcludeerd dat een groot aantal activiteiten op centraal niveau dient te worden verricht, om de in het pilotproject ondervonden nadelen van een te grote autonomie op regionaal niveau ten aanzien van de invuling van het RUBS-project te voorkomen. Eveneens zijn in het pilotproject de nadelen ondervonden van het inschakelen van de schooladministraties bij de verzending van de enquêteformulieren en de rappellering. In schema 4 in paragraaf 4.4.1. van het evaluatierapport wordt een overzicht gegeven van de gewenste afbakening van de te verrichten activiteiten tussen de landelijke organisatie, de regionale organisaties en de schooladministraties.

Een globale schatting van de jaarlijkse kosten van een toekomstige RUBSschoolverlatersenquête in de vorm van het voorgestelde roterende panel onder scholen komt uit op een bedrag van circa 4 miljoen gulden. De geschatte meerkosten van een integrale enquêtering bedragen circa 2 miljoen gulden. Deze bedragen vormen in feite de "bruto" kosten. Hier kunnen besparingen tegenover staan voor zover het RUBS-project de plaats inneemt van diverse ad hoc onderzoeken onder schoolverlaters met een soortgelijke vraagstelling of als de met het RUBS-project beoogde regionale en landelijke rapportages andere informatieprodukten overbodig maken. Op de begrote kosten zouden eveneens in mindering kunnen worden gebracht de kosten die zijn verbonden 
aan de in het kader van de uitvoering van de RUBS geplande activiteiten van met name de RDC's, voorzover deze activiteiten kunnen worden gezien als een concrete invulling van hun reguliere werkzaamheden.

Schema B. geeft tenslotte enkele kengetallen met betrekking tot de begrote kosten per te enquêteren schoolverlater.

Schema B. Kosten per te enquêteren schoolverlater: enkele kengetallen

kostenpost

kosten per te enquêteren schoolverlater

$\begin{array}{lc}\text { Personeelslasten op reglonaal niveau } & f \mathbf{5 , - \boldsymbol { * } ^ { * }} \\ \text { Kosten vragenl1jst, enveloppen e.d. } & \text { f } 0,25 \\ \text { Verzendkosten } & \text { f } 2,50 \\ \text { Data-invoer en codering } & \text { f } 1,25\end{array}$

Totale kosten bif roterend panel (ca. 200.000 schoolverlaters) f $20,--$

Totale kosten per extra te enquêteren schoolverlater $f 12,50$

* Deze kosten zijn slechts variabel bij een toe- of afname van circa 20.000 schoolverlaters.

Het Ministerie van Onderwijs en Wetenschappen en het Ministerie van Sociale Zaken en Werkgelegenheid en/of het Centraal Bestuur van de Arbeidsvoorziening (CBA) zullen het initiatief moeten nemen ten aanzien van de organisatorische inkadering van het voorgestelde centrale beheersorgaan, war de bestuurlijke verantwoordelijkheid zou moeten komen te liggen voor het RUBS-project.

Voor een eenduidige opzet van het RUBS-project is het van groot belang dat de afhankelijkheid van regionale financiers, zoals bij het pilotproject nog het geval was, wordt doorbroken door het basisproject landelijk te financieren. Weliswaar blijft het aanboren van regionale financieringsbronnen een reële optie wanneer het gaat om het stellen van aanvullende enquêtevragen of om het ontwikkelen van nieuwe produkten voor specifieke gebruikersgroepen in de eigen regio, maar voor de uitvoering van de voor het landelijke project minimaal noodzakelijke activiteiten dient de financiering op landelijk niveau plaats te vinden c.q. gecoördineerd te worden. Een dergelijke opzet 
maakt het mogelijk dat de bekostiging van de regionale activiteiten, in aansluiting op de regionale taakstelling, plaatsvindt vanuit het centrale beheersorgaan.

Geconcludeerd wordt dat het RUBS-project voor het overgrote deel gefinancierd zal dienen te worden vanuit de Ministeries van Onderwijs en Wetenschappen en Socjale Zaken en Werkgelegenheid en het CBA en/of de RBA's. Van het bedrijfsleven en de provinciale en gewestelijke overheden zouden op den duur aanvullende middelen moeten worden verkregen op basis van produktfinanciering.

Wanneer een positieve besluitvorming over voortzetting van het RUBS-project medio 1990 zou plaatsvinden, is het technisch gezien mogelijk om april 1991 op basis van de nieuwe opzet een enquête te houden onder de schoolverlaters van het schooljaar 1989/1990. Dit heeft als voordeel dat de continuyteit van het RUBS-project niet wordt doorbroken. Beide opdrachtgevers van het RUBSpilotproject zouden dan het voortouw moeten nemen bij de besluitvorming ten aanzien van de te volgen onderzoekvariant, de gewenste organisatiestructuur en de (voorlopige) financiering van het project. Voor de bij het RUBSpilotproject betrokken partijen als de COA's, de participerende scholen, arbeidsbureaus e.a. is een beslissing op korte termijn zeer gewenst. Indien een definitieve besluitvorming ten aanzien van de organisatie- en financieringsstructuur niet voor medio 1990 kan plaatsvinden, maar er in principe toch tot een voortzetting van het RUBS-project wordt besioten, is het van groot belang de voor de diverse betrokkenen noodzakelijke continuiteit te garanderen door het opzetten van een interimproject. 
1. INLEIDING

\subsection{Voorgeschiedenis}

In diverse Europese landen wordt al geruime tijd systematisch en grootschalig onderzoek verricht onder schoolverlaters en afgestudeerden. In Nederland is de gedachtenvorming over een systematische registratie van schoolverlaters pas een aantal jaren geleden op gang gekomen. Een belangrijke aanzet hiertoe vormde onder meer een studiedag van de Landelijke Comissie voor de Academische Studievoorlichting (LCAS) in november 1985, over het gebruik van arbeidsmarktgegevens bij de studie- en beroepskeuzevoorlichting (Hermans, 1985). In 1987 zocht de LCAS toenadering tot een aantal contactcentra Onderwijs-Arbeid (COA's) voor de uitvoering van een experiment met betrekking tot de systematische registratie van de uitstroom en bestemming van schoolverlaters. Naar de mening van de LCAS zou een dergelijke meting plats dienen te vinden op beperkte schaal en op korte termijn, uiterlijk een half jaar na het schoolverlaten. De COA's gaven daarentegen de voorkeur aan een grootschalige meting onder schoolverlaters, circa één jaar na het verlaten van de opleiding. Omdat men aanvankelijk niet tot overeensteming kon komen, liet de toekenning van de subsidie voor de landelijke coördinatie op zich wachten. Daarop zijn de betrokken vijf COA's op eigen initiatief in mei 1988 begonnen met een 'eerste-bestemingsenquête' onder circa 13.000 schoolverlaters.

De LCAS en de COA's hadden ondertussen in overleg een hernieuwd projectvoorstel geschreven, dat in januari 1988 verscheen onder de titel Registratie van de Uitstroom en de Besteming van Schoolverlaters, een samenwerkingsproject $\angle C A S / C O A ' s$. Het Instituut voor Onderwijsonderzoek (RION) van de Rijksuniversiteit Groningen zou daarbij zorg dragen voor de wetenschappelijke ondersteuning van het project. Op basis van het projectvoorstel is door de Ministeries van Onderwijs en Wetenschappen en Sociale Zaken en Werkgelegenheid een onderzoekopdracht verstrekt aan het Researchcentrum voor Onderwijs en Arbeidsmarkt (ROA) om voor de periode 1988/1989 de landelijke coördinatie van het voorgestelde project op zich te nemen. Na afloop van dit pilotonderzoek zou een uitgebreide evaluatie dienen plaats te vinden van de gevolgde werkwijzen, de toegepaste onderzoekmethoden en de voortgebrachte produkten. Tevens zouden daarbij aanbevelingen moeten worden gedaan voor een eventuele voortzetting van het project. Bij de opdrachtveriening speelde de opdracht van het Ministerie van Onderwijs en 
Wetenschappen aan het ROA om een informatiesysteem onderwijs-arbeidsmarkt te ontwikkelen, een belangrijke rol.

De tijd lijkt rijp te zijn voor een grootschalig systematisch onderzoek onder schoolverlaters. In de afgelopen jaren zijn daarvoor van verschillende kanten pleidooien gehouden en initiatieven genomen. Het recente verslag van de tafeironde van de Stichting Maatschappij en Onderneming (SMO) Het Nederlandse onderwijs als wapen in de internationale concurrentiestrijd (SMO, 1989), de nota Uitvoeringsplan sectorale kwaliteitszorg van de HBORaad (1989) en de Gids voor de externe kwaliteitszorg van de VSNU (1988) zijn hiervan duidelijke voorbeelden. Ook in de publicatie Marktgericht Beroepsonderwijs van de Vereniging Samenwerkende Landelijke Pedagogische Centra (LPC) uit 1989 wordt gepleit voor een regelmatig 'Regio-Behoeftenonderzoek' voor LBO-opleidingen. Het LPC wijst daarbij op het belang dat de resultaten van RUBS bij deze onderzoeken kunnen hebben.

Dat er al een groot aantal initiatieven is ontwikkeld voor onderzoek onder schoolverlaters en afgestudeerden blijkt, althans voor het hoger onderwijs, uit de daarop gerichte inventarisatie-studies van het ROA (Van Dam, De Grip en Heijke, 1988; Van Dam en Mortier, 1990). Om de onderlinge vergelijkbaarheld van de resultaten van onderzoek onder afgestudeerden naar de aansluiting tussen onderwijs en arbejdsmarkt te vergroten, is door het ROA een zogeheten 'arbeidsmarktscanner voor academici' ontwikkeld. (Van Dam, Heijke en Ramaekers, 1989). De RUBS-enquête kan worden beschouwd als een enigszins vergelijkbaar onderzoekinstrumentarium voor het voortgezet onderwijs.

\subsection{Het RUBS-pilotproject $1988 / 1989$}

In het eerder genoemde projectvoorstel "Registratie van de Uitstroom en de Besteming van Schoolverlaters, een samenwerkingsproject LCAS/COA'S"worden de belangrijkste doelstellingen en werkwijzen voor een pilotstudie naar de mogelijkheden voor een systematische registratie van schoolverlaters ten behoeve van de studie- en beroepskeuzevoorlichting genoemd. Als algemene doelstellingen van het RUBS-project op de lange termijn worden in het project-voorstel genoemd:

- Het beschikbaar maken van onderwijsuitstroom- en arbeidsmarktinstroomgegevens;

- Het in kaart brengen van het kwalificerend effect van opleidingen en het daarmee verminderen van de doorstroomproblematiek; 
- Het verschaffen van arbeidsmarktgegevens ten behoeve van studie- en beroepskeuzevoorlichters;

- Inzicht krijgen in de invloed van de regionale arbeidsmarkt op de arbeidsmarktpositie van schoolverlaters.

Volgens het rapport zijn de volgende positieve neveneffecten van het RUBSproject te verwachten:

- Het verkrijgen van inzicht in de problematiek AVO/LBO;

- Het bevorderen van de communicatie onderwijs-bedrijfsleven;

- Het verkrijgen van inzicht in de problematiek van het voortijdig schoolverlaten.

Hieruit wordt een drietal hoofddoelstellingen van de pilotstudie RUBS'89 afgeleid:

- Ontwikkelen van een landelijk bruikbaar meetinstrument ten behoeve van de registratie van de uitstroom van schoolverlaters en hun positie op de arbeidsmarkt;

- Ontwikkelen van een eenvoudig model voor de gegevensopslag en verwerking;

- Ontwikkelen van globale voorstellen voor landelijke en regionale vervolgprojecten.

Bij de opzet van het pilotproject is een opsplitsing gemaakt in een tweetal deelprojecten. Het eerste deelproject betreft een grootschalige enquête onder schoolverlaters voor het achterhalen van de "eerste besteming" van zowel ongediplomeerde als gediplomeerde schoolverlaters per opleidingsrichtingl. Door middel van deze enquête wordt tevens een aantal kwalitatieve gegevens verzameld over de aansluiting tussen opleiding en beroep. Dit deelproject is uitgevoerd door de COA's. Voor de wetenschappelijke ondersteuning van dit deel van het project is het (RION) ingeschakeld. Het RION heeft in dit kader zorg gedragen voor de ontwikkeling van de vragenlifst, het codeboek voor de dataverzameling, de opzet van de standaardrapportages op school- en regioniveau, een basisbestand van de landelijke data en een landelijke rapportage met betrekking tot het MDGO.

Het eerste deelproject is dus vooral bedoeld als een pilotstudie gericht op

1. Strikt genomen hoeft het hier niet om de eerste bestemming op de arbeidsmarkt te gaan. In het algemeen kan een meting in het eerste jaar na het schoolverlaten echter wel als een eerste-bestemmingsenquête worden getypeerd. 
het verzamelen van gegevens over de eerste besteming 2 van schoolverlaters op de arbeidsmarkt over de volle breedte van het voortgezet onderwijs. Het tweede deelproject is gericht op het ontwikkelen van een informatieinstrument dat een indicatie geeft van de omvang en de bestemming van het aanbod per opleidingsrichting op de arbeidsmarkt van gediplomeerde schoolverlaters op de middellange termijn. Deze informatie zou, volgens de LCAS, aan leerlingen, ouders en keuzebegeleiders een antwoord kunnen geven op de vraag hoe groot de kans op werk is na het behalen van het diploma van een bepaalde opleiding.

Voor het tweede deel van het RUBS-project zijn gegevens verzameld over de arbeidsmarktpositie van gediplomeerde schoolverlaters in de jaren $1986 \mathrm{t} / \mathrm{m}$ 1988. Deze gegevens zijn vervolgens geconfronteerd met gegevens over de instroom van leerlingen op dezelfde scholen in de periode $1982 \mathrm{t} / \mathrm{m} 1988$. De uitvoering van dit deelproject is verzorgd door het Centraal Orgaan van de Regionale Organen van het leerlingwezen (CORO) onder verantwoordelijkheid van de LCAS.

Het ROA heeft de coördinatie van beide deelprojecten op zich genomen en de zorg gedragen voor dit evaluerende eindrapport. Volgens de onderzoekopdracht dient in dit rapport ten minste aandacht geschonken te worden aan:

- het registratie-instrument: een beschrijving en analyse;

- de gevolgde methode bij het ontwikkelen van het registratie-instrument;

- de testresultaten van dit instrument;

- de hanteerbaarheid van het instrument, inclusief de beperkingen;

- de (tentatieve) resultaten van het gebruik van het instrument, gebrulkerservaringen, reacties van schoolverlaters, scholen/ dekanen;

- de gemeten c.q. verwachte effecten van het verschil in peildata;

- de follow-up van het project, naar inhoud, vorm en mogelijke financieringsbronnnen.

De projectcoördinatie heeft voor een belangrijk deel plaatsgevonden binnen een projectteam dat onder leiding stond van Dr. A. de Grip van het ROA. Contactpersonen van de verschillende bij de uitvoering van het pilotproject betrokken instanties (COA'S, CORO, LCAS, RION en ROA) makkten deel uit van dit projectteam (zie bijlage I).

2. In paragraaf 4.3.1. zal worden ingegaan op de mogelijkheid een eerste bestemingsonderzoek onder schoolverlaters aan te vulien met een of meerdere herhalingsenquêtes. 


\subsection{Indeling van het rapport}

De indeling van dit rapport is als volgt. Hoofdstuk 2 is geheel gewijd aan de eerste-bestemmingsenquête onder schoolverlaters, zoals deze medio 1989 door een elftal COA's is uitgevoerd met ondersteuning van het RION en het ROA. Achtereenvolgens komen de doelstellingen van dit deelproject, de onderzoekpopulatie en de gehanteerde vragenlijst aan de orde. Er wordt stil gestaan bij de verschillende aspecten van de uitvoering, zoals de voorbereiding van het onderzoek, de verzending en ontvangst van de vragenijjsten, het non-respons onderzoek en de codering en verwerking van de vragenlijsten. Vervolgens komen aan de orde de in het kader van het pilotproject ontwikkelde produkten in de vorm van diverse rapportages. Daarbij zal aandacht worden geschonken aan de ervaringen van de (eind)gebruikers van deze produkten.

Hoofdstuk 3 gat over het deelproject dat onder auspiciën van de LCAS is uitgevoerd door het CORO. Dit betreft de ontwikkeling van een model met betrekking tot het toekomstige aanbod van (gediplomeerde) schoolverlaters op de arbeidsmarkt en hun kans op werk dat aansluit op hun opleiding. Nadat kort is ingegaan op de doelstelling en opzet van het deelproject, worden kanttekeningen geplatst bij de opzet van dit deelproject en wordt het belang aangegeven van de resultaten die het gehanteerde model oplevert.

In hoofdstuk 4 wordt ingegaan op de toekomst van RUBS als informatieinstrument voor de aansluitingsproblematiek tussen onderwijs en arbeidsmarkt. Eerst wordt een aantal doelgroepen van RUBS beschreven en wordt ingegaan op de produkten waarmee in de verschillende gebruikersbehoeften zou kunnen worden voorzien. Daarna worden enkele technisch-inhoudelijke aspecten sumier besproken, waarna een drietal alternatieven met betrekking tot de toekomstige opzet van de RUBS-schoolverlatersenquête wordt uitgewerkt. Daarbij wordt de voorkeur uitgesproken voor twee van deze drie alternatieven. Uitgaande van dit 'voorkeursalternatief' wordt een globale schets gegeven van de mogelijke toekomstige organisatie- en financieringsstructuur van RUBS. 


\section{DE RUBS-ENQUETE VAN 1989}

\subsection{Inleiding}

De hoofddoelstelling van het eerste deelproject is het verkrijgen van actuele informatie over de besteming van schoolverlaters op de arbeidsmarkt. In de pilotstudie is daarom veel aandacht geschonken aan de opzet en uitvoering van een grootschalig eerste-bestemmingsonderzoek. Belangrijke aspecten daarvan vormen het ontwikkelen van het meetinstrument, de steekproeftrekking, de dataverzameling, de gegevensverwerking en de rapportage. Deze aspecten zullen hieronder uitvoerig worden besproken. Voorzover mogelijk zullen per onderwerp de doelstellingen wit het projectvoorstel worden aangegeven. Na een beschrijving van de in het proefjaar 1988 gevolgde werkwijze, volgt een weergave van de standpunten van de direct betrokkenen bij het RUBS-project en een evaluerende beschouwing. Hierbij doet zich het probleem voor dat de participerende COA's de toegezegde inventarisaties van de ervaringen van scholen met betrekking tot de uitvoering van het onderzoek en hun oordeel over de bruikbaarheid van de standaardrapportages wegens tijdgebrek nog niet hebben kunnen afronden. Derhalve moet worden volstaan met een summiere evaluatie op basis van een aantal door het ROA gevoerde gesprekken met betrokkenen en met potentiële gebruikersgroepen. De onderzoektechnische aspecten worden ook besproken in het RION-rapport Een onderzoeksontwerp voor het RUBS-project (Van Laarhoven 1990).

\subsection{Doelstelling van de RUBS-enquête 1989}

De belangrijkste doelstellingen van dit deelproject zijn:

1. De ontwikkeling van een instrument voor een jaarlijkse landelijke schoolverlatersenquête. Dit instrument omvat globaal gesproken een steekproefopzet van deelnemende scholen, een vragenlijst ten behoeve van de schoolverlaters en de software voor de verwerking en presentatie van de enquêteresultaten.

2. De (regionale) uitvoering en verwerking van de resultaten van de enquête onder schoolverlaters uit het schooljaar 1987/1988 over de volle breedte van het voortgezet onderwijs.

Ten aanzien van deze doelstellingen kunnen twee aanvullende opmerkingen worden gemaakt. Door de vijf COA's die reeds in 1988 een meting hadden verricht, was al het nodige voorwerk verricht op het gebied van de dataverzameling en 
-verwerking en de rapportage. Hierdoor kon gebruik worden gemaakt van reeds opgedane ervaringen. Anderzijds betekende dit echter dat men vanuit de noodzaak om regionale financieringsbronnen aan te boren, zich al op een aantal punten had moeten vastleggen tegenover de deelnemende scholen en de subsidiënten, waardoor het pilotkarakter van het project soms in het gedrang kwam.

Een tweede aanvullende opmerking betreft de deelnemende schooltypen. Op basis van de tweede doelstelling dienden alle schooltypen uit het reguliere voortgezet onderwijs in het pilotonderzoek vertegenwoordigd te zijn. Dit had als belangrijk voordeel dat alle mogelijke onderzoektechnische problemen met betrekking tot een specifiek opleidingstype in het pilotonderzoek naar voren kwamen. Dit laatste bleek in belangrijke mate realiseerbaar, andanks de diverse op regionaal niveau reeds aangegane verplichtingen. Daarnaast is het mogelijk gebleken in alle regio's het MDGO in het onderzoek op te nemen. Hierdoor is niet alleen de volle breedte van het voortgezet onderwijs in de RUBS-populatie aanwezig, maar één onderwijstype ook in de regionale diepte. Dit maakt het mogelijk om voor het MDGO een interregionale vergelijking te maken. Het MDGO fungeert daarmee als een concreet voorbeeld voor een landelijke rapportage die voor feder schooltype zou kunnen worden samengesteld, wanneer het RUBSproject in de toekomst het gehele Nederlandse voortgezette onderwijs zou bestrijken.

\subsection{De onderzoekpopulatie: definitie en steekproef}

Voor een afbakening van de onderzoekpopulatie is een precieze definiëring van het begrip 'schoolverlater' van belang. Overleg in de projectteamvergadering leidde tot de volgende omschrijving: 'iedere scholier die gedurende het schooljaar $1987 / 1988$ de opleiding heeft verlaten, met uitzondering van de schoolverlaters uit het eerste en tweede schooljaar lbo, mavo, havo en vwo'. Op basis van deze operationele definitie worden ook degenen die, al of niet met diploma, doorstromen naar een andere opleiding binnen dezelfde instelling (bijvoorbeeld van MAVO naar HAVO) tot de schooiverlaters gerekend. 'Herkansers', dat wil zeggen leerlingen die gezakt zijn voor het examen en het jaar over doen, vallen daarentegen buiten de onderzoekpopulatie. Schoolverlaters met één of meerdere deelcertificaten worden als gediplomeerden aangemerkt. Voortijdige, ongediplomeerde, schoolverlaters zijn eveneens door de school aangeschreven. Tot de laatstgenoemde categorie behoren ook de leerlingen die vanwege een verhuizing de school hebben verlaten. Op basis 
van de beschikbare gegevens is het niet mogelijk deze groep buiten de onderzoekpopulatie te houden.

Voor 1989 is besloten om af te zien van een steekproef, vanwege het feit dat de meeste COA's reeds hadden vastgelegd welke scholen benaderd zouden worden. In plaats daarvan is overgegaan tot een integrale benadering van alle schoolverlaters van de scholen die door de COA's bereid waren gevonden om mee te doen. De selectie van de schooltypen die in de verschillende regio's in het onderzoek zijn opgenomen, is in belangrijke mate bepald door de voorkeuren van de regionale financiers van het onderzoek. Dit heeft geleid tot sterk verschillende onderzoekpopulaties in de deelnemende regio's. Bovendien konden niet voor iedere regio representatieve gegevens voor de verschillende schooltypen worden voortgebracht.

Tijdens de pilotstudie is gezocht naar mogelijkheden om de resultaten van deze meting te herwegen of achteraf te corrigeren op basis van beschikbare CBS-gegevens. Hoewel dit in principe mogelijk moet zijn, is dit een kostbare en tijdsintensieve operatie. Vanwege het pilotkarakter van het landelijke onderzoek hoeft het niet representatief zijn van de uitkomsten niet als bezwaarlijk te worden beschouwd. Wel kan geconcludeerd worden dat de noodzaak om op regionaal niveau financieringsbronnen aan te boren ook in de toekomst een belangrijk knelpunt zou kunnen vormen voor een representatlef schoolverlatersonderzoek.

Uiteindelijk hebben er circa 255 scholen aan het RUBS-pilotproject meegedaan met in total circa 42.000 schoolverlaters. Tabel 1 geeft een overzicht van het aantal benaderde schoolverlaters per schoolsoort en regio.

\subsection{De vragenlijst}

De vragenlijst die in de pilotstudie is gehanteerd, werd samengesteld op basis van de vragenlijst die in de zomer van 88 mede op basis van adviezen van RION en ROA door enkele COA's is ontwikkeld. Deze vragenlijst werd op grond van de projectomschrijving voor RUBS' 89 door het RION verder ontwikkeld en is in de uiteindelijke vorm vastgesteld door het RUBS-projectteam. De vragenlijst diende volgens deze projectomschrijving in ieder geval te bevatten:

- achtergrondkenmerken: geboortejaar en -maand, geslacht, etnische herkomst, woonplaats;

- afstudeerrichting en diploma; 
- huidige bezigheid: studie, werk, werkloos, militaire dienst, vervolgstudie;

- in welke klas de school is verlaten.

En indien van toepassing:

- soort bedrijf, uitgeoefende funktie, beroep, dienstverband, inkomen, eventuele opleiding in het bedrijf;

- aansluiting van de schoolopleiding bij huidige werk c.q. vervolgopleiding;

- vervolgopleiding.

Tabel 1. Aantal aangeschreven schoolverlaters per schoolsoort en regio

\begin{tabular}{|c|c|c|c|c|c|c|}
\hline & IBO/LBO & Avo & $M D G 0^{*}$ & $\begin{array}{c}\text { overig } \\
\text { MBO }\end{array}$ & HBO & Totaal \\
\hline Friesland & - & - & 1230 & - & - & 1230 \\
\hline Groningen & - & - & 885 & - & - & 885 \\
\hline Drenthe & - & - & 867 & 694 & - & 1561 \\
\hline Overijssel & - & - & 1051 & - & - & 1051 \\
\hline Gelderl and & 1079 & 42 & 877 & 641 & - & 2639 \\
\hline Utrecht & - & - & 1524 & - & - & 1524 \\
\hline Noord-Holl land & 2432 & 233 & 2872 & 2274 & 421 & 8232 \\
\hline Zuld-Holl and Noord & 475 & 341 & 1524 & 2673 & - & 5013 \\
\hline Rijndel ta & 3152 & 2741 & 2025 & 574 & 673 & 9165 \\
\hline Zeel and & 1856 & 2749 & 470 & 553 & 539 & 6167 \\
\hline Flevoland & 1337 & 1385 & 98 & 905 & 41 & 3766 \\
\hline Totaal: & 10331 & 7491 & 13423 & 8314 & 1674 & 41233 \\
\hline
\end{tabular}

* inclusief intas en VHBO

Bron: diverse COA's

Deze reeks werd aangevuld met vragen over de arbeidsbemiddeling (bij werkende schoolverlaters), de wijze waarop naar (ander) werk is gezocht, of er aanvullend onderwijs wordt gevolgd en een open vraag voor aanvullende opmerkingen.

Met name over de vraagstelling voor de etnische herkomst is lange tijd 
gesproken. Na consultering van verschillende deskundigen is gekozen voor de 'thuistaal' als indicatie voor deze achtergrondvariabele. Uit een onderzoek onder enkele scholen in Flevoland en Noord-Holland is echter gebleken dat vee 1 allochtonen thuis Nederlands spreken, zodat deze vraagstelling niet voldoende onderscheidend is. Later zal hierop verder worden ingegaan.

Hoewel er ruimte bestond voor aanvullende vragen vanuit de regio of vanuit een individuele school, is hiervan uiteindelijk door geen van de COA's gebruik gemaakt. Van de vragenlijst zijn twee verschillende versies gemaakt, één voor het LBO/MAVO en één voor de overige schooltypen (MBO/KMBO/HAVO/VWO/HBO). Overigens verschillen deze vragenlijsten slechts op één punt. In de LBO/MAvO vragenlijst is gevraagd naar het niveau van de vakken waarin men eindexamen heeft gedaan. In de andere enquête is gevraagd naar de (eventuele) vooropleiding. Vanwege de tijdsdruk kon de vragenlijst niet voor gebruik worden getest.

Evaluatie van de gehanteerde vragenlijst:

Er is een drietal indicaties te geven van de kwaliteit van de vragenlijst:

- de mate van beantwoording (totale respons en respons per vraag);

- de kwaliteit van de beantwoording en de routing;

- de opmerkingen van de leerlingen op de vragenlijst.

De totale respons, circa $65 \%$, is gebruikelijk voor uitstroomonderzoek. Hieruit mag geconcludeerd worden dat de vragenlijst qua omvang en vormgeving geen negatieve invloed heeft gehad op de totale respons.

Het tweede punt dat wordt genoemd is de kwaliteit van de vraagstelling. Door de COA's Flevoland en Noord-Holland is, zoals reeds werd vermeld, onderzoek verricht naar de geschiktheid van de vraag over de etnische achtergrond van de schoolverlaters. On vragen naar de nationaliteit van de schoolverlaters of die van hun ouders te vermijden, is in dit verband gevraagd naar de thuis gesproken taal. De antwoorden op deze vraag zijn achteraf vergeleken met gegevens van de schooladministratie. De beantwoording van deze vraag blijkt bij beide COA's een onderschatting op te leveren van het aantal schoolverlaters afkomstig uit een etnische minderheid. Tabel 2 illustreert dit voor de provincie Flevoland. Maar liefst 21 van de 34 schoolverlaters die de school als allochtoon bestempelt, wordt op basis van de gehanteerde vraagstelling niet als dusdanig getypeerd. 
Tabel 2. Validiteit vraagstelling naar etnische minderheidsstatus schoolverlaters

antwoorden respondenten

administratie

Nederlands

Al lochtoon

school

Nederlands

498

3

Allochtoon

21

13

Bron: COA-Flevol and

De vraag naar het inkomen dat men verdient is nogal eens niet beantwoord. Waarschijnlijk heeft het feit dat ook de antwoordmogelijkheid "zeg ik liever niet" is opgenomen hiertoe bijgedragen. In hoeverre de representativiteit van de respons hierdoor in negatieve zin is beïnvloed, is niet op voorhand te zeggen.

Sommige respondenten, met name degenen die uitstroomden naar het leerlingwezen, hebben een verkeerde routing gekozen. In de meeste gevallen is het mogelijk geweest hiervoor bij de data-invoer te corrigeren.

Tenslotte geven ook de opmerkingen van de respondenten op de vragenlijst enige indicatie van de kwaliteit van de vragenlijst. Deze opmerkingen zijn door een aantal COA's op papier gezet. Hoewel er sprake is van een grote variëteit, komt een aantal reacties regelmatig terug. Met name de vraag naar diverse aspecten van de opleiding achteraf bezien (vraag 18), vindt een aantal respondenten onduidelijk of moeilijk te beantwoorden. Ook zijn er nogal eens opmerkingen gemaakt over de toegezegde anonimiteit in relatie tot het leerlingnumer en de adressering op naam.

Door de COA's is eveneens een groot aantal opmerkingen gemaakt over de diverse vragen. Bijlage IV geeft hiervan een overzicht. Daarnaast is een aantal algemene opmerkingen van belang. Enkele COA's maken melding van de behoefte bij sommige scholen om aanvullende vragen te kunnen stellen die specifiek betrekking hebben op de eigen school. Bij een aantal scholen bestaat er ook belangstelling voor een herhalingsenquête onder dezelfde populatie.

Als een mogelijkheid tot het stellen van aanvullende vragen werd bijvoorbeeld 
vanuit de Dienst Welzijn, Economie en Bestuur van de provincie Noord-Holland opgemerkt dat men graag meer zou willen weten over de arbeidsmarkt- en beroepenoriëntatie van werkzoekende schoolverlaters die werkloos zijn. Hiervoor moet de vraag naar de wijze waarop men naar werk zoekt worden aangevuld met vragen naar het beroep warin men zou willen werken en het gewenste aantal uren per week. Vervolgens zou de vraag over de wijze waarop naar (ander) werk is gezocht, uitgebreid kunnen worden (aantal sollicitaties, aantal gesprekken, redenen van afwijzing). Voor twee deelvragen (soort aanstelling, aantal werkzame uren) is een uitbreiding van het aantal antwoordmogelijkheden bepleit.

In gesprekken met betrokkenen en gebruikers van RUBS-produkten zijn verder geen opvallende wijzigingen voorgesteld. Wel is door enkele MDGO-directeuren benadrukt dat informatie over de etnische herkomst van leerlingen in de komende jaren voor het MBO belangrijker zal gaan worden, omdat de instroom van allochtonen in het $M B O$ in de komende jaren naar verwachting sterk zal gaan toenemen.

Voorlopige conclusie:

De opzet en de inhoud van de huidige vragenlijst voldoen in hoofdlijnen aan de gestelde doelstellingen. Voor enkele vragen is een aanpassing van de vraagstelling nodig. Het betreft dan vooral de vragen naar de etnische herkomst en de hoogte van het inkomen. Ook de routing en de verwijzing naar vervolgvragen zou op enkele punten nog verbeterd kunnen worden. Bij een aantal gesloten vragen zouden de antwoordmogelijkheden kunnen worden uitgebreid. Er moet worden nagegaan in hoeverre wensen met betrekking tot aanvullende vragen tot een uitbreiding van de standaardvragenlijst moeten leiden, of dat dergelijke vragen incidenteel op verzoek moeten worden toegevoegd aan de vragenlijst door bijvoorbeeld een inlegvel.

\subsection{Uitvoering van het onderzoek}

2.5.1. Organisatie van de dataverzameling

De dataverzameling van het pilotproject is in handen geweest van de COA's, met een belangrijke rol voor de deelnemende scholen, die de verzending van de vragenlijsten hebben verzorgd. Hoewel er, vanwege het pilotkarakter van 
het onderzoek, is gezocht naar een COA die de verzending zelf op zich wilde nemen, zijn uiteindelijk alle vragenlijsten door de scholen zelf verstuurd.

In het najaar van 1988 is begonnen met de voorbereidingen van de enquête. Er werd overeensteming bereikt tussen het ROA en het RION en tussen het ROA en de COA's over respectievelijk de opdrachtverlening en de samenwerkingsovereenkomst en het bijbehorende werkplan. Vervolgens werd een werkplan opgesteld en werden door de COA's contacten gelegd en samenwerkingsovereenkomsten gesloten met de deelnemende scholen. Het opgestelde werkplan werd door de diverse aan het project deelnemende partijen geaccordeerd. Dit werkplan bestaat uit een takkverdeling en een tijdsplanning van het pilotproject (zie Bijlage $V$ ). De gevolgde procedures ten aanzien van administratie, verwerking, ontvangst en registratie van de vragenlijsten zijn weergegeven in schema $I$.

Nadat een school zich bereid had verklaard in het RUBS-pllotproject deel te nemen, werd door de school het aantal schoolverlaters per richting opgegeven, opgesplitst in gediplomeerden en ongediplomeerden. De laatste gegevens zijn van belang voor de 'aanmaak' van de leerlingnummers op de achterzijde van de vragenlijsten. Dit leerlingnumer is ontwikkeld om anonieme verzending door de scholen mogelijk te maken. Het bestaat uit 16 posities:

- de eerste twee posities geven de regio aan en hebben betrekking op het COROP-gebted;

- het derde cijfer geeft aan welke zending het betreft;

- het vierde, vijfde en zesde cijfer bevat het schoolnumer;

- de zevende tot en met twaalfde positie geeft de opleidingsrichting aan, op 6 digit niveau gecodeerd volgens de door het RION ontwikkelde classificatie van opleidingen;

- de dertiende positie geeft aan of de schoolverlater de school mét of zonder diploma heeft verlaten;

- de veertiende tot en met zestiende positie is gereserveerd voor een leerlingnumer per school.

De bovengenoemde classificatie van opleidingen vormt een zo compleet en nauwkeurig mogelijk overzicht van alle aan RUBS deelnemende opleidingen, vakrichtingen en differentiaties. Het opstellen van een dergelijke nieuwe classificatie was noodzakelijk omdat de Standaard Onderwijs Indeling (SOI) van het CBS te grofmazig is voor de gewenste differentatie naar vakrichting. We 1 is er uitarukkelijk voor gezorgd dat de classificatie eenduidig koppelbaar is aan de SOI. Na een mondelinge of schriftelijke instructie van (doorgaans) de 
schooladministratie door het COA met behulp van de landelijk ontwikkelde handleiding, werden de genummerde vragenlijsten met retour-enveloppen bij de circa 250 deelnemende scholen afgeleverd. Deze hebben de vragenlijsten verzonden naar in total circa 42.000 schoolverlaters uit het schooljaar 1987/88. De vragenlijsten waren vergezeld van een begeleidend schrijven van de school.

De antwoordenveloppe werd gericht aan het adres van het COA. Daar zijn de nummers van de geretourneerde vragenlijsten ingevoerd in een door het COA Noord-Holland ontwikkeld registratieprograma, zodat op ieder gewenst ogenblik 'de stand' van de respons per school en richting kon worden nagegaan.

In de loop van de maand mei begonnen de vragenlijsten binnen te komen en werd een rappelleringsbrief verzonden. De vragenlijsten bleven tot eind juni binnen komen. Door het RION werd inmiddels gewerkt aan de opzet voor de standaardrapportage.

Schema I Overzicht van gevolgde procedures ten aanzien van administratle, verzending, ontvangst en registratie van de vragenlijsten

\begin{tabular}{|c|c|c|}
\hline stap 0 & $\begin{array}{c}\mathrm{COA} \\
\downarrow\end{array}$ & - instructio administratio schoien. \\
\hline stap 1. & $\begin{array}{c}\text { deel nemende school: } \\
\downarrow\end{array}$ & - opgave aantallen schoolverlaters per rlchting. \\
\hline stap 2. & COA: & $\begin{array}{l}\text { - aanmaak leerlingnummers en vragenlijsten; } \\
\text { - administratie van aantallen en nummers van } \\
\text { vragenlijsten per school en richting, gesplitst } \\
\text { naar gediplomeerden en ongediplomeerden; } \\
\text { - instructie van schooladninistratle; } \\
\text { - verzending vragenlijsten naar scholen. }\end{array}$ \\
\hline stap 3 . & $\begin{array}{c}\text { deelnemende school: } \\
\downarrow\end{array}$ & - verzending vragenlifjsten naar schoolverlaters. \\
\hline stap 4 . & $\begin{array}{l}\mathrm{COA} \\
\downarrow\end{array}$ & $\begin{array}{l}\text { - ontvangst van geretourneerde vragenlijsten; } \\
\text { - reglstratie van respons; } \\
\text { - twee weken na stap } 3 \text { : verzending van } \\
\text { rappelbrief naar scholen. }\end{array}$ \\
\hline stap 5. & deelnemende school: & $\begin{array}{l}\text { - selectle van de non-respons op basis van } \\
\text { responsgegevens van het COA; } \\
\text { - verzending rappelbrlef naar non-respons; } \\
\text { - ontvangst van onbestelbare vragenlijsten. }\end{array}$ \\
\hline stap 6 . & $\mathrm{COA}$ & $\begin{array}{l}\text { - ontvangst van geretourneerde vragenlijsten; } \\
\text { - registratie van respons; } \\
\text { - vaststellen van non-respons op bas } 1 \text { s van } \\
\text { gegevens van de school; } \\
\text { - verzenden vragenl1jsten naar dataverwerkings- } \\
\text { bureau. }\end{array}$ \\
\hline
\end{tabular}


Evaluatie van de gevolgde werkwijze:

$\mathrm{Er}$ is voor de hierboven beschreven werkwijze, die grofweg neerkomt op voorbereiding en verzending door de scholen en ontvangst en registratie door de COA's, gekozen op basis van de verwachting dat dit:

- de anonimiteit van de schoolverlaters zou waarborgen;

- de respons zou verhogen;

- de bereidheid van scholen om mee te doen zou vergroten;

- het contact tussen COA en school zou bevorderen.

Ten aanzien van het eerste punt kan worden opgemerkt dat enkele schoolverlaters in verwarring zijn gebracht door de toegezegde anonimiteit. Dikwijls zijn, soms niet ingevulde, vragenlijsten retour gekomen met opmerkingen daaromtrent in de kantijjn. Ook zijn in een aantal gevallen de leerlingnummers van het vragenformulier verwijderd, waardoor het enquête-formulier onbruikbaar werd.

Er zijn vanuit het pilotproject geen aanwijzingen gevonden voor de stelling dat de respons groter is vanwege de expliciet toegezegde anonimiteit. Ook zijn er geen directe aanwijzingen dat de bereidheid tot deelname van scholen als gevolg van deze expliciete toezegging is toegenomen. Enkele COA's melden dat scholen zich hebben teruggetrokken vanwege de grote hoeveelheid werk die de deelname met zich mee bleek te brengen voor de schooladministratie. Uit de onder de COA's verrichte evaluatie is gebleken dat veel scholen klagen over deze grote hoeveelheid werk. Bij de COA's bestaat echter wel de verwachting dat de huidige werkwijze, na de aanvangs- en aanpassingsmoeilijkheden uit het eerste jaar, in de komende jaren aanzienlijk versoepeld zal worden. Zeker als een schooladministratie helemal is ingesteld op een frequente deelname aan RUBS.

Overigens wordt het gebruik van een leerlingnumer bestaande uit 16 cijfers, vooral door de scholen mar ook door de COA's als erg omslachtig ervaren. De suggestie werd gedaan dat bij een meer centrale registratie, verzending en ontvangst van de vragenlijsten dit codenummer mogelijk vervangen zou kunnen worden door een optisch leesbare streepjescode.

Als nadelen van de verzending door de scholen worden door de COA's onder andere genoemd:

- onjuiste doorgifte van aantallen schoolverlaters met en zonder diploma;

- niet gelijktijdige verzending van de vragenlijsten; 
- zware belasting van schooladministraties;

- fouten in de registratie door gebrekkige communicatie tussen schooldirectie en schooladministratie;

- in een aantal gevallen ontbreken van rappellering, mede vanwege de kosten.

Het eerstgenoemde punt veroorzaakte vooral problemen bij de afbakening van de populatie van ongediplomeerden: door administratieve lacunes of een gering enthousiasme van scholen voor onderzoek onder hun uitvallers werden dikwijls veel minder ongediplomeerden schoolverlaters opgegeven dan op grond van andere cijfers aanwezig moesten worden geacht. (Zie ook Van Laarhoven en Waslander 1990).

Er kan dus worden geconcludeerd dat er in het pilotproject duidelijke twijfels zijn ontstaan ten aanzien van het inschakelen van de schooladministratie bij het verzenden van de vragenlijsten en de rappellering. Om die reden zullen de vragenlijsten in 1990 op grote schaal door de COA's zelf worden verzonden, waarbij er dan met name voor gewaakt moet worden dat alle ongediplomeerde schoolverlaters ook daadwerkelijk in de steekproefpopulatie worden betrokken. Daarbij is wel gebleken dat er een overigens beperkt aantal scholen niet bereid is om adressen van schoolverlaters uit handen te geven.

\subsubsection{Respons en non-respons onderzoek}

De waarde van de resultaten van de RUBS schoolverlatersenquête is in belangrijke mate afhankelijk van de representativiteft van de uitkomsten. Van Laarhoven (1990) makt daarbij een onderscheid tussen de hoogte van de respons en de selectiviteit van de non-respons.

Tabel 3 geeft een beeld van de hoogte van de totale respons. In zijn algemeenheid kan worden gesteld dat het gemiddelde responspercentage van 65 als bevredigend kan worden beschouwd. Op basis van gegevens van het COA NoordHolland is in tabel 4 een overzicht samengesteld van de respons naar diplomabezit en na rappellering. Laatstgenoemde tabel makt twee dingen duidelijk. Ten eerste is de respons onder gediplomeerden (69\%) veel groter dan onder ongediplomeerden (42\%). Bovendien blijkt de rappellering erg belangrijk te zijn. Bijna een kwart (24\%) van de benaderde schoolverlaters respondeert pas nádat een rappè 1 is verzonden. 
Tabel 3. Responspercentage per schoolsoort en reglo (totale populatie)

\begin{tabular}{lcccccc}
\hline & IBO/LBO & AVO & MDGO & $\begin{array}{c}\text { overig } \\
\text { MBO }\end{array}$ & HBO & Totaal \\
\hline Friesland & - & - & 66 & - & - & 66 \\
Groningen & - & - & 65 & - & - & 65 \\
Drenthe & - & - & 79 & 80 & - & 79 \\
Overifssel & - & - & 73 & - & - & 73 \\
Gelderland & 66 & 71 & 81 & 67 & - & 71 \\
Utrecht & - & - & 64 & - & - & 64 \\
Noord-Hol land & 66 & 61 & 63 & 54 & 65 & 62 \\
Zuid-Holl and Noord & 54 & 79 & 59 & 59 & - & 60 \\
Rijndel ta & 58 & 67 & 69 & 61 & 55 & 63 \\
Zeeland & 66 & 66 & 73 & 81 & 58 & 67 \\
Flevol and & 63 & 71 & 76 & 54 & 73 & 64 \\
& & & & & & 65 \\
Totaal : & 63 & 68 & 69 & 61 & 59 & \\
\hline
\end{tabular}

Bron: diverse COA's

Tabe1 4. Respons Noord-Holland, na eerste aanschrijuing en na rappellering

\begin{tabular}{lccccccc}
\hline Alle scholen & uitgezet & \multicolumn{2}{c}{$\begin{array}{c}\text { respons na } \\
\text { aanschrijuing }\end{array}$} & $\begin{array}{c}\text { respons } \\
\text { rappèi }\end{array}$ & & \multicolumn{2}{c}{ non-respons } \\
& & $\mathrm{N}$ & $\%$ & $\mathrm{~N}$ & $\%$ & $\mathrm{~N}$ & $\%$ \\
met diploma & 6.016 & 2.630 & 44 & 4.169 & 69 & 1.847 & 31 \\
Zonder diploma & 1.937 & 430 & 22 & 811 & 42 & 1.126 & 58 \\
deelcertificaat & 279 & 53 & 19 & 85 & 30 & 194 & 70 \\
Totaal & 8.232 & 3.113 & 38 & 5.065 & 62 & 3.167 & 38 \\
$\mathrm{~N}=$ aantal & & & & & & & \\
\hline
\end{tabular}

Bron: COA Noord-Holland

$\mathrm{Nu}$ geconstateerd is dat de non-respons onder ongedjplomeerden beduidend groter is dan onder gediplomeerden, rijst de vraag of er ook sprake is van selectiviteit van de non-respons. Om dit vast te stellen is door een aantal COA's 
een non-respons onderzoek uitgevoerd met behulp van een door het RION ontwikkelde procedure en vragenlijst. Deze vragenlijst is als Bijlage VII aan dit rapport toegevoegd. Bij het non-respons onderzoek is gebruik gemaakt van de 'methode van de centrale vraag'. Deze methode houdt in dat de contrôle op de kwaliteit van de respons zich beperkt tot de belangrijkste vraag uit het onderzoek. Bij RUBS betreft dit de vraag naar de huidige bezigheid.

Het non-respons onderzoek bestond wit een telefonische enquête onder gediplomeerde- en ongediplomeerde schoolverlaters die 'bij het sluiten van de brievenbus' in de COA-administratie als non-respondent geboekt stonden. De resultaten van het non-respons onderzoek waren door de geringe omvang van het non-respons onderzoek niet bruikbaar genoeg voor een herweging van de eerste onderzoekresultaten. Om die reden is er van af gezien om de enquêteresultaten te herwegen. In plaats daarvan is besloten dat de COA's, voor zover een non-respons analyse werd uitgevoerd, zouden volstaan met het vermelden van de resultaten van het non-respons onderzoek in de regionale rapportage. Wanneer dit nodig bleek te zijn, zou dit worden aangevuld met een kanttekening ten aanzien van de representativiteit van de uitkomsten.

Bij zorgvuldige beschouwing van de responspercentages en de resultaten van het non-respons onderzoek onder de schoolverlaters van de MDGO-scholen in de drie noordelijke provincies kan het volgende worden vastgesteld (Waslander en Van Laarhoven, 1990):

- de non-respons onder ongediplomeerden is significant hoger dan onder gediplomeerden;

- bij de gediplomeerden is het aandeel van de werkenden vrijwel gelijk in de respons - en de non-responsgroep. De resultaten van RUBS zijn voor deze groep derhalve representatief. Gediplomeerden die bezig zijn met een vervolgopleiding reageren echter aanmerkelijk vaker dan gediplomeerden die zijn gaan werken;

- ook bij de ongediplomeerden is het aandeel van de werkenden bij de responsen non-responsgroep ongeveer even groot. Het aandeel van de werklozen is in de non-responsgroep echter significant groter, en het percentage dat een vervolgopleiding heeft gekozen significant kleiner, dan in de responsgroep. De enquête-uitkomsten leveren derhalve voor het MDGO in de drie noordelijke provincies een onderschatting op van het percentage werkloze ongediplomeerde schoolverlaters en een overschatting van het percentage ongediplomeerde schoolverlaters dat aan een vervolgopleiding is begonnen. Voor de gediplomeerde schoolverlaters en de werkende ongediplomeerde schoolverlaters zijn de 
onderzoekuitkomsten echter representatief.

Ook het non-respons onderzoek in Noord-Holland heeft geleid tot de conclusie dat er bij de schoolverlaters uit het MDGO significante verschillen bestaan tussen de respons en de non-respons van gediplomeerden en ongediplomeerden. Een dergelijk verschil kon echter niet worden geconstateerd voor schoolverlaters uit het LBO, het AVO en het MTO.

COA Flevoland heeft een non-respons onderzoek verricht onder de gediplomeerde schoolverlaters uit het IBO/LBO en het MAVO. Bij het IBO/LBO werden geen significante verschillen aangetroffen in de huidige bezigheid van responderende- en niet-responderende (gediplomeerde) schoolverlaters. Het nonrespons onderzoek onder 49 niet-responderende MAVO-leerlingen met een diploma leverde daarentegen wél significante verschillen op met betrekking tot de huidige bezigheid van de responsgroep. Op basis hiervan heeft COA-Flevoland besloten de onderzoekresultaten van de MAVO-schoolverlaters te herwegen.

Met betrekking tot de representativiteit van de RUBS-resultaten kan geconcludeerd worden dat wellicht de resultaten van ongediplomeerde schoolverlaters een correctie behoeven. Vooralsnog is er echter weinig patroon in de selectiviteit in de non-respons te ontdekken. Voor de gediplomeerden is de nonrespons in het algemeen representatief te noemen. Ook moet geconcludeerd worden dat bij een voortzetting van het RUBS-project een non-respons analyse niet mag ontbreken.

\subsubsection{Codering en verwerking}

De COA's zijn eind mei 1989 begonnen met het doorzenden van de geretourneerde vragenlijsten naar het marktonderzoek en dataverwerkingsbureau DESAN te Amsterdam voor de codering van de open vragen en de data-entry van de antwoorden. Nadat aanvankelijk door het projectteam was besloten om de 'probleemgevalien' bij het coderen van de beroepen zelf te coderen, bleek dat DESAN, mede door verbetering van de programmatuur, slechts enkele tientallen probleemgevallen had. Deze zijn toen door het ROA gecodeerd.

$\mathrm{Er}$ is naar gestreefd de fouten in de data-invoer te minimaliseren door het leerlingnumer en de antwoorden op enkele cruciale vragen dubbel te coderen. Daarnaast zijn er ook zgn. 'range- en rule checks' en 'skip-and-fill rules' toegepast bij de data-invoer. 
Bij de classificatie van de antwoorden op de open vragen naar beroep en bedrijfstak is gebruik gemaakt van de standaardclassificaties van het CBS voor beroepen (Beroepenclassificatie 1984) en bedrijfstakken (Standaard Bedrijfs Indeling 1974). Bij zowel de beroepen-als de bedrijfstaktypering heeft de codering plaatsgevonden op basis van de 4-cijfercode. Dit lage aggregatieniveau makt het mogelijk de uitkomsten, indien dat nodig is, in verregaande mate te verfijnen. Voor de classificatie van de gevolgde opleidingen is, zoals reeds is opgemerkt, gebruik gemakt van de door het RION vastgestelde 6-cijfercode van opleidingen c.q. vakrichtingen. Dezelfde lijst is later gebruikt voor de samenstelling van de kolomhoofden (labels) in de tabellen en grafieken. Daarentegen heeft de codering van de vragen naar de eventuele voor- en vervolgopleiding plaats gevonden op basis van de Standaard Onderwijs Indeling 1978 van het CBS. Daarbij is gecodeerd op basis van de 5-cijfercode.

Voor de codering van de antwoorden op de vraag of men nog een (andere) cursus, training of part-time opleiding volgt, is (nog) geen geschikte classificatie voorhanden. Daarom is bij de verwerking van deze vraag vooralsnog volstaan met een opsoming van de gegeven antwoorden. Deze 'listing' zou als basis kunnen dienen voor een nieuwe classificatie van het gevolgde aanvullende onderwijs, die in de toekomst gebruikt zou kunnen worden.

DESAN was eind juli 1989 gereed met de data-invoer van de 22.602 geretourneerde vragenlijsten. Na de zomervakantie werd begonnen met de produktie van de tabellen en grafieken volgens de daartoe gegeven aanwijzingen van het RION. COA Zeeland heeft nòch bij de codering nòch bij de produktie van de tabellen en grafieken gebruik gemaakt van DESAN, maar deze taken uitbesteed aan het Provinciaal Opbouw Orgaan Zeeland. Daarbij is wel gebruik gemaakt van de schriftelijke richtijinen die het RION voor DESAN heeft opgesteld.

Evaluatie van de gevolgde werkwijze:

De keuze voor het verwerkingsbureau DESAN is in eerste instantie vooral gebaseerd geweest op de relatief geringe prijs en de snelle levertijd. De kwaliteit var de codering van de open vragen ter vaststelling van het uitgeoefende beroep, leek in 1988 vrij matig te zijn geweest. Bij een nieuwe contrôle op de kwaliteit bleek deze in 1989 echter aanzienlijk te zijn toegenomen. In bijna $8 \%$ ( 9 gevallen) van de 116 contrôle-cases bleek door DESAN op 4-cijferniveau een andere beroepencode te zijn toegekend dan door 
een van de vier contrôleurs was gedaan. Geen van de contrôleurs heeft een geringere afwijking gehald.

Het verzorgen van de data-invoer en -verwerking op regionaal niveau, zoais in het pllotproject is gebeurd voor de provincie Zeeland, blijkt duidelijk inefficiënt te zijn, onder meer vanwege de in dat geval noodzakelijke communicatiestromen, de afstemingsproblemen en de fouten die dit met zich mee brengt. In de toekomst zullen data-invoer en -verwerking dan ook bij voorkeur door een en dezelfde instelling centraal moeten plaatsvinden.

Bij voortzetting van het RUBS-project verdient het aanbeveling om ook bij het coderen van de vragen naar de voor- en vervolgopleiding niet de Standaard Onderwijs Indeling (SOI) van het CBS te gebruiken, maar gebruik te maken van de in het kader van het RUBS-project ontwikkelde classificatie van opleidingen, omdat de SOI niet verfijnd genoeg is om een beeld te kunnen krijgen van de gevolgde vakrichting. De koppelbaarheid van de RUBS-uitkomsten met andere gegevensbestanden blijft daarbij, zoals reeds eerder is opgemerkt, gehandhaafd.

Met de Hoofdafdelingen Statistieken van Arbeid en Lonen en Persoons- en Gezinsenquêtes van het CBS is in juni 1989 een oriënterend overleg gevoerd om te achterhalen of ervaren typeurs en codeurs van het CBS in de komende jaren zouden kunnen worden ingeschakeld voor de verwerking van de vragenlijsten. Helaas bleken daarvoor geen mogelijkheden te zijn. Door de hoge kosten en capaciteitsproblemen zullen er bij het CBS ook weinig mogelijkheden zijn voor andere vormen van samenwerking bij de dataverwerking. Samenwerking zou er overigens warschijnlijk toe leiden dat de onderzoekuitkomsten slechts met een aanzienlijke vertraging naar buiten zouden kunnen worden gebracht.

Gebleken is dat het onderbrengen van de data-invoer bij een marktonderzoekbureau het mogelijk maakt relatief snel met de gegevens naar buiten te komen. Bovendien is een marktonderzoekbureau ook vanuit kostenoogpunt een acceptabele optie. Het marktonderzoekbureau DESAN heeft bovendien de afgelopen twee jaar waardevolle expertise ontwikkeld met betrekking tot de data-invoer van een schoolverlatersenquête en is in staat ook grotere aantal len enquêteformulieren te verwerken dan voor het pilotproject is gebeurd.

Wat betreft de verwerking van de data tot standaardtabellen is gebleken dat het uitbesteden van deze taak aan een marktonderzoekbureau, dat niet zelf zorg 
draagt voor de school-en regionale rapportages, problemen met zich mee kan brengen. Deze problemen betreffen de noodzaak om op basis van proefuitdraaten beslissingen te kunnen nemen over de uiteindelijke vorm waarin de resultaten worden gepresenteerd. Dit probleem heeft zich in het afgelopen jaar vooral voorgedaan bij de omzetting van de ruwe uitdraaien van de beroepen waarin de schoolverlaters van een bepaald opleidingstype werkzaam zijn, in meer overzichtelijke tabellen. Hierbij worden beroepscategorieën waarin relatief veel schoolverlaters werkzaam zijn in verregaande mate verbijzonderd, terwijl beroepen waarin slechts een enkele leerling werkzaam blijkt te zijn, worden samengevoegd tot een hoger aggregatieniveau. Hieruit moet worden geconcludeerd dat de uiteindelijk te presenteren tabellen verzargd moeten worden door de instelling die ook de rapportage samenstelt. Deze moet dan wel kunnen beschikken over de benodigde hard-en software en expertise.

\subsection{Rapportage}

In de totale onderzoekcyclus van RUBS' 89 is er relatief veel inspanning gaan zitten in het ontwikkelen van onderling vergelijkbare rapportages. Daarbij kan achtereenvolgens onderscheid gemaakt worden in de produktie van de tabellen en grafieken, het samenstellen van de analyses en rapporten en tenslotte aan de oplevering van de rapporten en de implementatie van de onderzoekresultaten bij de regionale opdrachtgevers en belanghebbenden. In deze paragraaf zal op deze drie groepen van activiteiten achtereenvolgens worden ingegaan.

Bij de ontwikkeling van de tabellen en grafieken van RUBS'89 zijn de tabellen en grafieken van RUBS'88 in principe als uitgangspunt genomen. Deze waren echter op verschillende plaatsen voor verbetering vatbaar. Bovendien werd een aantal veranderingen noodzakelijk door de veranderingen in de vragenlijst. Daarnaast speelden verschillende programmatuurtechnische- en budgettaire beperkingen een rol. Gedurende het ontwikkelingsproces bleek vooral het 'bulkkarakter' van het opleveren van grote aantallen standaardtabellen, met name op schoolniveau, een belangrijke beperking te betekenen voor de honorering van specifieke wensen over de opzet van de tabel van bepaalde schooltypen.

In beginsel zou over alle variabelen uit de vragenlijst kunnen worden gerapporteerd, als voor een aantal variabelen een indikking en aftopping zou worden aangebracht om de inzichtelijkheid te vergroten. In een aantal gevallen werden categorieën van variabelen samengevoegd om een aanvaardbare celvulling te 
bereiken. Hierbij diende er voor gezorgd te worden dat een aantal belangrijke verschillen, bijvoorbeeld tussen gediplomeerden en ongediplomeerden, voldoende zichtbaar bleef. De eerder genoemde beperkingen leidden tot de keuze voor een vaste set 'standaardtabellen' (twee-en drie-dimensionaal) en tweedimensionale gestapelde staafdiagramen.

Nadat deze uitgangspunten in het projectteam waren besproken, werd uitvoerig stilgestaan bij de inhoudelijke keuzen van de tabellen en grafieken. Daarbij werd onderscheid gemaakt tussen de rapportage op schoolniveau en de regionale rapporten voor de diverse schooltypen.

Voor de standaardrapportage op schoolniveau werd gekozen voor 12 kruistabellen (twee- of driedimensionaal) en 2 staafdiagrammen per school. Door de meeste COA's is daarnaast om een tabel met een overzicht van de respons gevraagd. Voor iedere standaardrapportage van schooltypen op regionaal niveau werden in totaal 30 tabellen en 6 grafieken gemaakt.

Door DESAN werden vervolgens verschillende proefuitdraaien gemaakt, die in eerste instantie door het hele projectteam werden besproken, doch al spoedig door een kleiner groepje. Dankzij deze proefuitdraaien kon er nog een groot aantal veranderingen worden aangebracht in tabeltitels, kolomlabels, tabelindelingen, typografie, etcetera. Tijdens deze fase van het onderzoekproces kwam overigens opnieuw duidelijk naar voren dat er tussen de COA's onderling grote verschillen waren qua beschikbare menskracht, expertise en financiële mogel ijkheden.

Met behulp van de verzamelde gegevens en de geproduceerde tabellen is op regionaal niveau in korte tijd een groot aantal rapporten geproduceerd. In schema II wordt daarvan een overzicht gegeven.

Iedere school die heeft meegedaan aan het pilotproject heeft de beschikking gekregen over de belangrijkste onderzoekresultaten met betrekking tot de schoolverlaters van de eigen school. Een dergelijke schoolrapportage bestaat uit grafieken en tabellen, vergezeld van een leeswijzer in de vorm van een standaardtoelichting per tabel. Voor de standaardteksten werd door de COA's Noord-Holland en Rijndelta een concept opgesteld. Dit bevatte hoofdzakelijk een algemene leeswijzer en een tabelgewijze toelichting met daarin de betreffende vraagstelling. De meeste andere COA's hebben van deze standaardteksten gebruik gemaakt. 
De schoolrapportages zijn vertrouwelijk. In de tabellen en grafieken zijn alleen de schoolnumers opgenomen. Over RUBS'89 zijn er in total 256 school rapportages uitgebracht.

De standaardrapportage voor de deelnemende scholen bestaat uit 2 figuren en 12 tabellen. De vorm en inhoud hiervan zijn verschillende malen in het projectteam aan de orde geweest. Naast criteria als overzichtelijkheid, volledigheid en relevantie, werden vorm en inhoud echter tevens bepaald door financiële- en programmatuur-technische beperkingen.

De COA's Flevoland, Gelderland en Noord-Holland slaagden er in om in de rapportages, naast de uitkomsten voor de school, ook al de regionale uitkomsten voor het betreffende schooltype op te nemen. Een dergelijke opzet zou ook in de toekomst moeten worden nagestreefd. Het COA Flevoland heeft in de verslaglegging zeer veel aandacht gegeven aan analyses en aanbevelingen.

Niet alleen in de wijze waarop de rapportage heeft plaatsgevonden, maar ook in de presentatie naar de scholen toe zijn er grote verschillen tussen de COA's waar te nemen. Enkele COA's volstonden met het verzenden van de rapporten, die in een aantal gevallen tijdens het regionaal directeurenoverleg werden besproken. Het COA Flevoland heeft daarentegen op jedere deelnemende school een bijeenkomst belegd met directie en/of dekanen om het rapport te bespreken. Uit deze gesprekken bleek 0.a. dat de scholen veel waarde hechten aan de opsoming die COA-Flevoland had gemaakt van de diverse opmerkingen die de schoolverlaters over de school hadden gemaakt in de ruimte voor 'overige opmerkingen'. Het COA Gelderland heeft een telefonische enquête verricht onder 18 van de 21 in deze provincie deelnemende scholen om na te gaan wat er op de scholen met de rapporten is gedaan. Hieruit bleek dat het RUBSschoolrapport bij 16 van de 18 scholen in het directie-overleg is besproken. Bij 8 scholen is het naar de dekaan of afdelingscoördinator gezonden. Bij 7 scholen is het schoolrapport zelfs naar alle docenten gegaan. Bij 8 scholen is het naar de dekaan of afdelingscoördinator doorgezonden. De meeste scholen hebben de RUBS-resultaten niet rechtstreeks aan hun leerlingen kenbaar gemaakt door bijvoorbeeld schoolkrant of nieuwsbrief. Door de telefonische enquête onder de non-respons werd men echter wel op dit idee gebracht. 
Schema II Soorten rapportages op school-en regionaal niveau per COA, RUBS'89

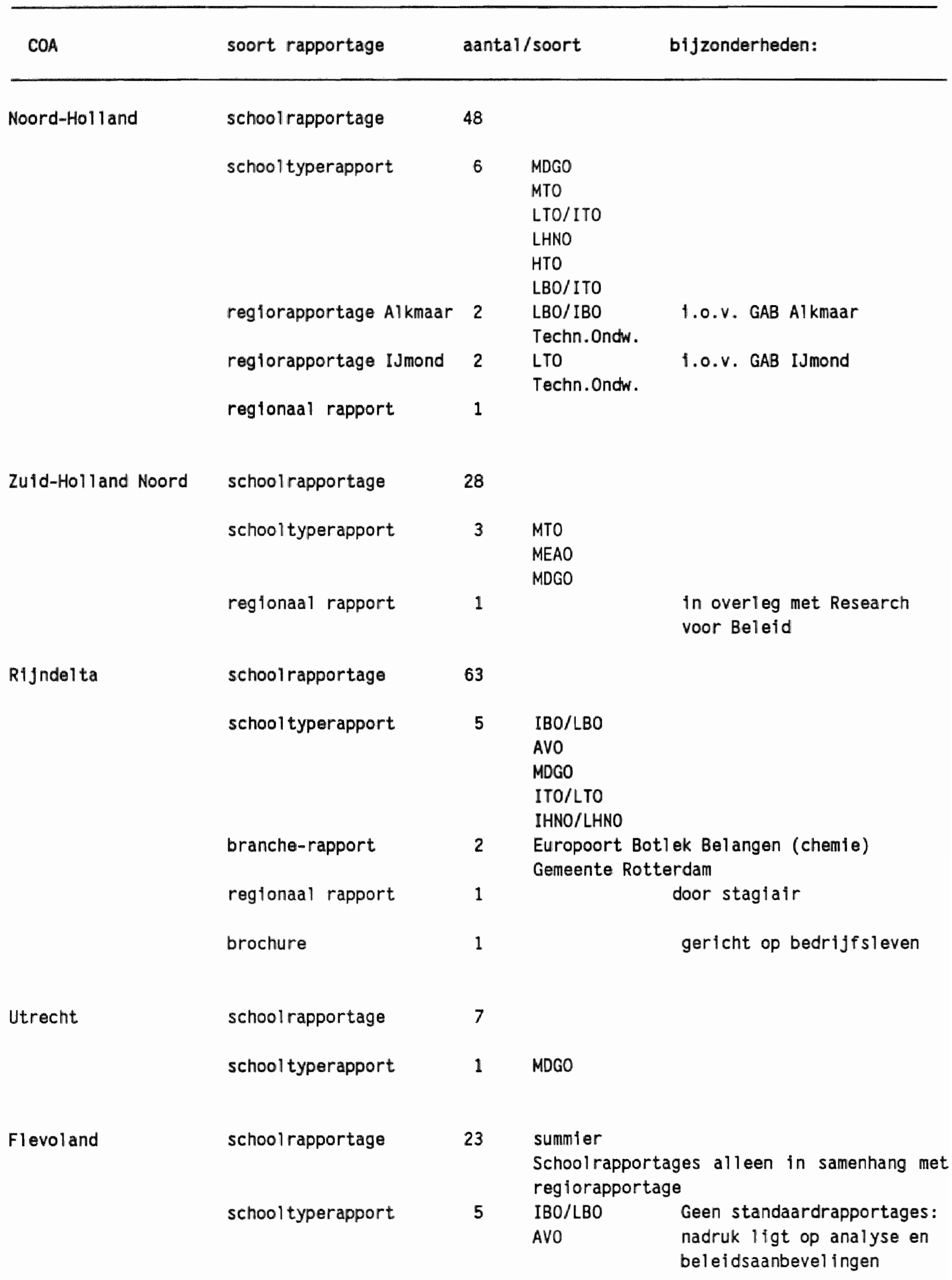




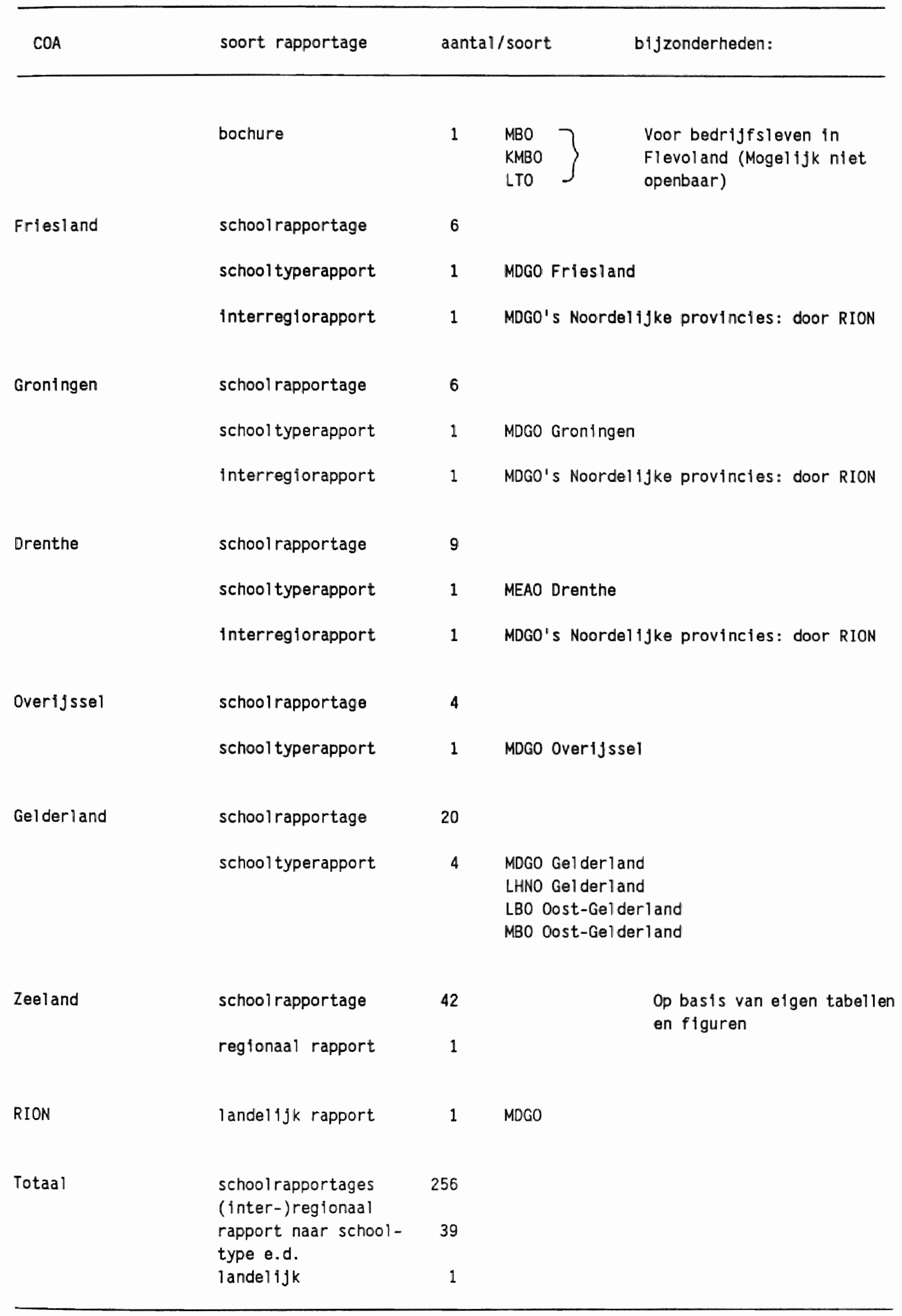


Voor de meeste COA's is het op dit ogenblik echter nog te vroeg om een 'overall' beeld te kunnen geven van het feitelijke gebruik van de RUBSresultaten binnen scholen. Het merendeel van de COA's heeft plannen om zomer of najaar 1990 een studiedag te organiseren naar aanleiding van de RUBSresultaten. Deze studiedagen zullen in de meeste gevallen ook voor diverse andere instanties en doelgroepinstellingen (allochtonen, vrouwen, jongeren, werkgevers, werkzoekenden, etcetera) bestemd zijn.

Ieder COA heeft voor de eigen regio een rapportage per schoolsoort opgesteld. Daarnaast zijn er, afhankelijk van de regionale opdrachtgevers, nog specifieke rapportages op regional niveau verricht. Zo heeft het COA Rijndelta speciale rapportages gemaakt voor de Gemeente Rotterdam en voor 'Europoort Botlek Belangen', een vereniging van chemische bedrijven. COA Noord-Holland heeft voor de arbeidsbureaus IJmond en Alkmaar speciale rapportages gemaakt over respectievelijk het technische onderwijs en het LBO in de desbetreffende GABregio's. Naar de mening van een geraadpleegde staffunctionaris van het Arbeidsbureau Alkmaar voorziet RUBS in een duidelijke behoefte aan vergelijkbare informatie over de uitstroom en besteming van schoolverlaters, daar de schoolverlatersbrief op dit punt een veel te globaal beeld geeft. De huidige RUBS-rapportage wordt daarbij als een 'bevredigende' voortgangsrapportage beschouwd. Veel meer waarde wordt gehecht aan de mede op basis van de RUBS-uitkomsten te maken prognoses van het toekomstige aanbod van schoolverlaters naar hun besteming op de arbeidsmarkt (zie ook hoofdstuk 3 ).

Voor Hoogovens en de gemeente Amsterdam zijn ook enkele specifieke rapportages opgesteld. Nadat een persbericht door enkele kranten was overgenomen is een groot aantal verzoeken om één of meerdere rapporten binnen gekomen, met name van gemeenten, bedrijven, onderzoekbureaus en journalisten. COA Zuid-Holland Noord heeft het voornemen om een populaire versie van de regionale rapportage te laten maken door een extern onderzoekbureau. Hierin zouden dan ook vergelijkingen kunnen worden gemaakt met andere gegevens, zoals bijvoorbeeld de resultaten van de ERBO-enquête, en met de Schoolverlatersbrief.

De vorm van de verschillende rapporten verschilt nogal. Deze verschillen worden voor een deel verklaard door de verschilien in subsidiënten per COA. Zo heeft het COA Flevoland één regionaal rapport samengesteld over de schoolverlaters van het IBO/LBO en het AVO. In dit rapport ligt de nadruk op analyses, conclusies en aanbevelingen ten behoeve van de landelijke- en provinciale beleidsdoelstellingen. De tabellen en grafieken zijn door het 
COA Flevoland opgenomen in een apart tabellenboek.

De COA's Friesland, Groningen en Drenthe hebben voor de rapportages aan de scholen gebruik gemaakt van de eerder genoemde standaardteksten. Alle MDGOschoien uit deze provincies waren in 1989 bij het RUBS betrokken. In opdracht van deze COA's is door het RION een uitgebreide rapportage samengesteld voor het MDGO in de drie noordelijke provincies (Waslander en Van Laarhoven, 1990). Dit rapport is een goed voorbeeld van de wijze waarop een standaardrapportage van de RUBS-enquête er in de toekomst zou kunnen uitzien.

Tevens is door het RION een landelijk rapport samengesteld met betrekking tot het MDGO (Van Laarhoven en Waslander, 1990). Ook dit rapport is min of meer bedoeld om als voorbeeld te dienen voor toekomstige landelijke rapportages van de uitkomsten per schooltype. Vanwege het pilot-karakter van het RUBSproject heeft dit landelijke rapport nast bovengenoemde voorbeeldfunctie echter ook een evaluatieve functie gekregen ten aanzien van de opzet en gevolgde procedures bij het pilotproject.

De dataset zal door het RION worden geordend volgens daarvoor bestaande richtijjnen van het Steinmetz-archief. Deze zal daarna voor het RION en het ROA ter beschikking komen voor verdere analyses. Met de COA's zijn daarover afspraken gemaakt. 


\section{HET TOEKOMSTIGE AANBOD VAN SCHOOLVERLATERS}

\subsection{Doelstelling en opzet}

In het kader van het pilotproject is een poging ondernomen om op basis van de uitkomsten van een schoolverlatersenquête, in combinatie met de gegevens over de instroom van leerlingen, een prognose te maken van de verwachte toekomstige toetreding tot de arbeidsmarkt. Door LCAS en CORO (1990) wordt verslag gedaan van dit deelproject. De resultaten van deze 'vertaalsiag' van de RUBS-uitkomsten zouden, voorzien van commentaar van deskundigen, gebruikt moeten kunnen worden bij de studie- en beroepskeuzevoorlichting. Dit deelproject van RUBS'89 is uitgevoerd door de Stichting Centraal orgaan Regionale Organen (CORO), onder verantwoordelijkheid van de Landelijke Commissie voor de Academische Studievoorlichting (LCAS).

De LCAS heeft zich daarbij als doel gesteld een onderzoekmodel te ontwikkelen op basis waarvan een beeld kan worden verkregen van de kans op passend werk na het behalen van het diploma van een bepalde opleiding.

Daarbij is gebruik gemaakt van de volgende gegevens:

- instroomaantalien;

- uitstroomaantallen van gediplomeerden;

- de belangrijkste bezigheid van gediplomeerden op 1 oktober volgend op hun diplomering.

Het aantal leerlingen dat de opleiding begon (de instroom) en het aantal dat $x$ jaar later het diploma behalde (de uitstroom) werd aangeleverd door de schooladministraties, terwijl de besteming (vervolgopleiding, werk, etc.) van de gediplomeerden op 1 oktober volgend op de diplomering op basis van een schriftelijke enquête onder de schoolverlaters werd achterhaald. Bij een continue monitoring van de besteming van de schoolverlaters in de toekomst, zou gebruik gemaakt kunnen worden van de RUBS-resultaten van een aantal achtereenvolgende cohorten. Hierop voorultlopend was het noodzakelijk in het kader van het pilotproject een drietal opeenvolgende cohorten schoolverlaters gelijktijdig te enquêteren. Op deze wijze kon enige indicatie worden verkregen van de trendmatige ontwikkeling. Schoolverlaters die in 1986, 1987 en 1988 waren uitgestroomd werden gevraagd naar hun situatie op 1 oktober van het jaar waarin zij hun opleiding voltooiden. 
In het pilotproject bestond de onderzoekpopulatie uit 1755 gediplomeerden van drie MDGO-opleidingen en twee MTS-opleidingen. Hiervan hebben, na schriftelijke en telefonische rappellering, uiteindelijk 1351 schoolverlaters gerespondeerd, hetgeen neerkomt op een respons van circa $77 \%$. Dit responspercentage verschilt vrijwel niet van het responspercentage van gediplomeerden uit het MDGO van $74 \%$ in het eerste deelproject (zie Van Laarhoven en Waslander 1990). Daarbij moet echter bedacht worden dat in dit tweede deelproject ook de schoolverlaters uit de jaren 1986 en 1987 zijn geënquêteerd.

Door de LCAS en het CORO is een tweetal vrijwel identieke vragenlijsten ontwikkeld, elk toegesneden op de te bevragen onderwijssoort (zie bijlage LCAS en CORO, 1990). Centraal staan daarbij de vraag naar de globale besteming (militaire dienst, werken en leren, dagopleiding, werkloos, betaald werk) van de schoolverlater op 1 oktober van het jaar waarin men het diploma behaalde en een open vraag naar het beroep of de functie die men op dat moment uitoefende. Op basis van het antwoord op laatstgenoemde vraag is aan de betrokken schooldecaan gevraagd aan te geven of de baan qua aard en niveau aansluit bij de gevolgde opleiding ${ }^{3}$.

In het kader van dit evaluerende rapport is het niet zinvol in te gaan op de uitkomsten van de schoolverlatersenquête van de LCAS en het CORO. Duidelijk is geworden dat er grote verschillen zijn tussen de onderzochte scholen in rendement (de slaagkans), in de toename c.q. afname van het verwachte aantal gediplomeerden in de komende jaren en in de mate warin passend werk wordt gevonden na het behalen van het diploma (de baankans). Wanneer slaagkans en baankans gecombineerd worden zijn de verschillen zelfs schokkend te noemen. Slaagkans en te verwachten aantallen gediplomeerden zijn gegevens die niet door het eerste deelproject worden gegenereerd, het vinden van (passend) werk wel. Voor de exacte resultaten wordt verwezen naar het reeds eerder genoemde separaat uitgebrachte onderzoekverslag. (LCAS en CORO, 1990).

\subsection{Evaluatie}

Bij de evaluatie van dit deelproject dient te worden beseft dat het hier

3. LCAS/CORO (1990) zien dit als een noodoplossing. Voorgesteld wordt in de toekomst het al of niet aansluiten van de baan aan de opleiding op meer objectieve wijze vast te stellen door gebruik te maken van de CBSberoepenclassificatie en de daaraan te koppelen functieniveautypering. 
slechts ging om een pilotproject van bescheiden omvang 4 . De empirische uitkomsten zijn louter als illustratie bedoeld. Bovendien moest noodgedwongen gebruik worden gemaakt van een sterk retrospectieve vraagstelling. Doorgaans neeft dit een negatieve invloed op de kwaliteit van de gegeven antwoorden. Gezien de feitelijkheid van de vragen (aanvangsjaar van de opleiding, werk op 1 oktober na de diplomering, omvang van deze betrekking) lijkt het niet waarschijnlijk dat dit hier ook het geval is. Bij de bespreking van dit deelproject in de begeleidingscommissie is een aantal andere kritiekpunten genoemd ten aanzien van de aanpak van de LCAS en het CORO, zoals de te smalle basis (drie waarnemingsjaren) warop de extrapolaties hebben plaatsgevonden en de minder gelukkige verwerking van de non-respons in de tabellen. De smalle basis is geen pincipiële kwestie, doch vloeit voort uit de beperkte mogelijkheden van het pilotproject. In de toekomst zal bij een jaarijjks onderzoek deze basis vanzelf breder worden. Wat betreft de non-respons 1 igt het anders. De LCAS en het CORO hebben de non-respons niet toegerekend naar de verschillende categorieën, maar ondergebracht in de categorie onbekend. Vanuit het oogpunt van voorlichting en in verband met de selectiviteit van de non-respons werd dit juister geacht. Bovendien worden fluctuaties in de non-respons op deze wijze zichtbaar. Het nadeel van deze aanpak is dat verschillen in de nonrespons tussen scholen van invloed zijn op de vaststelling van het percentage schoolverlaters dat gaat werken, doorleren of werkloos is. In de toekomst lijkt ons een andere aanpak van de non-respons derhalve gewenst. Zoa1s ook reeds in hoofdstuk 2 werd opgemerkt, mag bij een dergelijke aanpak een adequate non-responsanalyse niet ontbreken. Omdat het hier niet gaat om principlële beperkingen van het voorgestelde onderzoekmodel, maar slechts om kwesties die in de toekomst zonder veel problemen kunnen worden opgelost, willen we ons hier beperken tot het bespreken van enkele meer fundamentele punten van het onderzoekmodel en de presentatie van de resultaten.

In principe kan worden gesteld dat het ontwikkelde onderzoekmodel uiterst zinvolle prognose-uitkomsten oplevert, voor zover een beeld wordt geschetst van de te verwachten uitstroom uit het onderwijs, verbijzonderd naar vakrichting en regio. Zoals in hoofdstuk $4 \mathrm{zal}$ worden betoogd, kan deze informatie met name van belang zijn voor het bedrijfsleven, dat op deze wijze een indruk kan krijgen van het toekomstige aanbod waaruit nieuw personeel moet worden gerecruteerd. De uitkomsten zijn ons inziens echter njet toereikend

4. Voor dit deelproject was slechts $f 20.000,--$ beschikbaar. De resterende onderzoekkosten moesten uit de lopende begroting van de LCAS worden gefinancierd. 
voor het beoogde gebruiksdoel, de studie- en beroepskeuzevoorlichting, ondat het hier alleen een projectie betreft van het onderwijsaanbod op de arbeidsmarkt. Om adequate uitspraken te kunnen doen over de kans op werk met een bepaalde opleiding is het tevens noodzakelijk om, net zoals ten behoeve van het informatiesysteem voor beroeps-en opleidingskeuze I-See! is gebeurd, naast deze aanbodprognose ook een prognose te maken van de ontwikkelingen aan de vraagzijde van de arbeidsmarkt. Daarbij gaat het om het verwachte aantal 'job-openings' naar vakrichting in de diverse regio's. Het totale aantal voorspelde 'job-openings' is daarbij de som van de verwachte werkgelegenheidsontwikkeling en de verwachte vervangingsuraag (zie ook De Grip, Heijke en Dekker, 1990).

Een belangrijke vraag naar aanleiding van het LCAS/CORO-onderzoek is of het wenselijk is aanbodprognoses op te stellen voor individuele scholen c.a. vakrichtingen. Hoewel dergelijke prognoses met name voor het schoolmanagement nuttige informatie kunnen opleveren, is een dergelijke voor alle scholen systematische opzet in de toekomst wellicht niet haalbaar, vanwege de enorme omvang van de werkzaamheden die dit met zich mee zou brengen. Het ligt meer voor de hand om prognoses op regionaal niveau op te stellen voor de verschillende onderwijstypen $c . q$. vakrichtingen. Het is dan niet meer nodig de gegevens over de instroom in het onderwijs door middel van het RUBS-project te verzamelen, omdat gebruik zou kunnen worden gemaakt van de integrale leerlingentellingen van het Ministerie van Onderwijs en Wetenschappen. In principe zou ook kunnen worden voortgebouwd op de regionale 'PRUSO'-prognoses die het Instituut voor Ruimtelijke Organisatie van TNO in opdracht van het Ministerie van Onderwijs en Wetenschappen opstelt 5 (zie ook hoofdstuk 4). Tenslotte zijn er twijfels over de inzichtelijkheid van de grafische presentatie van de resultaten als voorlopig eindprodukt van dit tweede deelproject. Helaas is de LCAS niet in staat geweest de beoogde vertaalsiag en de evaluatie daarvan binnen de termijn van het project uit haar eigen begroting te financieren. Het was haar bedoeling daarin de grafische voorstelling opnieuw vorm te geven, aan te vullen met een verbale interpretatie en 'commentaar' van deskundigen over de te verwachten ontwikkeling van de vraagzijde.

Wel zijn de werkwijze en de uitkomsten van dit deelproject onlangs ter beoor-

5. Een mogelijk probleempunt is daarbij dat deze prognoses betrekking hebben op zogenaamde 'nodale' gebieden. 
deling voorgelegd op de werkconferentie van de LCAS over arbeidsmarktvoorlichting 'baanzekerheid begeleiden'. Op deze werkconferentie werd vrijwel unaniem vastgesteld dat het RUBS-project zeer de moeite waard is voor de studie- en beroepskeuzevoorlichting. Wel werd er daarbij op gewezen dat een 'heldere samenvatting' noodzakelijk is waarin de uitkomsten ook worden geinterpreteerd. De 'overdaad aan tabelien en grafieken' schiet op dit punt tekort. Bovendien wordt opgemerkt dat het onbecommentarieerd uitbrengen van de RUBS-resultaten het risico met zich meebrengt dat deze resultaten een onbedoeld eigen leven gaan leiden. Daarnaast werd er op de werkconferentie op gewezen dat de voortijdige schoolverlaters eveneens in het RUBS-onderzoek moeten worden betrokken, zoals overigens ook het geval is geweest in het eerste deelproject.

Op basis van het bovenstaande kan worden geconcludeerd dat de LCAS en het CORO een in principe zinvolle methodiek hebben ontwikkeld voor het geven van een indicatie van het toekomstige aanbod van schoolverlaters naar regio en vakrichting, waarbij bovendien kan worden verbijzonderd naar de verschillende beroepscategorieën en/of bedrijfssectoren. Het is duidelijk dat deze methodiek slechts één zijde van de arbeidsmarkt in kaart brengt. Dergelijke aanbodprognoses kunnen voor het bedrijfsleven nuttige informatie opleveren over het toekomstige aanbod op de arbeidsmarkt in de verschillende opleidingsrichtingen, waaruit men schoolverlaters zal moeten recruteren. Voor de studie- en beroepskeuzevoorlichting kan echter niet worden volstaan met prognoses van alleen de aanbodzijde van de arbeidsmarkt. Om tot een prognose te komen van de kansen op werk van schoolverlaters, is het noodzakelijk de hier gemakte aanbodprognoses te confronteren met prognoses van de vraagzijde van de arbeidsmarkt. Het is het meest efficiënt derge 11jke prognoses niet op het niveau van individuele scholen, maar op regionaal niveau op te stellen. Daarbij kan gebruik worden gemaakt van reeds bestaande gegevensbestanden. Wat de presentatie betreft van de voorspelde kansen op werk voor schoolverlaters van de verschillende opleidingen, is het vooralsnog onduidelijk in hoeverre een grafische presentatie inzichtelijker is dan bijvoorbeeld de kwalitatieve typeringen van de arbeidsmarktperspectieven ('goed, redelijk, matig, slecht en erg slecht') die momenteel worden gehanteerd in I-See!. Voor het gebruik van de RUBS-gegevens ten behoeve van de studieen beroepskeuzevoorlichting, zou een inkadering van de RUBS-uitkomsten in ISee! een verantwoorde 'heldere samenvatting van de arbeidsmarktperspectieven' van schoolverlaters en de interpretatie hiervan kunnen bewerkstelligen. 


\section{DE TOEKOMST VAN RUBS ALS INFORMATIE-INSTRUMENT}

\subsection{Inleiding}

In dit hoofdstuk zal een voorstel worden ontwikkeld voor de toekomstige opzet van de RUBS-schoolverlatersenquête en de organisatie-en financieringsstructuur van waaruit een dergelijke grootschalige schoolverlatersenquête zou kunnen plaatsvinden. Dit voorstel worat ontwikkeld mede in het licht van de bij het RUBS-pilotproject opgedane ervaringen. Eerst zal in paragraaf 4.2 . een beeld worden geschetst van een aantal belangrijke gebruiksdoelen en gebruikersgroepen van de RUBS-enquête. Daarbij zal telkens worden ingegaan op de gebruikswaarde die RUBS voor de desbetreffende doelgroep kan hebben en op de concrete 'produkten' waarmee in de informatiebehoefte van de desbetreffende doelgroep kan worden voorzien. Vervolgens komen in paragraaf 4.3. de diverse technische aspecten van een grootschalig schoolverlatersonderzoek aan de orde. Eerst worden in paragraaf 4.3.1. enkele technische aspecten, zoals het moment van enquêteren, de opzet van de vragenlijst e.d. summier besproken. Hierbij wordt voortgebouwd op de evaluatie van het RUBS-pilotproject in de hoofdstukken 2 en 3 en het door het RION opgestelde onderzoekontwerp voor het RUBS-project. Daarna wordt een drietal alternatieven naar voren gebracht met betrekking tot de toekomstige algehele opzet van het schoolverlatersonderzoek. Er zal door ons een voorkeur worden uitgesproken voor twee van deze alternatieven. In paragraaf 4.4. zal in aansluiting op de in paragraaf 4.3. bepleite onderzoekopzet een globale schets worden gegeven van een mogelijke organisatiestructuur, het bijbehorende kostenplaatje en de financieringsstructuur. Ten slotte wordt in paragraaf 4.5. een voorstel gedaan voor de wijze warop de verdere ontwikkeling van het RUBS-project zou kunnen plaatsvinden.

\subsection{Gebruikersgroepen en informatieprodukten}

\subsubsection{Gebruiksdoelen en gebruikersgroepen}

Zoals in het eerste hoofdstuk reeds werd opgemerkt, is de primaire doelstelling van het RUBS-project het ontwikkelen van een meetinstrument op basis warvan een continue monitoring kan plaatsvinden van de bestemming van schoolverlaters. Daarbij staat de eerste besteming op de arbeidsmarkt centraal. Hierdoor kan een actueel beeld worden verkregen van de aanslui- 
tingsproblematiek tussen onderwijs en arbeidsmarkt voor de schoolverlaters, verbijzonderd naar opleidingstype, c.q. vakrichting. Diverse aspecten van de aansluitingsproblematiek kunnen daarbij worden belicht:

- relatieve omvang werkloosheid;

- relatie opleiding-beroep;

- bedrijfssectoren waar men werk vindt;

- wijze waarop men aan een baan is gekomen;

- beloning;

- eventuele aanvullende scholing;

- 'kwalitatieve aansluitingsprobiemen': beoordeling curriculum e.d. in het licht van de huidige werkzaamheden of vervolgopleiding.

Naast deze direct uit de RUBS-enquête afleidbare gegevens met betrekking tot de aansluiting tussen opleiding en werk kan de RUBS-enquête ook een uiterst belangrijk aanvullend databestand opleveren waarmee prognosemodellen voor arbeidsmarktontwikkelingen kunnen worden geschat en indicatoren voor de uitwijkmogelijkheden op de arbeidsmarkt, e.d. kunnen worden berekend. De RUBS-gegevens bieden op dit punt mogelijkheden voor zowel een verfijning naar opleidingstype/vakrichting, als een regionalisering van een informatiesysteem onderwijs-arbeidsmarkt, zoals dat bijvoorbeeld door het ROA in het kader van het Project Onderwijs en Arbeidsmarkt (POA) en het ISeel project wordt ontwikkeld.

Langs bovengenoemde directe en indirecte weg kunnen de RUBS-gegevens een belangrijke informatiebron vormen voor de volgende gebruiksdoelen:

- het schoolmanagement;

- de studie- en beroepskeuzevoorlichting;

- het onderwijsbeleid;

- het arbeidsvoorzieningsbeleid;

- het personeelsbeleid c.q. wervingsbeleid.

Voor het schoolmanagement is de betekenis van de RUBS-enquête vooral gelegen in het verschaffen van een integraal beeld van de besteming van de leerlingen die de eigen school hebben verlaten. Deze besteming betreft zowel de arbeidsmarkt als het vervolgonderwijs. De arbeidsmarktsituatie wordt globaal getypeerd op basis van het percentage werkloze schoolverlaters van de verschillende vakrichtingen. Daarnaast worden gegevens verschaft die een nauwkeurig beeld geven van de verschillende beroepen en bedrijfssectoren warin de werkende schoolverlaters terecht komen, de behoefte aan aanvullen- 
de scholing en de beoordeling van diverse aspecten van de kwalitatieve aansluiting tussen de gevolgde opleiding en het huidige werk of de huidige vervolgopleiding. Op deze wijze levert de RUBS-enquête een belangrijke basis voor een evaluatiekader voor het beoordelen van het huidige curriculum, de voorlichting van de leerlingen met betrekking tot de te kiezen vakrichting of afstudeerrichting, de begeleiding van de eindexamenkandidaten bij het zoeken naar werk, mogelijke stage-adressen, het ontwikkelen van voorlichtingsmateriaal voor de werving van nieuwe leerlingen, etcetera. In feite kan RUBS daarbij fungeren als een instrument ter bewaking van de 'externe' kwaliteit van het onderwijs, c.q. voor een zogenaamde 'produktevaluatie' ten aanzien van de schoolverlaters. De RUBS-uitkomsten zouden daarbij ook gebruikt kunnen worden voor het samenstellen van een jaarverslag waarin de school rapporteert over de 'bedrijfsresultaten' van de eigen onderwijsinsteling. Een dergelijk jaarverslag wordt bepleit in het 'Advies Rendement Onderwijs' van de Sociaal Economische Raad (SER, 1990).

Voor het schoolmanagement biedt de RUBS-enquête ook mogelijkheden on de arbeidsmarktrelevantie van hun opleidingsrichtingen te onderbouwen met 'arbeidsmarktplaatjes'. Met name de gegevens over de beroepen en/of bedrijfssectoren waarin de schoolverlaters van een bepaalde vakrichting terecht komen kurnen op dit punt een aanknopingspunt bieden. Daarnaast bledt de RUBSenquête ook concrete aangrijpingspunten om met het latere werkveld van de schoolverlaters van gedachten te kunnen wisseien, zoals momenteel bijvoorbeeld gebeurt in het kader van het Branchegewijs Overleg Onderwijs Bedrijfsleven (BOOB's). Bovendien stelt de RUBS-enquête de scholen in staat om jaarlijks een uitstroomprofiel van de schoolverlaters te geven, zoals in het kader van de SVM-wetgeving van de instellingen voor het middelbaar beroepsonderwijs wordt geëist. Ook vormt de RUBS-enquête een logische aanvulling op een zogenaamd 'leerlingenvolgsysteem' voor onderwijsinstellingen, zoals dat wordt bepleit in het bovengenoemde Advies Rendement Onderwijs van de SER (1990).

Zoals enkele schooldirecteuren bij de evaluatie van het pilotproject opmerkten, kan de RUBS-enquête duidelijk als een 'eye-opener' werken: 'er ontwikkelt zich een kwaliteitsbewustzijn'. Daarbij wordt dan gedacht aan een zorgvuldiger toelatingsbeleid, soms leidend tot een 'intake-gesprek' en meer persoonlijke begeleiding en aandacht voor (dreigende) 'drop-outs'.

Uit reacties van de scholen blijkt dat voor het schoolmanagement doorgaans alleen de belangrijkste conclusies en de meest saillante uitkomsten van belang 
zijn. Door afdelingen en individuele docenten wordt echter ook veel waarde gehecht aan de diverse details van de tabellen en grafieken.

In een publicatie van een zevental samenwerkende (K)MBO scholen ZaanstreekWaterland (1989) wordt ook gewezen op de bijdrage die RUBS kan leveren aan een 'Beleid gericht op Uitstroom Profiel Ontwikkeling (BUPO)'. Een dergelijk beleid zou volgens de samenwerkende scholen gericht moeten zijn op het bewaken van de kwaliteitszorg van het gegeven onderwijs in het algemeen en het 'systematisch beinvloeden van het uitstroomprofiel van een school en het bewust nastreven van verbetering hiervan' in het bijzonder. Daarbij wordt onder meer gedacht aan het sturen van leerlingstromen in de richting van perspectiefvolle leerroutes.

Een belangrijke meerwaarde van het RUBS-project ten opzichte van een incidenteel door de school te houden schoolverlatersenquête, is de mogelijkheid om de bovengenoemde aspecten van de aansluitingsproblematiek van de schoolverlaters van de eigen school te vergelijken met het regionale of landelijke beeld voor de desbetreffende vakrichtingen. Bovendien zou het RUBS-project kunnen zorg dragen voor continuiteit in het volgen van de schoolverlaters, zodat met recht gesproken kan worden van een monitoring van de aansluitingsproblematiek. Een dergelijke continuyteit is van groot belang omdat van (kleine) verschuivingen in de tijd een belangrijke signalerende werking kan uitgaan naar het schoolmanagement. Hierdoor wordt het gevaar vermeden dat het onderzoek pas plaatsvindt als bepaalde problemen zich reeds openbaren, zoals bij incidenteel schoolverlatersonderzoek nogal eens het geval is.

Een tweede belangrijk gebruiksdoel van de RUBS-enquête is de studie- en beroepskeuzevoorlichting. In de eerste plaats kan het daarbij gaan om het directe gebruik dat individuele scholen van de RUBS-resultaten met betrekking tot hun eigen school kunnen maken bij de voorlichting aan potentiële nieuwe leerlingen. Zo wijzen enkele scholen er op dat de RUBS-resultaten de advisering aan individuele leerlingen kunnen vergemakkelijken. In de tweede plaats vormen de landelijke en vooral de regionale enquête-uitkomsten naar opleiding of vakrichting een belangrijke informatiebron voor schooldecanen, arbeidsbureaus, beroepskeuzevoorlichters e.d. Enerzijds gaat het daarbij om de directe RUBS-resultaten, zoals de monitoring van de relatie opleidingberoep en de eventueel daarbij spelende aansluitingsproblemen, anderzijds kunnen de na bewerking verkregen RUBS-gegevens een cruciale rol spelen bij 
een verdere verfijning naar zowel vakrichting als regio van het informatiesysteem voor beroeps- en opleidingskeuze $I$-Seel zo maken de RUBSgegevens het mogelijk een veel nauwkeuriger beeld te geven van de uitwijkmoge lijkheden op de arbeidsmarkt voor schoolverlaters met een bepaalde opleidingsachtergrond en van de relatie vakrichting - beroep, dan op basis van het thans beschikbare datamateriaal mogelijk is. Daarnaast vormen de RUBS-gegevens een belangrijke informatiebron voor het schatten van modellen voor het maken van prognoses van de arbeidsmarktperspectieven van opleidingen en beroepen. Daarbij kan gedacht worden aan het bieden van de mogelijkheid tot het regionaliseren van de aanbodprognoses naar opleiding en beroep, voortbouwend op de in het LCAS/CORO-subproject geinitieerde methodiek, en het regionaliseren van de prognoses van de te verwachten 'job-openings' voor schoolverlaters.

De waarde van de RUBS-enquête voor het I-Seel-systeem overstijgt overigens de waarde die de gegevens kunnen hebben voor de arbeidsmarktmodule. De RUBSuitkomsten maken het immers ook mogelijk de beroepen- en opleidingenmodules van I-See! in belangrijke mate te verrijken. Zo vormt RUBS een actuele informatiebron met betrekking tot de 'mogelijke beroepen' voor de schoolverlaters van een bepalde vakrichting en wordt een indicatie verkregen van het beginsalaris naar beroep en/of opleiding. Waarschijniljk nog meer belovend zijn de mogelijkheden die RUBS biedt voor het verrijken van het I-See!-systeem met gegevens over de kwalitatieve aansluitingsproblematiek en de door schoolverlaters eventueel gevolgde aanvullende training of scholing.

Vanzelfsprekend kunnen de RUBS-gegevens een belangrijke informatiebron vormen voor meer voorlichtingsprodukten dan hierboven zijn genoemd. Daarbij kan met name worden gedacht aan de schoolverlatersbrief van het Ministerie van Sociale Zaken en Werkgelegenheid, warvoor de uitkomsten van de RUBS-enquête een schat aan informatie bevatten. Daarnaast zullen op regionaal niveau de Regionale Dienstverlenende Centra i.o. (RDC'S) mede op basis van de RUBSuitkomsten diverse voorlichtingsprojecten kunnen ontwikkelen.

Tenslotte zouden de RUBS resultaten ook gebruikt kunnen worden voor de toetsing van de arbeidsmarktprognoses en voor de evaluatie van de effecten en de timing van overheidscampagnes op het terrein van de studie- en beroepskeuzevoorlichting.

De uitkomsten van de RUBS-enquête kunnen ook een belangrijke signalerende 
functie hebben voor het onderwijsbeleid. Het betreft hier met name de monitoring van de aansiuiting tussen onderwijs en arbeidsmarkt. Hierbij zou het ter beschikking stellen van de resultaten van individuele scholen aan het Ministerie van Onderwijs en Wetenschappen of de provinciale en gemeentelijke overheden een probleem kunnen vormen. Dit zou imers de bereidheid van scholen om in het RUBS-project te participeren negatief kunnen beinvloeden. Het is overigens de vraag in hoeverre dit nog een probleem vormt wanneer belangrijke aspecten van de onderwijsplanning worden gedelegeerd aan het schoolmanagement. Bovendien kan men zich afvragen in hoeverre juist het vergroten van de beleidsurijheid van individuele scholen, het gewenst maakt dat scholen ook informatie verschaffen over de kwaliteit van het onderwijs in ruime zin.

Behalve de gegevens van individuele scholen zal ook het landelijke of totale beeld van een bepald opleidingstype voor het onderwijsbeleid van belang kunnen zijn. Daarbij gaat het met name om gegevens over de relatieve werkloosheid, de ontwikkelingen van het beroepsdomein van opleidingen, de beoordeling van de gevolgde opleiding door de schoolverlaters in het licht van hun huidige werk of de gevolgde vervolgopleiding en de door schoolverlaters gevolgde cursussen en trainingen. Voor de planning van de doorstroom binnen het onderwijs is de waarde van de RUBS-ultkomsten daarentegen beperkt, omdat de administratieve gegevens over de herkomst van de leerlingeninstroom van de verschillende opleidingen op dit punt waarschijniljk een grotere betrouwbaarheid hebben. Het in het kader van het Project Onderwijs Arbeidsmarkt (POA) van het Ministerie van Onderwijs en Wetenschappen door het ROA opgezette informatiesysteem onderwijs-arbeidsmarkt zou met behulp van de RUBS gegevens verder kunnen worden ontwikkeld (zie ook ROA, 1989). Daarbij kan bijvoorbeeld gedacht worden aan, het op een veel lager aggregatieniveau dan nu het geval is, in kaart brengen van de uitwijkmogelijkheden van schoolverlaters op de arbeidsmarkt of andere arbeidsmarktindicatoren op basis van de bovengenoemde gegevens. Zoals gezegd zal het hierbij niet zozeer gaan om arbeidsmarktprognoses, mar in principe om de monitoring van de aansluiting tussen onderwijs en arbeidsmarkt.

Een vierde doelgroep van de gegevens uit de RUBS-enquête vormt het arbeidsvoorzieningsbeleid. Vanuit de Arbeidsbureaus wordt een viertal mogelijke gebruiksdoelen genoemd warin de RUBS-uitkomsten zouden kunnen voorzien:

- managementinformatie Arbeidsbureau;

- activiteiten regionale arbeidsmarktonderzoekers; 
- scholingsprograma's;

- regionale voorlichtingsprogramma's.

Er wordt daarbij gewezen op de behoefte aan onderling vergelijkbare informatie over de bestemming van de schoolverlaters: 'De schoolverlatersbrief geeft hiervan momenteel een veel te globaal beeld'.

Ook ten aanzien van het arbeidsvoorzieningsbeleid kan een onderscheid worden gemakt tussen de directe bruikbaarheid van de RUBS-gegevens en de indirecte gebruiksmogelijkheid van de gegevens voor het maken van arbeidsmarktprognoses. Voor het arbeidsvoorzieningsbeleid kan RUBS in de eerste plaats een nuttig instrument vormen voor het monitoren van het marktaandeel van de arbeidsbureaus bij de bemiddeling en de platsing van schoolverlaters op de arbeidsmarkt. Dit zou kunnen op basis van de vragen naar de wijze waarop werkenden aan werk zijn gekomen en naar de wijze waarop werklozen en werkenden de afgelopen vier weken naar (ander) werk hebben gezocht, en op basis van de vraag of men al dan niet staat ingeschreven bij het arbeidsbureau. Een interessante mogelijkheid op dit punt is ook het verbijzonderen van de antwoorden op de vraag hoe men aan werk gekomen is naar de periode die het de schoolverlater heeft gekost voor hij of zij een eerste baan heeft gevonden. Daarnaast is de informatie over de beroepen warin schoolverlaters met een bepalde opleidingsachtergrond (eventueel via andere wegen dan het arbeidsbureau) zijn terecht gekomen van belang voor de arbeidsbemiddeling en, eventueel in combinatie met de gegevens over de door werkenden of werklozen gevolgde cursussen, e.d. voor het scholingsbeleid van arbeidsbureaus, Centra voor Vakopleidingen van Volwassenen, Vrouw en Werkwinkels e.d..

Met name ten behoeve van het scholingsbeleid zal gebruik gemaakt kunnen worden van prognoses van de arbeidsmarktperspectieven van de verschillende beroepen en opleidingen waarvoor RUBS, zoals reeds eerder is opgemerkt, een belangrijke aanvullende bron van statistische gegevens kan vormen. In het kader van het bovengenoemde ROA-informatiesysteem onderwijs-arbeidsmarkt wordt momentee 1 gewerkt aan een informatie-instrument voor het scholingsbeleid. Met name de verwachte 'job-openings" (werkgelegenheidsontwikkeling en vervangingsvraag) van de diverse beroepen binnen de verschillende bedrijfssectoren op een termijn van één tot twee jaar staan hierbij centraal. Deze prognoses van de ontwikkelingen aan de vraagzijde van de arbeidsmarkt zouden kunnen worden gecombineerd met prognoses van het te verwachten aanbod van schoolverlaters, mede op basis van de door de LCAS en het CORO geinitieerde methodiek. Ook in het kader van het zogenaamde 'experiment scholingsplanning' kunnen de RUBS- 
gegevens, en met name de op basis daarvan opgestelde prognoses van het te verwachten aanbod van schoolverlaters, een belangrijke informatiebron vormen. Beleidsmedewerker Schuurer van het Arbeidsbureau Alkmaar wijst ook op het belang van dergelijke vraag- en aanbodprognoses: er zou in kaart gebracht kunnen worden hoe de behoefte aan vakgeschoold personeel in de verschillende sectoren van het beroepsleven zich op de wat langere termijn zal ontwikkelen. Vervolgens zou er een koppeling gelegd kunnen worden met de te verwachten uitstroom bij de op die sectoren gerichte opleidingen. Bijjkt dan dat de te verwachten uitstroom belangrijk achter zal blijven bij de behoeftenprognoses, dan zouden door het GAB bijtijds in samenwerking met werkgevers (bijvoorbeeld branche-organisaties) scholingsplannen kunnen worden gemaakt (COA NoordHolland, Nieuwsbrief 1989).

Het vijfde gebruiksdoel van de RUBS-gegevens vormt het personeelsbeleid en in het bijzonder het wervingsbeleid van het bedrijfsleven en de overheid op de arbeidsmarkt. De monitoring van de regionale werkloosheid naar vakrichting vormt een belangrijke informatiebron voor het wervingsbeleid. Dok de informatie over wat de concurrerende beroepen en bedrijfstakken zijn voor de schoolverlaters met een bepalde opleidingsachtergrond (de concurrerende vraag), is uitermate nuttig voor het bepalen van de wervingsstrategie. Hetzelfde geldt voor de informatie over de regio, c.q. de plaats waar schoolverlaters (bereid zijn te) gaan werken. Daarnaast kan op een deelmarkt, waar sprake is van wervingsproblemen, de informatie over de mate waarin werkenden op zoek zijn naar ander werk en de wijze waarop zij naar werk zoeken, nuttig zijn. Tenslotte kan de informatie over de door schoolverlaters ervaren kwalitatieve discrepanties in de aansluiting tussen de gevolgde opleiding en de huidige werksituatie een signaalfunctie hebben voor het personeelsbeleid dat in de desbetreffende branches wordt gevoerd.

\subsubsection{Informatieprodukten}

In het kader van het pilotproject is een aantal nieuwe informatieprodukten ontwikkeld waarmee de verschillende gebruikersgroepen in hun informatiebehoefte kunnen worden voorzien. De RUBS-uitkomsten kunnen, zoals in paragraaf 4.2.1. werd aangegeven, daarnaast ook een belangrijke bijdrage leveren aan reeds bestaande informatieprodukten, of een aanzet geven tot het ontwikkelen van nieuwe produkten. 
Het schoolmanagement en de andere gebruikersgroepen binnen de individuele scholen (afdelingen of individuele docenten) kunnen het beste van informatie worden voorzien door middel van een standaardrapportage over de RUBSuitkomsten van de eigen school. Daarnaast moet zodanige informatie aan de scholen worden verstrekt dat zij een vergelijking kunnen maken met het regionale en landelijke beeld van het desbetreffende schooltype. Vanwege het grote aantal rapportages dat moet worden opgesteld, zal het beste kunnen worden gewerkt met een standaardrapportage die zich beperkt tot een aantal gedetailleerde tabellen en enkele globale grafieken. De tabellen en grafieken kunnen daarbij vergezeld gaan van een korte tekst, waarin de opzet van de desbetreffende tabel of grafiek wordt toegelicht en eventueel wordt aangegeven welke informatie er in principe uit zou kunnen worden gehaald. Er zal derhalve niet worden ingegaan op de uitkomsten zelf.

De regionale en landelijke rapporten met betrekking tot het eigen opleidingstype zullen het schoolmanagement een duidelijk beeld moeten geven van de belangrijkste conclusies en de meest saillante uitkomsten van de RUBS-enquête voor het desbetreffende schooltype. Wanneer scholen informatie willen hebben die niet in bovengenoemde standaardrapportages wordt verstrekt, zoals bijvoorbeeld meer-dimensionale kruistabellen op basis van combinaties tussen de antwoorden op verschillende vragen, zou hierin kunnen worden voorzien op bas is van aanvullende 'maatwerkrapportages'. Deze maatwerkrapportages zullen op verzoek van de school zelf worden samengesteld. Een mogelijk alternatief voor derge 1 ijke maatwerkrapportages is het ontwikkelen van een geautomatiseerd informatiesysteem, op basis waarvan het schoolmanagement in principe alle informatie die aanwezig is over de schoolverlaters van de eigen school kan vergelijken met het regionale of landelijke beeld. Een nog verder gaande mogelijkheid is het integreren van de RUBS-informatie in een algeheel management informatiesysteem ten behoeve van de schoolleiding.

In paragraaf 4.2.1. werd bij de studie- en beroepskeuzevoorlichting als gebruiksdoel van de RUBS uitkomsten een onderscheid gemaakt tussen het gebruik dat individuele scholen van de resultaten voor de eigen school kunnen maken en de bijdrage die de uitkomsten kunnen leveren aan de verbetering van het bestaande studie- en beroepskeuzevoorlichtingsmateriaal en informatiesystemen.

Bij de voorlichting aan potentiële leerlingen van een bepalde school kan gebruik worden gemaakt van de bovengenoemde schoolrapportage. Daarnaast kunnen de verschillende regionale en landelijke rapportages een rol spelen bij 
de voorlichting over vervolgstudies en mogelijke beroepen. Waarschijnijijk is het voor dit gebruiksdoel echter praktischer om gebruik te maken van bestaande informatiesystemen warin de RUBS-uitkomsten zijn verwerkt. Het informatiesysteem voor beroeps- en opleidingskeuze I-See! zou op dit punt een belangrijke rol kunnen spelen. Daarnaast werd reeds gewezen op de schoolverlatersbrief van het Ministerie van Sociale Zaken en Werkgelegenheid. Bovendien kunnen de ROC's en/of de Rijksoverheid mede op basis van de RUBS-uitkomsten diverse (ad hoc) voorlichtingsprojecten c.q. campagnes ontwikkelen.

Ten aanzien van het onderwijsbeleid kan er van de verschillende regionale en landelijke standaardrapportages een duidelijke signalerende werking uitgaan. Zoals opgemerkt kunnen er misschien problemen rijzen als de overheid zonder meer inzage krijgt in de standaard schoolrapportages van de individuele scholen. Hierover zullen derhalve nadere afspraken moeten worden gemaakt tussen het Ministerie en de scholen. Bovendien kunnen de scholen, mede op basis van de RUBS-resultaten van de eigen school, de overheid op eigen initiatief van een 'arbeidsmarktplaatje' voorzien wanneer een verzoek wordt gedaan voor het starten van een nieuwe studie- of vakrichting. Naast de voor de hand liggende schriftelijke regionale en landelijke standaardrapportages, bieden de RUBS-gegevens, zoals reeds eerder is opgemerkt, ook de mogelijkheid voor een verregaande verfijning van het in het kader van het POA-project ontwikkelde ROA-informatiesysteem onderwijs-arbeidsmarkt. Daarbij zou ook kunnen worden gedacht aan het ontwikkelen van een geautomatiseerd informatieprodukt ten behoeve van het onderwijsbeleid, op basis van de RUBSuitkomsten, aangevuld met andere informatiebronnen.

De RUBS-vragenlijst bevat een aantal vragen die specifiek inspelen op de rol van de arbeidsvoorziening bij het zoeken naar en het vinden van een eerste baan. Er zou daarom kunnen worden overwogen om, naast de regionale en landelijke standaardrapportages voor de verschillende schooltypen, een specifieke 'maatwerkrapportage' te ontwikkelen voor de arbeidsvoorziening. In deze rapportage zou kunnen worden ingegaan op de in paragraaf 4.2.1. genoemde aandachtspunten die van belang zijn voor de arbeidsbemiddeling, het scholingsbeleid e.d.

Daarnaast zou, zoals reeds is opgemerkt, ten behoeve van het scholingsbeleid gebruik kunnen worden gemaakt van de korte-termijn voorspellingen van de werkgelegenheidsperspectieven van beroepen binnen de verschillende bedrijfssectoren, zoals die in het kader van het ROA-informatiesysteem onderwijs- 
arbeidsmarkt zullen worden gemaakt. Hierbij kan eveneens gewezen worden op het ontwikkelen van een geautomatiseerd informatieprodukt met betrekking tot de monitoring van de bestemming van schoolverlaters, de arbeidsmarktprognoses en andere voor het arbeidsvoorzieningsbeleid relevante gegevens.

Schema III Overzicht mogelijke informatleprodukten voor de verschillende gebrulksdoelen en gebruikersgroepen

\begin{tabular}{|c|c|c|}
\hline Gebruikersgroep & Gebruiksdoel & Produkten \\
\hline scholen & schoolmanagement & $\begin{array}{l}\text { - standaardschool rapportage } \\
\text { - maatwerkrapportages } \\
\text { - regionale en landel ijke } \\
\text { standaardrapporten } \\
\text { - geautomat } 1 \text { seerd informatieprodukt }\end{array}$ \\
\hline $\begin{array}{l}\text { school decanen, } \\
\text { arbeldsbureaus, } \\
\text { LDC/RDC'S, } \\
\text { beroepskeuze-adv1 seurs }\end{array}$ & $\begin{array}{l}\text { studie- en beroepskeuze- } \\
\text { voorlichting }\end{array}$ & $\begin{array}{l}\text { - standaard school rapportage } \\
\text { - regionale en landel ijke } \\
\text { standaardrapporten } \\
\text { - I-See! } \\
\text { - schoolverlatersbrlef } \\
\text { - diverse voorlichting scampagines }\end{array}$ \\
\hline $\begin{array}{l}\text { Ministerie van } \\
\text { Onderwijs en Weten- } \\
\text { schappen, Provinciale en } \\
\text { gemeentel ijke overheden, } \\
\text { onderwijsorganisaties }\end{array}$ & onderwijsbeleid & $\begin{array}{l}\text { - regionale en landelijke } \\
\text { standaardrapporten } \\
\text { - arbeldsmarktplaatjes } \\
\text { - ROA- Informatlesysteem } \\
\text { - geautomatiseerd informat leprodukt }\end{array}$ \\
\hline $\begin{array}{l}\text { CBA/RBA's } \\
\text { Arbeidsbureaus } \\
\text { CVV's } \\
\text { Vrouw en Werkwinkels, } \\
\text { e.d. }\end{array}$ & arbeldsvoorzleningsbeleid & $\begin{array}{l}\text { - reglonale en landelifke } \\
\text { standaardrapporten } \\
\text { - maatwerkrapportage t.b.v. } \\
\text { arbeldsvoorzlening } \\
\text { - arbeidsmarktprognoses ROA } \\
\text { - geautomati seerd informatleprodukt }\end{array}$ \\
\hline $\begin{array}{l}\text { bedrijfsleven, } \\
\text { overheden, e.d. }\end{array}$ & $\begin{array}{l}\text { personeelsbeleid } \\
\text { (wervingsbeleid) }\end{array}$ & $\begin{array}{l}\text { - reglonale en standaardrapporten } \\
\text { - maatwerkrapportages voor sub-regios e.d. } \\
\text { - geautomatiseerd informatieprodukt }\end{array}$ \\
\hline
\end{tabular}

Ook voor het bedrijfsleven kunnen de diverse regionale en landelijke standaardrapportages een nuttige informatiebron vormen over de regionale werkloosheid naar vakrichting, de concurrerende vraag op de arbeidsmarkt, de regionale mobiliteit van de schoolverlaters, e.d. Daarnaast zouden op verzoek van bedrijven bepaalde matwerkrapportages kunnen worden samengesteld. Daarbij kan worden gedacht aan een rapportage over een bepaalde sub-regio, een verbij- 
zondering van bijvoorbeeld de verschiliende aspecten van de kwalitatieve aanslutting of de gevolgde cursussen in een bepalde bedrijfstak, e.d.. Mogelijk kan ook voor deze gebruikersgroep een geautomatiseerd informatieprodukt worden ontwikkeld in aansluiting op het ARBVO-project Primaire en Gemeenschappelijke Informatievoorziening (PGI).

Schema III geeft een overzicht van de genoemde informatieprodukten voor de diverse gebruiksdoelen en gebruikersgroepen.

\subsection{Onderzoekopzet}

\subsubsection{Aspecten van de onderzoekopzet.}

Alvorens de algehele onderzoekopzet zal worden besproken, zal in deze paragraaf eerst worden ingegaan op enkele aspecten van de onderzoekopzet, waarover bij voortzetting van het RUBS-project besluitvorming zal moeten plaatsvinden. Daarbij gaat het om de volgende punten:

- het meetmoment;

- de frequentie;

- herhalingsenquête;

- afbakening van de onderzoekpopulatie;

- het meetinstrument;

- aanvullende vragen;

- responsbewaking;

- al of niet verplichte deelname scholen.

Bij de keuze van het meetmoment geldt een aantal overwegingen. Enerzijds mag de periode tussen het moment warop de leerlingen de school verlaten en het meetmoment niet te kort zijn, omdat anders het 'zoekproces' van de schoolverlaters op de arbeidsmarkt onvoldoende is uitgekristalliseerd. Het meetmoment in de maand oktober, dat van het CORO/LCAS-onderzoek wordt aangehouden, is vanuit dit oogpunt minder gelukkig. Anderzijds dient de periode tussen het moment van schoolverlaten en het meetmoment ook weer niet te lang te zijn, vanwege het tijdstip warop de gegevens dan beschikbaar zullen komen voor studie- en beroepskeuzebeslissingen. Hierbij moet bovendien rekening worden gehouden met de gebruikelijke vertraging bij het beschikbaar komen van de onderzoekresultaten. Vanuit dit oogpunt zou het wenselijk zijn als de resultaten beschikbaar zouden zijn op het moment dat de studie- en beroepskeuzevoorlichtingsactiviteit in het daarop volgende schooljaar plaats- 
vinden. Daarnaast is het van belang dat de schooladministratie niet in een piekperiode wordt belast met de activiteiten die voor RUBS moeten worden verricht ${ }^{6}$. Tenslotte is het gewenst rekening te houden met het beleidsvoornemen in het kader van de Jeugdwerkgarantiewet, om schoolverlaters die een half jaar na het beëindigen van hun opleiding niet op eigen kracht werk hebben gevonden, een arbeidsplaats aan te bieden. Dit laatste zou er voor pleiten de besteming van de schoolverlaters op de arbeidsmarkt te meten voordat een dergelijke plaatsing heeft plaatsgevonden.

Op basis van bovenstaande overwegingen resulteren er twee opties voor het metingsmoment: de maanden januari of april in het volgende schooljaar. Bij een meting in januari zou het mogelijk moeten zijn om in augustus over de RUBS-uitkomsten te rapporteren, hetgeen de scholen in staat stelt om bij hun wervingsactiviteiten e.d. in het najaar er gebruik van te maken. Bij een meting in april is het wenselijk dat het dataverwerkingsproces met een maand wordt verkort, zodat de gegevens in oktober beschikbaar komen voor de diverse voorlichtingsactiviteiten die vanaf dat tijdstip plaatsvinden. Zoals opgemerkt, zou een meting in januari bovendien goed aansluiten op de voorgenomen Jeugdwerkgarantiewet voor schoolverlaters. Bij een meting in april is het echter ook heel goed mogelijk te traceren of een schoolverlater werkzaam is in het kader van de Jeugdwerkgarantiewet. Bij een meting in april zou ook kunnen worden overwogen bepaalde aspecten van de Jeugdwerkgarantiewet te evalueren op basis van de RUBS-enquête. Een meting in april zou tevens het voordeel hebben dat de eerste fase van het zoekproces op de arbeidsmarkt voor veel schoolverlaters zal zijn afgesloten (zie Meesters en Huson, 1990). Een dergelijk meetmoment is bovendien gangbaar in het buitenland (zie ook Van Laarhoven 1990) en biedt daarmee ook perspectieven voor eventuele toekomstige internationale vergelijkingen. Voor de schooladministraties brengt dit meetmoment geen problemen met zich mee, in de zin dat extra activiteiten moeten worden verricht ten tijde van een piekperiode in de werkzaamheden: Bij een enquêtering in april zullen de scholen reeds in de maand januari de adressen van de schoolverlaters moeten opleveren. Op basis van bovengenoemde overwegingen lijkt de maand april het meest geschikte meetmoment voor een eerste-bestermingsenquête.

Het RUBS-onderzoek beoogt de eerste besteming van schoolverlaters periodiek

6. In paragraaf 4.4.2. zal overigens worden voorgesteld deze belasting tot een minimum te beperken, door de verzending e.d. niet vanuit de scholen te doen plaatsvinden. 
te pellen. Dit betekent dat met enige regelmat een nieuw cohort schoolverlaters moet worden geënquêteerd. Naast de noodzaak de gegevens over de schoolverlaters telkens te actualiseren, is een dergelijke periodieke meting ook van belang voor het in beeld kunnen brengen van eventuele ontwikkelingstrends. De vraag doet zich hierbij voor met welke frequentie de meting dient plaats te vinden. Daarbij gaat het in feite om de keuze tussen een jaarlijkse of een tweejaarlijkse meting. Het grote voordeel van een jaarlijkse meting is dat men telkens over de meest recente informatie beschikt. Bovendien is in dat geval de organisatorische continuiteit het gemakkelijkst te warborgen en is er sprake van een meer gelijkmatige belasting van de onderzoekcapaciteit. Tevens zal een jaarlijkse meting de koppelbaarheid van de uitkomsten aan het huidige basismateriaal voor de landelijke arbeidsmarktprognoses, de Enquête Beroepsbevolking van het CBS, waarschijnlijk vergemakkelijken. Tenslotte heeft jaarlijkse enquêtering bij de in paragraaf 4.3.2. voorgestelde onderzoekopzet het voordeel dat de frequentie waarmee individuele scholen gerapporteerd kunnen worden over de bestemming van hun schoolverlaters niet te laag komt te liggen. Daar staat echter tegenover dat een tweejaarlijkse enquêtering lagere kosten met zich mee zal brengen, met name wanneer de bij het RUBS-project ingeschakelde projectmedewerkers in het tussenliggende jaar voor andere activiteiten kunnen worden ingezet. Omdat vooralsnog onduidelijk is hoe groot de verschuivingen in de besteming van schoolverlaters van jaar tot jaar zullen zijn, gaat de voorkeur uit naar een jaarlijkse meting. Na enkele jaren zou dan kunnen worden nagegaan of een tweejaarlijkse meting mogelijk is.

Dit laatste zou het mogelijk maken binnen de bestaande organisatiestructuur na een aantal jaren de eerste bestemmingsenquête van de schoolverlaters aan te vullen met een of meerdere herhalingsenquêtes. Drie à vier jaar na het moment van schoolverlaten zou daarbij een geschikt moment zijn voor een tweede meting. Een dergelijke 'follow-up' meting makt ook onderdeel uit van veel schoolverlatersonderzoek in binnen- en buitenland. Temeer daar de SMVOschoolverlatersenquête van het CBS recent is beëindigd, zou een dergelijke vervolgmeting in een belangrijke lacune in de kennis over de loopbaanpatronen van schoolverlaters in ons land kunnen voorzien. Van Laarhoven $(1990, p .30)$ laat zien hoe de cohortstructuur van het RUBS-project er uit zou kunnen gaan zien bij de inpassing van een follow-up enquête in het RUBS-project.

De inbouw van een herhalingsenquête in het RUBS-project impliceert dat de adressenbestanden van de schoolverlaters na de eerste meting moeten worden 
bewaard. Er moet dan voldaan worden aan de in de Wet Persoonsregistratie gestelde bepalingen ten aanzien van het aanhouden van een dergelijk adressenbestand. Het is in dit kader noodzakelijk dat er sprake is van een instantie die als 'houder' van het bestand optreedt. Het ligt voor de hand dit houderschap te centraliseren en onder te brengen bij een centraal beheerorgaan van het RUBS-project. In paragraaf 4.4. zal op het laatste verder worden ingegaan.

Bij de afbakening van de onderzoekpopulatie zal, zoals in paragraaf 2.3. reeds werd aangegeven, om onderzoektechnische redenen uitgegaan moeten worden van een ruime definitie van het begrip schoolverlater. Bovendien is het vanwege de grote beleidsrelevantie van de 'drop-out' problematiek wenselijk nast de gediplomeerde schoolverlaters ook de ongediplomeerde schoolverlaters in het onderzoek te betrekken.

Ook doet zich de vraag voor in hoeverre de RUBS-enquête zich tot bepaalde schooltypen zou moeten beperken. Omdat het RUBS-project is gericht op de aansluiting tussen onderwijs en arbeidsmarkt heeft het beroepsonderwijs waarschijnlijk de hoogste prioriteit. De uitstroom van het algemeen voortgezet onderwijs naar de arbeidsmarkt is echter niet onaanzienlijk en er kunnen bij dit onderwijstype voor zowel drop-outs als gediplomeerde schoolverlaters grote aansluitingsproblemen op de arbeidsmarkt optreden. Daarom lijkt het ons toch wenselijk ook deze schooltypen in het onderzoek te betrekken.

Onder andere vanuit de begeleidingscommissie is de suggestie gedaan ook de 'schoolverlaters' van het leerlingwezen in het kader van het RUBS-project te enquêteren, omdat het leerlingwezen een belangrijke schakel vormt in de initiële beroepsopleiding van jongeren. De vraag doet zich hierbij echter voor in hoeverre het in beeld krijgen van de arbeidsmarktbesterming van de 'schoolverlaters' van het leerlingwezen niet sterk in het verlengde ligt van de omvangrijke dataverzamelingsactiviteiten vanuit de Regionale Organen voor het Leerlingwezen. Desalniettemin is het raadzaam een eventueel onderzoek naar de bestemming van de 'schoolverlaters' van het leerlingwezen inhoudelijk af te stemmen op de RUBS-enquête, zodat de uitkomsten vergelijkbaar zijn met en gekoppeld kunnen worden aan de RUBS-uitkomsten.

Overwogen zou kunnen worden het Hoger Onderwijs buiten de onderzoekpopulatie te houden. Dit geldt met name voor het Wetenschappelijk Onderwijs. Hiervoor is een aantal argumenten aan te voeren. In de eerste plaats zijn verschil- 
lende instellingen voor Hoger onderwijs reeds betrokken bij grootschalig onderzoek naar de besteming van de afgestudeerden. De onderzoeken van het NILI, KIVI en NIRIA zijn hiervan de meest in het oog springende voorbeelden (zie ook Van Dam, De Grip en Heijke, 1988 en 1990 en Van Dam en Mortier, 1990). In de tweede plaats is met name bij het Wetenschappelijk Onderwijs het aantal instellingen dusdanig klein dat een regionalisering van de onderzoekresultaten meestal neer zal komen op het publiceren van de gegevens van een individuele instelling. In de derde plaats is het aantal afstudeerrichtingen, vooral in het Wetenschappelijk Onderwijs, dusdanig groot dat het opnemen van dit onderwijs in het RUBS-project de onderzoekorganisatie onevenredig zwaar zal belasten. Tenslotte pleit het feit dat er een grote spreiding is in het tijdstip van afstuderen voor een aparte benadering van de afgestudeerden van met name het Wetenschappelijk Onderwijs. Vanzelfsprekend is het daarbij van groot belang dat de resultaten van het onderzoek onder afgestudeerden uit het Hoger Onderwijs vergelijkbaar zijn met en koppelbaar zijn aan de uitkomsten van de RUBS-enquête. Dit noodzaakt tot een gecoördineerde aanpak. De door het ROA ontwikkelde 'arbeidsmarktscanner' (Van Dam, Heijke en Ramaekers, 1989) zou hiervoor een geschikt meetinstrument kunnen zijn.

Vanwege de aard en de omvang van de gevraagde informatie en de positieve ervaringen die hiermee zijn opgedaan in het RUBS-pilotproject, lijkt de keuze van een schriftelijke enquête op het huisadres terecht als meetinstrument te zijn gekozen. Temeer daar een dergelijk meetinstrument relatief goedkoop is ten opzichte van een mondelinge enquêtering op het huisadres en een telefonische enquête mogelifk tot een lagere respons zal leiden (zie ook Van Laarhoven, 1990).

Vanuit het besef dat een grootschalige RUBS-meting tot een belangrijke concentratie van het schoolverlatersonderzoek in ons land zal leiden, is het gewenst om naast het beperkte aantal vragen dat standaard deel uit maakt van de vragenlijst, uitdrukkelijk mogelijkheden te creeëren voor het stellen van aanvullende vragen. vanuit verschillende potentiële gebruikersgroepen is gewezen op het belang van deze mogelijkheid. Daarbij kan worden gedacht aan zowel vragen die niet bij iedere meting aan al le geënquêteerden worden gesteld, als vragen die alleen aan de schoolverlaters van een bepaalde school of opleidingstype, of in een bepaalde regio worden gesteld.

Responsbewaking vormt een cruciaal aandachtspunt bij een onderzoekproject 
als de RUBS-enquête. Zoals in hoofdstuk 2 werd beschreven, kunnen de huidige vorm en inhoud van de vragenlijst in dit opzicht positief worden beoordeeld. ook blijkt het schriftelijk rappel een belangrijke rol te hebben gespeeld bij het behalen van een bevredigend responspercentage. Onduidelijk is in hoeverre het feit dat de vragenlijsten door de school zijn verstuurd de respons in positieve zin heeft beinvloed. In overeensteming met de verwachtingen, is de respons onder de ongediplomeerde schoolverlaters wel problematisch. Overwogen zou kunnen worden of er bij deze groep ook een telefonische rappellering moet plaatsvinden.

Van groot belang is natuurlijk ook in hoeverre er sprake is van een selectieve non-respons. De ervaringen van het pilotproject wijzen inderdaad in de richting van enige selectiviteit. De enquête-uitkomsten leveren met name een onderschatting op van het percentage werkloze ongediplomeerde schoolverlaters en een overschatting van het percentage ongediplomeerde schoolverlaters dat aan een vervolgopleiding is begonnen. (zie Waslander en Van Laarhoven 1990). Bij een voortzetting van het RUBS-project dient derhalve uitdrukkelijk de mogelijkheid voor een herweging van de onderzoekresultaten te worden gecreëerd. Dit vereist ook een telefonisch non-respons onderzoek van enige omvang, op basis waarvan een dergelijke herweging kan plaatsvinden.

Zowel vanuit organisatorisch oogpunt (steekproeftrekking e.d.), als vanuit het oogpunt van representativiteit is het van belang dat zoveel mogelijk scholen bereid zijn in het RUBS-project te participeren. Men kan zich afvragen in hoeverre het wenselijk is om de deelname aan het RUBS-schoolverlatersonderzoek voor scholen verplicht te stellen. Een dergelijke verplichtstelling lijkt in eerste instantie enigszins in strijd met het voornemen van het Ministerie van Onderwijs en Wetenschappen om individuele scholen grotere beleidsvrijheden te geven. Aan de andere kant zou men, zoals reeds eerder werd opgemerkt, kunnen stellen dat juist het vergroten van de beleidsvrijheid van individuele scholen, het gewenst makt dat scholen ook informatie verschaffen over de kwaliteit van het gegeven onderwijs door bijvoorbeeld in een jaarverslag hierover verantwoording af te leggen. De uitkomsten van de RUBS-enquête zouden daar een onderdeel van kunnen vormen. Ook zou overwogen kunnen worden bepaalde 'incentives' voor de scholen te creëren voor de deelname aan RUBS. Daarbij kan onder andere worden gedacht aan de eis dat verzoeken om capaciteitsuitbreiding of het opzetten van nieuwe vakrichtingen onderbouwd worden met een 'arbeidsmarktplaatje' dat mede gebaseerd is op uitkomsten van de RUBS-enquête. 


\subsubsection{De_algehele onderzoekopzet}

Vanzelfsprekend moet de toekomstige onderzoekopzet zo goed mogelijk worden afgestemd op de in de vorige paragraaf geschetste mogelijke gebruiksdoelen van de RUBS-schoolverlatersenquête. Daarnaast zullen ook de ervaringen die het afgelopen jaar zijn opgedaan met het RUBS-pilotproject en de kosten die verbonden zijn aan het schoolverlatersonderzoek, een belangrijke leidraad vormen voor beslissingen ten aanzien van de toekomstige onderzoekopzet.

Vanuit het RUBS-pilotproject is een drietal alternatieven naar voren gekomen voor de algehele opzet van het schoolverlatersonderzoek. Het gaat daarbij om de volgende alternatieven:

1. Een landelijke steekproef onder de schoolverlaters.

2. Een integrale enquêtering van de schoolverlaters.

3. Een roterend panel van scholen waarbij, van de in een bepaald jaar in het onderzoek opgenomen scholen, alle schoolverlaters worden geënquêteerd.

\section{Landelijke steekproef}

Het RION bepleit in zijn voorstel voor een toekomstige onderzoekopzet van RUBS, het eerstgenoemde alternatief. Uitgaande van een totale populatie van jaarlijks ruim 400.000 schoolverlaters (in ruime zin) zou, op basis van de 'lijsten van scholen' of de 'integrale leerlingentelling' van het Ministerie van Onderwijs en Wetenschappen, een steekproef kunnen worden getrokken uit de totale schoolverlaterspopulatie. Het RION denkt daarbij aan een steekproef van circa 60.000 gediplomeerde en 36.000 ongediplomeerde schoolverlaters. Bij een respons van ongeveer $65 \%$ resulteren dan analysebestanden van circa 40.000 gediplomeerden en 24.000 voortijdige schoolverlaters (Van Laarhoven, $1990)$.

Een dergel ijke enquêtering makt het mogelijk voor ongeveer 500 deelpopulaties gediplomeerde en 300 deelpopulaties ongediplomeerde schoolverlaters, met enige nauwkeurigheid uitspraken te doen over de besteming van schoolverlaters op het niveau van globale categorieën als vervolgonderwijs, werk op of onder het opleidingsniveau, werk in aansluitende of niet aansluitende sectoren, werkloosheid, e.d. Ten aanzien van de gediplomeerde schoolverlaters is het bij deze enquête-omvang mogelijk op provinciaal niveau circa 50 opleidings- 
categorieën te onderscheiden 7 . Op landelijk niveau is het evenwel mogelijk de uitkomsten te differentiëren naar een groter aantal opleidingstypen c.q. vakrichtingen. Op RBA-niveau is het daarentegen bij een dergelijke steekproefomvang slechts mogelijk om hooguit 20 opleidingscategorieën te onderscheiden.

\section{Integrale enquêtering}

Een tweede alternatief is het integraal benaderen van de totale populatie van ruim 400.000 schoolverlaters. Een dergelijke aanpak impliceert een enquêtering die het vier-tot vijfvoudige bedraagt van de enquête-omvang bij het eerste alternatief. Een integrale enquêtering maakt het mogelijk in verregaande mate te differentiëren naar zowel regio als opleidingstype, c.q. vakrichting. In principe zou het daarbij mogelijk zijn de uitkomsten te presenteren op het niveau van bijvoorbeeld de ruim 540 opleidingen c.q. vakrichtingen die het afgelopen jaar binnen het RUBS-pilotproject zijn onderscheiden. Ook op RBA-niveau zou een dergelijke verregaande differentiatie in principe mogelijk zijn. Daarbij doet zich echter wel het probleem voor dat in dat geval de uitkomsten nogal eens betrekking zullen hebben op een individuele school, hetgeen publicatie van de uitkomsten mogelijk bezwaarlijk kan maken.

\section{Roterend panel van scholen}

Het derde alternatief is min of meer een tussenvorm van de eerste twee alternatieven. Er wordt in dit geval niet, zoals bij het eerstgenoemde alternatief, een steekproef getrokken uit de totale populatie schoolverlaters, maar een steekproef uit de diverse (afdelingen van) scholen. Van de scholen die in een bepald jaar in de RUBS-enquête zijn vertegenwoordigd zullen dan alle schoolverlaters worden geënquêteerd.

Een dergelijke 'clustering' bij de steekproeftrekking impliceert dat bij een gegeven omvang van de enquête, de nauwkeurigheid van de steekproefuitkomsten geringer is. De grootte van dit zogenaamde 'designeffect' is afhankelijk van de mate warin de bestemming van de schoolverlaters in een bepaalde opleidingsrichting uiteenloopt tussen verschillende scholen. (zie ook Van Laarhoven,

7. Hierbij wordt er van uitgegaan dat een aantal opleiding en regio combinaties niet voorkomen. 
1990). Op voorhand is hierover geen uitspraak te doen. Wel kan worden vastgesteld dat bij een dergelijke aanpak een grotere steekproefomvang is vereist dan bij het eerstgenoemde alternatief. Dit geldt des te meer daar wordt voorgesteld een verregaande differentiatie naar opleidingstype en regio mogelijk te maken. Daar een verregaande differentiatie naar opleiding vooral van belang is voor het beroepsonderwijs, wordt voorgesteld ten aanzien van het beroepsonderwijs een relatief grotere steekproef te trekken dan bij het algemeen voorgezet onderwijs.

Concreet zou dit kunnen betekenen dat in het beroepsonderwijs jaarlijks bij circa $50 \%$ van de (afdelingen van) scholen alle schoolverlaters van die scholen worden geënquêteerd. Daarentegen zouden in het Avo, waarvoor een verregaande differentiatie minder noodzakelijk is ${ }^{8}$, bij slechts $25 \%$ van de scholen de schoolverlaters worden geënquêteerd. Bij een roterend panelonderzoek betekent dit dat de instellingen voor beroepsonderwijs gemiddeld eenmaal in de twee jaar en de Avo-scholen gemiddeld om de vier jaar in het onderzoek worden betrokken. Een dergelijke opzet impliceert een jaarlijkse steekproefomvang van in totaal circa $110.000-150.000$ gediplomeerde en circa $40.000-60.000$ ongediplomeerde schoolverlaters. Tabel 5 geeft een overzicht van de samenstelling van de te benaderen populatie.

Deze aanpak maakt het mogel1jk binnen het beroepsonderwijs in verregaande mate te differentiëren naar vakrichting. Daarbij is een zinvolle differentiatie naar opleidingstype op RBA-niveau mogelijk. Met name bij het MBO zal een verbijzondering naar RBA-regio nogal eens op problemen stuiten. De enquêteopzet zal dan in een aantal regio's alsnog neerkomen op een integrale benadering van de schoolverlaters van de desbetreffende opleidingstypen. Mede hierdoor zal de steekproefomvang bij een dergelijke opzet waarschijnlijk in de buurt komen te liggen van de bovengenoemde bovengrens van circa 200.000 schoolverlaters. Bij de ongediplomeerde schoolverlaters zal de verbijzondering naar vakrichting ook minder ver kunnen gaan dan bij de gediplomeerden. Daar de ongediplomeerden per definitie toch geen diploma van een bepaalde vakrichting hebben behaald, is het waarschijnlijk ook terecht om deze groep niet veel verder te verbijzonderen naar het opleidingstype waaruit ze zonder diploma zijn vertrokken.

8. Eventueel zou men bij de AvO-schoolverlaters kunnen differentiëren naar de aard van het gevolgde vakkenpakket. 
Tabel 5. Globale samenstelling van de steekproef (U1tgaande van een 50\%-steekproef van het beroepsonderwijs en een $25 \%$-steekproef van het AVO)*

\begin{tabular}{|c|c|c|}
\hline & Gediplomeerden & Ongediplomeerden \\
\hline Beroepsonderw1js & 72.900 & 27.900 \\
\hline waarvan LBO & 41.700 & 9.900 \\
\hline MBO & 31.200 & 18.000 \\
\hline AVo & 35.800 & 8.700 \\
\hline waarvan MAvo & 18.800 & 3.800 \\
\hline HAVO & 8.700 & 2.900 \\
\hline vwo & 8.300 & 1.200 \\
\hline HAVO/VWO & & 900 \\
\hline Totaal & 108.700 & 36.600 \\
\hline
\end{tabular}

Bron: CBS, Onderwijsmatrix 1986

* Vanwege het dalende aantal schooiverlaters zullen deze aantallen in de nablje toekomst circa $15 \%$ lager liggen.

Aan elk van de drie hier gepresenteerde alternatieven kleven voor- en nadelen. Het RION wijst op een drietal voordelen van het eerstgenoemde alternatief, een landelijke steekproef onder de totale groep schoolverlaters (Van Laarhoven, 1990):

- bij een dergelijke onderzoekopzet kan met een relatief eenvoudige organisatiestructuur worden volstaan. Op een centraal onderzoekpunt kan een steekproefkader van schoolverlatersadressen worden opgebouwd en kan de dataverzameling en -verwerking plaatsvinden;

- er hoeft slechts in geringe mate een beroep te worden gedaan op de administratie van de scholen. Er kan worden volstaan met het doorgeven van de adressen van schoolverlaters;

- de totale kosten zijn aanmerkelijk lager dan bij de beide andere alternatieven. Het RION komt op basis van een giobale schatting uit op een bedrag van circa 1 miljoen tot 1,3 miljoen gulden per jaar (Van Laarhoven, 1990). Daarbij is overigens geen rekening gehouden met de kosten van het rapporteren aan de verschillende gebruikersgroepen. Wanneer men deze kosten wel in de begroting opneemt kunnen de kosten globaal worden geschat op 2 miljoen gulden per jaar.

Aan dit alternatief kleven echter ook belangrijke nadelen. Zo is het bij een dergelijke enquête-omvang slechts in beperkte mate mogelijk op regional 
niveau te differentiëren naar opleidingstype. Op provinciaal niveau kunnen, zoals eerder is opgemerkt, slechts circa 50 opleidingscategorieën worden onderscheiden. Bovendien is het op RBA-niveau nauwelijks mogelijk op zinvolle wijze naar opleidingstype te differentiëren. Voor het opleidings- en beroepskeuzevoorlichtingssysteem I-See! betekent dit dat weliswaar op landelijk niveau een verregaande verbijzondering naar opleidingstype c.q. vakrichting mogelijk is, mar op provinciaal niveau slechts een even groot aantal opleidingscategorieën kan worden onderscheiden als momenteel op landelijk niveau binnen de arbeidsmarktmodule van I-See! het geval is. Een aantal van 50 opleidingscategorleën wordt binnen I-See! als een te hoog agregatieniveau ervaren.

Een ander belangrijk nadeel van dit alternatief is dat er geen resultaten beschikbaar komen op het niveau van de individuele school, omdat er geen 'steekproefclustering' heeft plaatsgevonden. Dit betekent dat RUBS vrijwel niet meer tegemoet kan komen aan de in paragraaf 4.2. geschetste gebruiksdoelen van het schoolmanagement. Weliswaar zullen de scholen dan nog wel informatie kunnen krijgen over hun schooltype op provinciaal niveau en de verschillende vakrichtingen op landelijk niveau, mar het is niet mogelijk een beeld te schetsen van de bestemming van de schoolverlaters van de verschillende afdelingen binnen de eigen school.

Bij de geconsulteerde beleidsinstanties op national en regional niveau werd nogal eens de voorkeur uitgesproken voor het enquêteren van de totale groep schoolverlaters. Een dergelijke integrale benadering heeft vanzelfsprekend als voordeel dat een nauwkeurig beeld kan worden verkregen van de bestemming van de schoolverlaters. Zoals eerder werd opgemerkt is het dan in principe mogelijk te verbijzonderen naar ruim 500 opleidingen c.q. vakrichtingen. Daarbij bestaat de mogelijkheid de data regionaal te verbijzonderen tot op RBA-niveau.

Een belangrijk voordeel ten opzichte van het eerstgenoemde alternatief is dat bij een integrale enquêtering de RUBS-uitkomsten ook een informatieinstrument vormen voor het schoolmanagement. Daarbij gaat het zowel om de resultaten van de eigen school, als om de mogelijkheid de verschillende scores van de diverse afdelingen binnen de school te vergelijken met de regionale of landelijke uitkomsten voor deze vakrichtingen.

Tegenover bovengenoemde voordelen van een integrale aanpak staan als nadelen 
een overbelasting van het onderzoekveld en de aanzienlijk hogere kosten. Het RION wijst op het eerste nadeel. Gesteld wordt dat een integrale benadering van de schoolverlaterspopulatie een overbelasting van het onderzoekveld (scholen en schoolverlaters) met zich meebrengt, hetgeen kan leiden tot 'veldbederf' ten koste van ander onderzoek en mogelijk tot continuiteitsproblemen bij RUBS zelf. (Van Laarhoven, 1990). Hier staat echter tegenover dat RUBS zelf in een majeure onderzoekbehoefte voorziet, waardoor een lappendeken van onderling onvergelijkbare schoolverlatersonderzoeken wordt voorkomen ${ }^{9}$.

Vanzelfsprekend is een integrale enquêtering het duurste alternatief. De hogere kosten zullen moeten worden afgewogen tegen de waarde die wordt toegekend aan de informatie die een integrale benadering toevoegt aan de informatie die de beide andere alternatieven opleveren. Ten opzichte van het eerstgenoemde alternatief, een steekproef van de schoolverlaterspopulatie, is er, zoals hierboven is uiteengezet, inderdaad sprake van belangrijke extra informatie. Enerzijds wordt een verregaande verfijning van de resultaten naar de verschillende vakrichtingen en regio's mogelijk. Anderzijds wordt het mogelijk aan de scholen te rapporteren over de bestemming e.d. van de eigen schoolverlaters.

Ten opzichte van een roterend panel onder scholen heeft een integrale benaderig als belangrijkste voordeel dat jeder jaar een beeld wordt verkregen van de besteming van de schoolverlaters van iedere school. De integrale benadering en het roterende panel verschillen niet of nauwelijks ten aanzien van de mogelijkheid te verbijzonderen naar vakrichting en regio. Een integrale enquêtering heeft echter als voordeel dat de schooladministratie de aanlevering van de adressen van de schoolverlaters eerder als een reguliere activiteit beschouwt. Met name ten aanzien van de voortijdige schoolverlaters zou het een groot voordeel zijn wanneer scholen administratief op een dergelijke dataverzameling zijn ingesteld. Een roterend panel vormt daarentegen een efficiënte aanpak wanneer het er alleen om gaat om in verregaande mate naar vakrichting en regio te kunnen verbijzonderen 10 . Bij het voorgestelde steekproefpercentage van $50 \%$ van het beroepsonderwijs, betekent een derge 1 ijke

9. Zoals reeds eerder werd opgemerkt, is het daarbij wel gewenst dat onderzoek vanuit andere onderzoekvragen dan die van RUBS, door middel van aanvullende vragen in principe kan aanhaken bij de RUBS-enquête.

10. Door de veel grotere steekproefomvang brengt een panel van scholen natuurlijk wel aanzienlijk meer kosten met zich mee dan het alternatief van de steekproef onder schoolverlaters. 
aanpak echter dat een individuele school niet ieder jaar een beeld krijgt van de besteming van de eigen schoolverlaters, maar slechts éénmaal in de twee jaar. Voor de AVO scholen zou dit bij het voorgestelde steekproefpercentage van $25 \%$ slechts één maal in de vier jaar mogelijk zijn. Daar staat tegenover dat men voor de tussenliggende jaren wel een beeld krijgt van eventuele regionale of landelijke verschuivingen in de besterming van schoolverlaters e.d., verbijzonderd naar de vakrichtingen zoals die ook binnen de eigen instelling voorkomen.

In vergelijking met de integrale enquêtering brengt een roterend panel van scholen wel enige complicaties met zich mee ten aanzien van de steekproeftrekking, mede als gevolg van de noodzaak de genoemde 'design-effecten' te voorkomen. Bovendien is het mogelijk dat binnen een school bepaalde vakrichtingen om steekproeftechnische redenen in andere jaren aan RUBS zullen moeten mee doen dan andere afdelingen. Van het door het RION genoemde probleem dat scholen erg lang moeten wachten voordat ze in een bepaald jaar weer in het onderzoek participeren (Van Laarhoven, 1990, p. 26/27), is ons inziens geen sprake wanneer de scholen met een frequentie van éénmaal in de twee jaar (beroepsonderwijs) of éénmaal in de vier jaar (AVO) in het onderzoek participeren.

Naast de geringere kosten heeft een roterend panel van scholen als voordeel ten opzichte van een integrale enquêtering dat het bovengenoemde 'veldbederf' enigszins geringer zal zijn. Desalniettemin zal ook bij dit alternatief de bereidheid van scholen on deel te nemen aan andere onderzoeken met betrekking tot de aansiuitingsproblematiek tussen onderwijs en arbeidsmarkt waarschijnlijk afnemen. Daar staat echter tegenover dat de RUBS-enquête juist bedoeld is om enige uniformering aan te brengen in de lappendeken van ad hoc onderzoeken op dit terrein, die het onmogelijk makt de resultaten onderling te vergelijken en de aansluitingsproblematiek bij schoolverlaters op continue basis te monitoren. Veel beter is het ons inziens om verschillende andere al of niet verwante vraagstellingen, die men aan schoolverlaters zou willen voorleggen, op ad hoc basis aan de vragenlijst toe te voegen. Een dergelijke aanpak wordt meestal aangeduid als 'piggy-backing'. Dergelijke aanvullende vragen zullen doorgaans betrekking hebben op slechts een beperkt deel van de totale schoolverlaterspopulatie. Daarbij kan men denken aan aanvullende vragen voor de schoolverlaters van een bepaalde school, van een bepald schooltype, of in een bepaalde regio. 
De hierboven naar voren gebrachte argumenten pro en contra de drie voorgestelde alternatieven tegen elkaar afwegend, bepleiten wij een keuze voor een roterend panel onder scholen of een integrale enquêtering van de schoolverlaters. Het belangrijkste argument is dat alleen deze twee onderzoekopzetten het mogelijk maken om de RUBS-uitkomsten in verregaande mate te verbijzonderen naar zowel de verschillende vakrichtingen als regio's. Voor alle vier in paragraaf 4.2. genoemde gebruiksdoelen is een dergelijke desaggregatie van de uitkomsten van groot belang. In de tweede plaats is het alleen bij deze twee onderzoekopzetten mogelijk te rapporteren aan het schoolmanagement over de schoolverlaters van de eigen insteliing.

De integrale aanpak heeft daarbij het voordeel dat iedere school jaarlijks inzicht krijgt in de bestemming van de schoolverlaters, terwijl dit bijeen roterend panel onder scholen slechts eenmal in de twee of vier jaar het geval is. Deze meerwaarde van een integrale enquêtering moet worden afgewogen tegen de extra kosten die een integrale meting met zich meebrengt en het mogelijk grotere veldbederf. Daar staat tegenover dat de steekproeftrekking bij een roterend panel van scholen complicaties met zich mee kan brengen, die er toe kunnen leiden dat, met name bij het MBO, de aanpak voor nogal wat richtingen toch zou opschuiven in de richting van een integrale benadering van de schoolverlaters. Daarbij moet worden bedacht dat de hier gegeven concrete invulling van de onderzoekvariant van een roterend panel slechts een voorbeeldfunctie heeft. In principe kan voor ieder schooltype (AVO,LBO, en MBO) afzonderlijk worden bepald of het onderzoek het karakter moet krijgen van een roterend panel onder scholen of dat gekozen wordt voor een integrale benadering van de schoolverlaters.

\subsection{Mogel ijke organisatie- en financieringsstructuur}

\subsubsection{Afbakening van activiteiten}

De organisatiestructuur van het RUBS-pilotproject kenmerkte zich, zoals in hoofdstuk 2 reeds werd uiteengezet, door een grote autonomie van de participerende COA's. Deze autonomie betrof zowel het al of niet participeren in het RUBS-project, als de keuze van de schooltypen die in de eigen regio werden geënquêteerd, de opdrachtverlening voor de data-invoer en -verwerking, het drukken van de vragenlijsten, de wijze van rapporteren, etcetera. Een dergelijke decentrale aanpak makt een representatieve enquêtering onmogelijk 
en is ten aanzien van de uitvoering inefficiënt. De verantwoordelijkheid met betrekking tot de opzet en de invulling van de jaarlijkse steekproef, i.c. de samenstelling van het panel van scholen, dient derhalve centraal op nationaal niveau te worden gesitueerd.

De volgende activiteiten zullen daarbij om onderzoektechnische of -organisatorische redenen op het centrale niveau moeten plaatsvinden:

- vaststellen samenstelling panel en jaarlijkse steekproeftrekking;

- vaststellen inhoud landelijke vragenlijst;

- het drukken van de vragenlijsten;

- coördinatie uitvoering enquête;

- algehele kwaliteitsbewaking;

- contractuele aspecten ten aanzien van regionale uitvoering en participatie scholen;

- scholing en advisering ten behoeve van regionale uitvoering;

- ontwikkelen en vaststellen classificatiesystemen;

- data-invoer en -bewerking;

- verwerken non-respons onderzoek;

- eventueel herwegen uitkomsten bij disproportionele stratificatie steekproef en op basis van uitkomsten van non-responsanalyse;

- ontwikkelen databases en databeheer;

- opleveren standaardtabellen ten behoeve van school-en regionale rapportage;

- landelijke rapportages en voorlichting;

- produktontwikkeling;

- projectevaiuatie.

Het betreft hier overigens vrijwel allemal activiteiten die ook in het RUBS pilotproject niet door individuele COA's zelf zijn verricht, en de meeste COA's ook niet zelf op zich zouden willen nemen.

Daarentegen is het waarschijnlijk efficiënt om de verschillende activiteiten ten aanzien van de regionale uitvoering en organisatie van de enquêtering op regionaal ntveau te situeren. De huidige COA's c.q. de toekomstige Regionale Dienstverlenende Centra (RDC's) lijken daarbij de aangewezen instanties. Daarbij geidt als voorwarde dat alle COA's c.q. RDC's in het RUBS-project participeren.

Overwogen zou kunnen worden dat de uitvoerende taken geheel voor rekening komen van de participerende scholen. Een dergelijke aanpak heeft echter 
belangrijke nadelen. In de eerste plaats zou hierdoor de objectiviteit van de RUBS-enquête in twijfel kunnen worden getrokken. In de tweede plaats betekent een dergelijke aanpak dat er een kwaliteitsverlies bij de dataverzameling kan optreden. In de derde plaats brengt deze aanpak een aanzienlijke belasting van de schooladministratie met zich mee. Het laatste leidde er in net pilotproject onder andere toe dat scholen zich niet konden houden aan de geplande tijdstippen van verzending, hetgeen ongewenste vertragingen met zich mee bracht. Tenslotte brengt een dergelijke verregaande decentralisering van de dataverzameling naar alle waarschijnijjkheid nogal wat organisatorische problemen met zich mee ten aanzien van de totstandkoming van de landelijke databank.

In aansluiting op de taakstelling van de huidige COA's c.q. de toekomstige RDC's ligt het voor de hand ook de regionale informatie-verstrekking aan de verschillende doelgroepen vanuit de verschillende regio's te doen plaatsvinden.

Op regional niveau zullen derhalve de volgende activiteiten moeten worden verricht:

- onderhouden contacten met scholen ten behoeve van de opbouw van een adressenbestand van schoolverlaters;

- verzenden vragenlijsten en schriftelijke rappellering;

- informatieverstrekking aan scholen en bespreking RUBS-uitkomsten met het schoolmanagement;

- informatieverstrekking aan andere doelgroepen binnen de regio;

- produktontwikkeling mede op basis van het opnemen van aanvullende vragen in de (regionale) RUBS-enquête.

Bij de vaststelling van de activiteiten op regional niveau, die door de COA's of RDC's zouden moeten worden verzorgd, moet worden gekeken naar enerzijds de afbakening van de werkzaamheden die op centraal niveau plaatsvinden en anderzijds de afbakening van de werkzaamheden die door de scholen zelf zouden kunnen worden verricht.

De taakafbakening tussen de COA's/RDC's en de scholen gaat met name om de vraag of de vragenlijsten door de schooladministraties of door de COA's/RDC's moeten worden verstuurd. Daarbij gat het om zowel de eerste verzending van de enquêteformulieren als de rappellering. Het afgelopen jaar heeft de verzending van de enquêtes vanuit de scholen plaatsgevonden. Deze aanpak impliceerde doorgaans dat de scholen de verzendkosten voor hun rekening namen. 
Nadeel van deze aanpak is dat, zoals hierboven reeds werd opgemerkt, er waarschijnlijk een kwaliteltsverlies bij de dataverzameling optreedt. Omdat deze aanpak aanleiding gaf tot aanzienlijke communicatiestromen tussen COA's en scholen, en ook nogal wat coördinerende activiteiten van de COA's met zich meebracht, moet worden overwogen het verzenden van de enquête en de rappellering in de toekomst door de COA's/RDC's te laten verzorgen.

In principe zou de rappellering ook op centraal niveau kunnen plaatsvinden. Uitvoering hiervan door de COA's/RDC's heeft als voordeel dat het regionale adressenbestand alleen hoeft te worden uitgewisseld tussen de scholen en de desbetreffende COA/RDC.

We zullen nu ingaan op de afbakening van de werkzaamheden van de COA's/RDC's met de activiteiten op centraal niveau. Hierbij doet zich een aantal grensgevalien voor van activiteiten waarvan niet a priori om onderzoektechnische of -organisatorische redenen gesteld kan worden dat deze zonder meer op centraal niveau dienen plaats te vinden. Het gaat daarbij om de volgende activiteiten:

- schriftelijke rappellering;

- non-respons onderzoek;

- standaardrapportage aan scholen;

- regionale standaardrapportage.

Op het eerste punt is hierboven reeds ingegaan. Voorgesteld wordt de schriftelijke rappellering te laten verzorgen door de COA's/RDC's. Zoals in hoofdstuk 2 werd opgemerkt hebben de meeste COA's in het kader van het RUBS-pilotproject op relatief bescheiden schaal een telefonisch non-respons onderzoek uitgevoerd op basis van een kernvragenlijst. Een dergelijk non-respons onderzoek is essentieel om zekerheid te krijgen over de representativiteit van de uitkomsten van het onderzoek. Indien degenen die zorg dragen voor de regionale uitvoering van de RUBS-enquête goed geinstrueerd worden over de wijze van uitvoering van het non-respons onderzoek, lijkt het verantwoord ook op dit punt de dataverzameling te decentraliseren.

In het RUBS-pilotproject verzorgden de COA's ook de standaardrapportages aan de scholen. Zoals in hoofdstuk 2 werd uiteengezet, werd daarbij volstaan met het weergeven van de standaardteksten, waarin de bedoeling van de verschillende tabellen en grafieken werd toegelicht. Door het grote aantal scholen en vakrichtingen/sectoren binnen de instellingen waarvoor een standaardrapportage moet worden opgesteld, is een dergelijke aanpak ook het meest effi- 
ciënt. Het ligt dan wel voor de hand de standaardteksten op centraal niveau toe te voegen aan de standaardtabellen. Deze aanpak heeft bovendien als voordeel dat de regionale en landelijke gegevens, waarmee een school de uitkomsten van de eigen instelling kan vergelijken, direct op centraal niveau in de meeste standaardrapportages zijn opgenomen.

In het RUBS-pilotproject verzorgde een aantal COA's zelf hun regionale standaardrapportages voor de verschillende opleidingstypen. Enkele andere COA's besteedden deze activiteiten daarentegen uit aan min of meer gespecialiseerde onderzoekinstituten. Op zichzelf hoeft het geen bezwaar te zijn dat er binnen de diverse regio's op uiteenlopende wijze wordt gerapporteerd, omdat op deze wijze kan worden ingespeeld op eventuele specifieke regionale behoeften. Een alternatief kan echter zijn om toch op centraal niveau de regionale standaardrapportages te verzorgen, waarbij deze als basis c.q. als richtsnoer zouden kunnen dienen voor verschillende aanvullende regionale rapporten die zijn gericht op de specifieke regionale behoeften.

Schema IV geeft een overzicht van de hierboven voorgestelde taakverdeling tussen de scholen, de regionale organisaties en de landelijke organisatie.

\subsubsection{Centrale beheersinstantie}

In paragraaf 4.4.1. werd een opsoming gegeven van de verschillende activiteiten die om onderzoektechnische of -organisatorische redenen op centraal niveau moeten plaatsvinden. Het is wenselijk deze activiteiten te laten verrichten vanuit een centraal beheersorgaan. Een dergelijk centraal beheersorgaan zou het recht moeten krijgen op de naam 'RUBS' en het recht op de exploitatie van de gegevens. Daarnaast zal het moeten fungeren als registratiehouder ten behoeve van de Wet op de Persoonsregistratie, voor zover adressenbestanden worden aangelegd ten behoeve van een longitudinaal 'follow-up' onderzoek. Tevens dient het Centraal Beheersorgaan een aanspreekpunt te zijn voor verzoeken voor het geven van aanvullende vragen in de landelijke enquête van een bepald schooltype. Door het brede scala aan activiteiten dat moet worden verricht, ligt het voor de hand dat de centrale beheersinstantie diverse taken geheel of gedeeltelijk uitbesteedt aan derden. 
Schema IV. Overzicht van de afbakening van activiteiten tussen de schooladministraties, de reglonale organlsatles en de landelijke organisatie

Uitroerenden

Scholen

Regionale organisatles

Landel ljke organtsatie

\section{Activiteiten}

- aanieveren adressen van schoolverlaters naar gevolgde vakrichting en geslacht;

- ondertekening aanschrijfbrief;

- aanleveren telefoonnummers schoolverlaters ten behoeve van non-respons onderzoek.

- onderhouden contacten met scholen ten behoeve van de opbouw van een adressenbestand van schoolverlaters;

- verzenden vragenlijsten en schriftelijke rappellering:

- non-respons onderzoek;

- informatieverstrekking aan scholen en bespreking RUBS-uitkomsten met het schoolmanagement;

- informatieverstrekking aan andere doelgroepen binnen de regio;

- produktontwikkeling mede op basis van het opnemen van aanvullende vragen in de (regionale) RUBS-enquète.

- vaststellen samenstelling panel en Jaarlijkse steekproeftrekking;

- vaststellen inhoud landelijke vragenlijst;

- het drukken van de vragenilijsten;

- coördinatle ultvoering enquête;

- algehele kwallteitsbewaking;

- contractuele aspecten ten aanzien van regionale ultwoering en participatie scholen;

- scholing en advisering ten behoeve van reglonale ultwoering;

- ontwikkelen en vaststellen classificatfesystemen;

- data-invoer en -bewerking;

- verwerken non-respons onderzoek;

- eventueel herwegen uitkomsten bij disproportionele stratificatle steekproef en op basis van ultkomsten van non-respons analyse;

- ontwikkelen databases en databeheer;

- opleveren standaardtabellen ten behoeve van school - en regionale rapportage;

- landelifke rapportages en voorlichting;

- produktontwikkeling;

- projectevaluatie. 
Het Ministerie van Onderwijs en Wetenschappen en net Ministerie van Sociale Zaken en Werkgelegenheid en/of het Centraal Bestuur van de Arbeidsvoorziening (CBA) zullen het initiatief moeten nemen ten aanzien van de organisatorische inkadering van het voorgestelde centrale beheersorgaan, waar de bestuurlijke verantwoordelijkheid zou moeten komen te liggen voor het RUBS-project. Uit gesprekken met participanten in het pilotproject is een tweetal suggesties op dit punt naar voren gekomen.

Vanuit de COA's is de suggestie gedaan een landelijke koepel van RDC's zorg te laten dragen voor de landelijke coördinatie van het RUBS-project. Vanuft deze koepelorganisatie zouden dan, al of niet via uitbesteding aan derden, de activiteiten kunnen worden uitgevoerd die op central niveau moeten plaatsvinden. Essentieel voor het adequat functioneren van een dergelijke organisatie is dat er geen sprake mag zijn van een regionale autonomie ten aanzien van de opzet en uitvoering van de RUBS-enquête. Bovendien is het zowel voor het uitbesteden van opdrachten aan derden als met betrekking tot de Wet op de Persoonsregistratie van belang dat het centrale beheersorgaan een juridische rechtspersoon is. Een nadeel van de bovengenoemde organisatievorm zou dan ook kunnen zijn dat de besluitvorming een omslachtig proces wordt.

Een andere optie voor de institutionalisering van het landelijke beheer van het RUBS-project is ons inziens het onderbrengen van de beheersfunctie bij het Landelijk Dienstverlenende Centrum i.o. (LDC). Een dergelijke inkadering vergemakkelijkt bovendien de afstemming op het informatiesysteem voor beroepsen opleidingskeuze I-See!. Door het LDC wordt echter een tweetal mogelijke bezwaren tegen een dergelijke opzet naar voren gebracht.

- De taakstelling van het LDC beperkt zich tot de studie- en beroepskeuzevoorlichting. Dit makt het onderbrengen van het landelijke beheer van RUBS bij het LDC onevenwichtig vanuit de optiek van de andere gebruiksdoelen van RUBS.

- Wanneer de uitvoering van het RUBS-project op regionaal niveau wordt verzorgd door de RDC's, creëert het onderbrengen van het landelijke beheer bij het LDC een hiërarchisering van de relatie tussen LDC en RDC's. Dit staat haaks op de meer klantgerichte relatie tussen de RDC's en het LDC, die door het LDC wordt nagestreefd.

Wat het LDC aantrekkelijk makt als centrale beheersinstantie is het feit dat zowel het Ministerie van Onderwijs en Wetenschappen als het Centraal Bestuur van de Arbeidsvoorziening (CBA) hierin participeren. Bovendien zou 
een eventuele verbreding van de taakstelling van het LDC deze beter doen aansluiten bij die van de RDC's, die bij de informatieverstrekking immers een ruimere taakstelling krijgen dan alleen de studie- en beroepskeuzevoorlichting.

Het 1 ijkt ons niet terecht op deze plaats verder in te gaan op de concrete keuze van de instantie van waruit het centrale beheer van het RUBS-project formeel dan wel feitelijk zou kunnen plaatsvinden. Om de bovengenoemde onderzoektechnische en -organisatorische redenen bepleiten wij in ieder geval de totstandkoming van een organisatorisch kader warin de taakstelling ten aanzien van de opzet en de uitvoering van het RUBS-project door een landelijk beheersorgaan wordt vastgesteld en de regionale uitvoering conform deze taakstelling plaatsvindt.

\subsubsection{Onderzoekkosten en mogel jjke financieringsbronnen}

Om een indruk te krijgen van de kosten die gepaard gaan met de uitvoering van het RUBS-project conform beide in paragraaf 4.3.2. naar voren geschoven onderzoekopzetten zal hieronder een globale begroting van de uitvoeringskosten worden gegeven11. Daarbij zal eerst een schatting worden gemaakt van de kosten uitgaande van een roterend panel onder scholen en vervolgens van de meerkosten van een integrale enquêtering. Bij de kostenbegroting voor het roterende panel onder scholen wordt uitgegaan van een jaarlijkse enquêtering met een totale steekproefomvang van circa 200.000 schoolverlaters, met een respons van circa $65 \%$. In onderstaande begroting wordt een onderscheid gemaakt tussen de kosten op centraal niveau en de kosten op regionaal niveau. Ter vergelijking wordt een indicatie gegeven van de additionele kosten bij een integrale enquêtering.

Op een aantal punten zal de in tabe 16 weergegeven begroting worden toege 1 icht. Deze begroting van de jaarlijkse kosten van het RUBS-project is slechts als indicatie bedoeld. Bij de begrote kosten van een landelijk projectleider is uitgegaan van een aanstelling in schaal 11 BBRA. De kostenposten, administratieve ondersteuning en de bureaukosten betreffen een globale schatting. De begrote drukkosten van de vragenlijsten en antwoordenveloppen, de kosten van de data-invoer en codering en de kosten van het opleveren van de

11. Daarbij worden alleen de kosten van een eerste-bestemingsenquête begroot. 
standaardtabellen zijn gebaseerd op de in de pilotstudie hiervoor gemaakte kosten. Daarentegen vormt de kostenpost voor de wetenschappel ijke ondersteuning van het project slechts een globale schatting van de hiervoor te maken kosten op basis van de bij deze kostenpost opgesomde activiteiten.

In de begroting is uitgegaan van het opleveren van circa 40 regionale standaardrapportages per opleidingstype. Uitgangspunt daarbij was vooralsnog de gebiedsindeling van de huidige 13 COA'S. Voor elk van deze regio's zou een drietal rapporten moeten worden opgeleverd (een AVO-, LBO- en MBO-rapport), waarbij telkens verbijzonderd wordt naar de onderliggende RBA-regio's. Wanneer er voor elke RBA afzonderlijk regionale standaardrapportages moeten worden opgeleverd, zullen er in totaal ruim $80(28 \times 3)$ standaardrapportages moeten worden samengesteld. Dit zal tot hogere kosten leiden dan hierboven begroot. Op landelijk niveau zijn 16 standaardrapportages begroot. Daarbij is uitgegaan van een standaardrapportage voor de volgende schooltypen: ITO/LTO, IHNO/LHNO, ILO/LAO, LNO, LEAO, KMBO/KMAO, MTO, MLO, MNO, MAO, MMO, MEAO, MDGO, MAVO, HAVO, VWO.

De kostenpost 'ontwikkeling en beheer nationale databestanden' heeft betrekking op de ontwikkeling en het beheer van het totale databestand. Het betreft hier activiteiten die uiteenlopen van datacleaning, het koppelen van de gegevens van verschillende jaren, het aanleveren van databestanden aan de regionale betrokkenen binnen en eventueel buiten het RUBS-project, het aanleveren van data ten behoeve van geautomatiseerde informatieprodukten, e.d. Het betreft hier slechts een globale schatting van de te maken kosten. Dit laatste geldt ook voor de begrote kosten voor produktontwikkeling e.d. Daarbij moet uitdrukkelijk worden gesteld dat het begrote bedrag alleen betrekking heeft op de ontwikkelingsactiviteiten en niet op de daadwerkelijke exploitatie van eventuele nieuwe informatieprodukten. Ook de kosten van informatieprodukten als I-Seel of het ROA-informatiesysteem onderwijsarbejdsmarkt, waraan de RUBS-gegevens kunnen worden aangeleverd, blijuen vanzelfsprekend buiten beschouwing. 
Tabe1 6. Begrote onderzoekkosten roterend panel

\section{Kosten op centraal niveau}

landelijk projectleider

administratieve ondersteuning

bureaukosten

drukkosten vragenlijsten, enveloppen e.d.

data-invoer en codering

opleveren 15.000 standaardtabel len e.d. voor school- en regionale rapportages

wetenschappelijke ondersteuning, steekproeftrekking, non-responsanalyse, ontwikkelen meetinstrument, classificatiesystemen, vaststellen noodzakelijke weglingscoëfficiënten, evaluatie-uitkomsten e.d.

reglonale standaardrapportages per opleldingstype (AVO, LBO, MBO) (circa 40)

landellyke standaardrapportages (16)

ontwikkeling en beheer nationale

databestanden

produktontwikkeling e.a. activiteiten

in ontwikkelfase

Total

\section{Kosten regionale uftvoering}

regionale projectmedewerkers (10fte)

administratieve ondersteuning (10fte)

bureaukosten

verzendkosten e.d.

totaal

Totaal generaal f $90.000,--$

f $50.000,--$

f $70.000,--$

f $40.000,--$

f $250.000,--$

f $150.000,--$

f $600.000, \ldots$

f $200.000,--$

f $100.000,--$

f $150.000,--$

f $1.950 .000,--$

f $600.000, \ldots$

f $400.000,--$

f $550.000,--$

f $500.000,--$ f $500.000,-$

f $2.050 .000,--$ f $4.000 .000,-0$ f $4.000 .000,--$ $=x=x=\pi=x=\pi=x=\pi$ 
Bij de berekening van de personeelskosten op regionaal niveau is er van uitgegaan dat 1 full-time projectmedewerker met 1 full-time administratieve kracht in staat zijn de dataverzameling met betrekking tot circa 20.000 schoolverlaters te verzorgen en daarnaast zorg te dragen voor informatieverstrekking aan de participerende scholen en andere nationale en regionale belangstellenden. In het pilotproject lag het aantal benaderde schoolverlaters per full-time projectmedewerker, met administratieve ondersteuning, overigens aanzienlijk lager. Daar de taakstelling op regionaal niveau bij de door ons voorgestelde organisatiestructuur echter geringer is dan bij het pilotproject, lijkt het reëel dat per projectmedewerker meer schoolverlaters kunnen worden benaderd. Wel mag worden verwacht dat er op dit punt de eerste jaren waarschijnlijk sprake zal zijn van aanloopkosten bij de regionale uitvoering van het project.

Tabel 7. Additionele kosten integrale enquêtering

\section{Additionele kosten op centraal niveau}

bureaukosten e.d.

vragenlifsten, enveloppen e.d.

data-1nvoer en codering

opleveren 15.000 standaardtabellen e.d.

ten behoeve van schoolrapportages

Additionele kosten regionale uitvoering

projectmedewerkers (10 fte)

administratieve ondersteuning (10 fte)

bureaukosten

verzendkosten e.d. f $60.000, \ldots$

f $40.000, \ldots$

f $250.000,--$

f $150.000, \ldots$ f $600.000,-=$

f $400.000,--$

f $500.000, \ldots$

f $500.000,--$

f $2.500 .000, \ldots$ 
De begrote bureaukosten zijn gebaseerd op een globale schatting. Voor de kostenpost verzendkosten e.d. is een bedrag van $f 2,50$ per schoolveriater opgenomen. Hiervan moeten maximaal drie verzendingen worden verricht (1e verzending, rappellering en respons). Overigens moet het mogelijk zijn om met PTT-Partijenpost tot scherpere prijsafspraken te komen.

Tabel 7. geeft een overzicht van de additionele kosten die een integrale enquêtering van de totale schoolverlaterspopulatie met zich mee zou brengen. De diverse kostenposten zijn daarbij op dezelfde wijze vastgesteld als bij de begroting van de onderzoekkosten van een roterend panel onder scholen. Tegenover de hier begrote extra kosten van circa $f$ 2.500.000,-- zal slechts een geringe besparing staan als gevolg van het verdwijnen van de noodzaak tot het jaarlijks trekken van een steekproef onder de scholen.

Tabel 8. geeft tenslatte enkele kengetallen met betrekking tot de begrote kosten per te enquêteren schoolverlater.

Tabel 8. Kosten per te enquêteren schoolverlater: enkele kengetall len

kostenpost. kosten per te enquêteren schoolverlater

Personeel siasten op regionaal niveau

Kosten vragenifjst, enveloppen e.d.

Verzendkosten

Data-invoer en codering

Totale kosten bij roterend panel (ca. 200.000 schoolverlaters)

Totale kosten per extra te enquêteren schoolverlater
f $5,--^{\star}$
f 0,25
f 2,50
$f 1,25$

f $20,--$

f 12,50

* Deze kosten zijn slechts varlabel bij een toe- of afname van circa 20.000 schoolverlaters.

Ten aanzien van de financiering van de hierboven begrote kosten van beide onderzoekvarianten is het van belang op te merken dat het hier in feite gaat om de begrote 'bruto' kosten. Hier staan enkele mogelijke 'besparingen' tegenover. Zo moet worden bedacht dat een landelijke uniforme RUBS-enquête voor een deel de plaats kan innemen van verschillende ad hoc onderzoeken 
onder schoolverlaters met een soortgelijke vraagstelling op zowel landelijk als regional en lokaal niveau. Bovendien zullen de beoogde regionale en landelijke rapportages mogelijk in de plaats kumnen komen van bestaande informatieprodukten. Onduidelijk is voor ons in hoeverre de activiteiten van met name de RDC's ten behoeve van het RUBS-project gezien kunnen worden als een concrete invulling van de eigen reguliere werkzaamheden.

Voor de financiering van het RUBS-project impliceert het loslaten van de regionale autonomie ten aanzien van de opzet van de RUBS-enquête binnen de eigen regio dat, ook niet zoals bij het pilotproject nog het geval was, op regionaal niveau financieringsbronnen moeten worden aangeboord. Weliswaar blijft dit een reële optie wanneer het gaat om het stellen van aanvullende enquêtevragen of om het ontwikkelen van nieuwe produkten voor specifieke gebruikersgroepen in de eigen regio. Echter voor de uitvoering van de 'reguliere' activiteiten dient de financiering op landelijk niveau plaats te vinden c.q. gecoördineerd te worden. Een dergelijke opzet maakt het mogelijk dat de bekostiging van de regionale activiteiten in aansluiting op de regionale taakstelling plaatsvindt vanuit het centrale beheersorgaan.

Voorzover RUBS informatie oplevert voor het schoolmanagement mag van het Ministerie van Onderwijs en Wetenschappen een belangrijke bijdrage in de financiering van het project worden verwacht. Daarnaast is het Ministerle van Onderwijs en Wetenschappen ook belanghebbende bij de informatie die het RUBS-project oplevert voor het onderwijsbeleid en de studie- en beroepskeuze. Het betreft hier met name de monitoring van de aansluiting tussen onderwijs en arbeidsmarkt. In feite kan RUBS daarbij fungeren als een instrument ter bewaking van de 'externe' kwaliteit van het onderwijs.

Ook het Ministerie van Sociale Zaken en Werkgelegenheid en/of het toekomstige CBA hebben belang bij een adequate studie- en beroepskeuzevoorlichting. In het kader van een preventief beleid ten aanzien van de aansluitingsproblematiek op de arbeidsmarkt is ook het laatstgenoemde ministerie gebaat bij een informatie-instrument voor het schoolmanagement. Daarnaast kan RUBS, zoals eerder werd opgemerkt, ook een signalerende rol spelen naar het arbeidsvoorzieningsbeleid c.q. het scholingsbeleid.

Hiermee zijn, vanuit de mogelijke gebruiksdoelen van RUBS en de gewenste centrale aanpak, de meest voor de hand liggende financieringsbronnen van het RUBS-project genoemd. Ten aanzien van de toekomstige organisatiestructuur 
van de arbeidsvoorziening doet zich hierbij het probleem voor dat op regionaal niveau wordt beslist over de besteding van een belangrijk deel van de beschikbare middelen. Vanwege de hierboven uiteengezette noodzaak om de taakstelling van het RUBS-project op centraal niveau vast te leggen en de uitvoering hiervan ook op centraal niveau te garanderen, is het noodzakelijk een eventuele financiering door de RBA's op landelijk niveau te coördineren.

Vanzelfsprekend komen ook het bedrijfsleven en de overheden in hun rol als werkgever in aanmerking voor het medefinancieren van het project. Het meest reëel lijkt hier een marktgerichte aanpak, waarbij de aangeboden informatieprodukten echter worden verkocht tegen een prijs die hoger ligt dan de marginale kosten van deze produkten. Dit zou echter het publiceren van de regionale standaardrapportages kunnen doorkruisen. Ook de genoemde maatwerkrapportages en met name de projecties van de toekomstige uitstroom uit het onderwijs naar de arbeidsmarkt komen voor een dergelijke 'produktfinanciering' in aanmerking.

Bij diverse gemeentelijke en provinciale overheden blijkt eveneens een grote belangstelling te bestaan voor de uitkomsten van regionale schoolverlatersenquêtes. Ook voor deze doelgroepen zou primair gedacht moeten worden aan vormen van produktfinanciering.

Vooralsnog ontbreekt het inzicht in de mogelijke opbrengsten van het RUBSproject vanuit de laatstgenoemde financieringsbronnen. Overwogen zou kunnen worden door middel van een marktonderzoek hiervan een indicatie te krijgen. Een mogelijke complicatie hierbij is waarschijnlijk dat zogenaamd 'free-rider' gedrag, vanwege de brede toegankelijkheid van de regionale standaardrapportages, de uiteindelijke opbrengsten van een dergelijke produktfinanciering in ongunstige zin zal beinvloeden. Derhalve moet worden geconcludeerd dat het in ieder geval raadzaam is het RUBS-project voor het overgrote deel te financieren vanuit de Ministeries van Onderwijs en Wetenschappen en Sociale Zaken en Werkgelegenheid en het CBA en/of de RBA's. Zoals hierboven reeds werd opgemerkt, is het voor ons onduidelijk in hoeverre de activiteiten van met name de RDC's ten behoeve van het RUBS-project gezien kunnen worden als een concrete invulling van de eigen reguliere werkzaamheden. Wanneer dit het geval is, zou dit in de besluitvorming ten aanzien van de financiering van het RUBS moeten worden betrokken. Daarbij moet er overigens uitdrukkelijk voor worden gewakt dat een decentralisatie van de financiering niet leidt tot het uithollen van de taakstelling van het centrale beheersorgaan. 
Temeer daar de RUBS-gegevens voor een groot deel het karakter hebben van een zogenaamd 'collectief goed', is het moeilijk de kosten te verbijzonderen naar de verschillende gebruiks- c.q. beleidsdoeleinden waarvoor de RUBS-data van belang kunnen zijn. Wel kan worden opgemerkt dat enkele van de vragen in de huidige vragenlijst met name van belang zijn voor het arbeidsvoorzieningsbeleid. Daar staat tegenover dat de additionele kosten van een integrale enquêtering ten opzichte van de kosten van een roterend panel onder scholen met name gemaakt moeten worden om jaarlijks voor iedere school over informatie te kunnen beschikken over de bestemming van de schoolverlaters, hetgeen met name van belang is voor het schoolmanagement en het onderwijsbeleid.

\subsection{De verdere ontwikkeling van RUBS}

Wanneer een positieve besluitvorming over voortzetting van het RUBS-project medio 1990 zou plaatsvinden, is het technisch gezien mogelijk om april 1991 op basis van de nieuwe opzet een enquête te houden onder de schoolverlaters van het schooljaar 1989/1990. Dit heeft als voordeel dat de continuiteit van het RUBS-project niet wordt doorbroken. Deze continüiteit is met name van belang om te voorkomen dat de in de diverse regio's opgebouwde expertise ten aanzien van de uitvoering van het onderzoek niet verloren gaat. Beide opdrachtgevers van het RUBS- pilotproject zouden het voortouw moeten nemen bij de besluitvorming ten aanzien van de te volgen onderzoekvariant, de gewenste organisatiestructuur en de (voorlopige) financiering van het project.

Wanneer gekozen wordt voor een steekproef onder schoolverlaters of voor een roterend panel van scholen dient reeds op korte termijn te worden gestart met het trekken van een dergelijke steekproef en met het in kaart brengen van de eventuele complicaties (noodzaak van oververtegenwoordiging van bepalde schooltypen e.d.) die daarbij kunnen optreden. Bovendien zullen reeds voor het einde van het kalenderjaar de activiteiten op centraal en regionaal niveau moeten worden opgestart. Indien een definitieve besluitvorming ten aanzien van de organisatie- en financieringsstructuur niet voor medio 1990 kan plaatsvinden, maar er in principe toch tot een voortzetting van het RUBSproject wordt besloten, is het van groot belang de voor de diverse betrokkenen noodzakelijke continuiteit te garanderen door het opzetten van een interimproject. 


\section{LITERATUUR}

COA Noord-Holland (1989), Nieuwsbrief nr. 10, Amsterdam.

Dam, J.W. van, A. de Grip en J.A.M. Heijke (1988), Op zoek naar informatiebronnen over de arbeidsmarktpositie van academici, ROA-W-1988/3, Maastricht.

Dam, J.W. van, A. de Grip en J.A.M. Heijke (1990) Huidig follow-up onderzoek levert dikwijls beperkte resultaten, in: Universiteit en Hogeschool, jaargang 36 , nummer 4 .

Dam, J.W. van, J.A.M. Heijke en G.W.M. Ramaekers (1989), Ontwerp van een arbeidsmarktscanner voor academici, ROA-R-1989/3, Maastricht.

Dam, J.W. van en M. Mortier (1990), Inventarisatie van arbeidsmarktonderzoeken onder afgestudeerden van het HBO, ROA-W-1990/1, Maastricht.

Grip, A. de, J.A.M. Heijke en R.J.P. Dekker (1989), De arbeidsmarkt naar opleiding en beroep in 1992, ROA-R-1989/8, Maastricht.

HBO-Raad (1989), Uitvoeringsplan sectorale kwaliteitszorg, Den Haag.

Hermans, B.M.J.(red.)(1985), Kiezen van de baan. Opleidingskeuze en arbeidsmarktperspectief. Verslag van een studieconferentie van het LCAS, 21 november 1985.

Laarhoven, P. van (1990), Een onderzoeksontwerp voor het RUBS-project, RION, Groningen.

Laarhoven, P. van en S. Waslander (1990), Uitstroom en besteming van MDGOschoolverlaters. Een landelijke rapportage over het RUBS-project, RION, Groningen.

LCAS, (1988), Registratie van de Uitstroom en Besterming van Schoolverlaters, een samenwerkingsproject $\angle C A S / C O A ' s$, projectvoorstel, 's-Gravenhage.

LCAS, CORO (1990), Registratieproject Uitstroombesteming Schoolverlaters, Eindrapport, CORO/LCAS.

LPC (1989), Marktgericht Beroepsonderwijs, methodiek voor de versterking van het $\angle B O$, dee 1 I Informatie, Den Bosch.

Meesters, M. en J. Huson (1990) Eindrapportage schoolloopbanen en arbeidsmarktpositie, OSA-W68, 's-Graverihage.

ROA (1989), Naar een informatiesysteem onderwijs-arbeidsmarkt, Onderzoekprograma 1989/1990, Maastricht.

SER (1990), Advies Rendement Onderwijs, 's-Gravenhage.

SMO (1989), Het Nederlandse onderwijs als wapen in de internationale concurrentiestrijd, $\mathrm{s}^{\mathrm{H}}$-Gravenhage.

VOI (1989), De Wet Persoonsregistratie, In: VOI-Nieuws nr. 3.

VOI (1989), VOI-code voor de WPR, conceptgedragscode. 
VSNU (1988), Gids voor de externe kwaliteitszorg, Utrecht.

Waslander, S. en P. van Laarhoven (1990), Uitstroom en Besteming van MDGOschoolverlaters in de drie noordelijke provincies, Een regionale rapportage over het RUBS-project in 1989, Groningen.

Zaanstreek-Waterland (1989), Onderwijskundige bedrijfsvoering: Beleid en instrumenten, Zaanstad. 
NAAM

drs. J. van Dam

drs. W. van Gorsel

dr. A. de Grip (voorzitter)

drs. D. Hermans

drs. R. Holm

drs. G.J. Huybens

R. Ingenhousz

drs. K. Kegelaar

drs. P. van Laarhoven

drs. M. van Linge

drs. J. Neve

N. van Noppen

H. Rutjes

G. Schalkoort

drs. K. van der Veen

drs. P. van Voorthuysen

S. Waslander

drs. R. van de Winkel

\section{INSTELLING}

ROA

Provinciaal Opbouw Orgaan Zeeland

ROA

LCAS

COA Friesland

COA Noord-Holland

COA Overijssel

COA Groningen

RION

CORO

COA Zeeland

COA Zuid-Holland Noord

COA Rijndelta

COA Drenthe

COA Flevoland

COA Gelderland

RION

COA Utrecht 
NAAM

drs. J.A. van den Bandt-Stel

drs. P.C. van den Dool

drs. J. Fokkema

drs. B. Kamps

drs. S.A. van der Schoot

prof. dr. M. de Smidt (voorzitter)

dr. B. de Vries

\section{INSTELLING}

Raad van de Centrale Ondernemingsorganisaties ( $R C O)$

Ministerie van Onderwijs en Wetenschappen

Ministerie van Sociale Zaken en Werkgelegenheid

Raad voor de Beroepskeuzevoorlichting

Nederlandse Vereniging van

Schooldekanen

Rijksuniversiteit Utrecht

Instituut voor Toegepaste Sociologie 


\section{Vragenlijst voor schoolverlaters \\ MBO, KMBO, HAVO/VWO en HBO 1987/88}

\section{Enkele algemene gegevens}

1. Wanneer ben je geboren?

2. Geslacht:

3. Welke taal spreek je thuis meestal met je ouders/verzorgers?

\section{jaar: 19 \\ maand:}

man

vrouw

Nederlands (ook streektaal of dialect)

Surinaams of Antilliaans

Turks of Marokkaans

Westeuropese taal (b.v. Frans, Duits)

Zuideuropese taal (b.v. Spaans, Grieks)

andere taal:
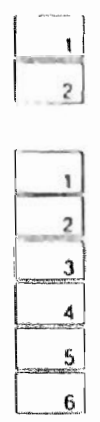

4. Woonplaats:

De opleiding in het schooljaar 1987/88 (vorig jaar)

5 a. Heb je van deze opleiding vorig jaar het diploma behaald?

\begin{tabular}{rr} 
nee \\
ja \\
alleen deelcertificaten \\
alleen theorie-examen \\
\hline 2 \\
\hline 3
\end{tabular}

b. In welke klas/studiejaar ben je vorig jaar van school gegaan?

klas:

c. Wat is het laatste onderwijsdiploma dat je gehaald

hebt vóór de opleiding van vorig jaar?

(bijvoorbeeld LTS-bouw, MAVO, HAVO, MDGO-AW)

Huidige bezigheden

6. Volg je op dit moment een opleiding in het leerlingwezen (streekschool e.d.)

of een in-service opleiding in de verpleging of verzorging?

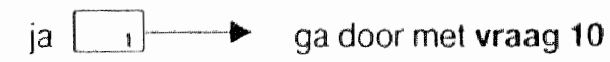

nee

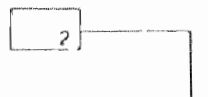

ga door met vraag 7

7. Wat is op dit moment je voornaamste bezıgheid?

- full-time dagoplerding (meer dan 3 dagen per week)

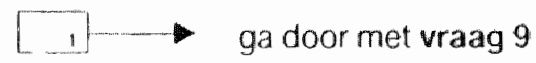

betaalde baan

$\left[\begin{array}{l}2 \\ -\end{array}\right]$ ga door met vraag 11

- werkloos

- hushouden.

- militarre dienstplicht

- anders namelijk: 
8 a. Heb je een betaalde baan gehad sinds je van school bent?

maanden:

b. Zo ja, hoeveel maanden heb je in totaal gewerkt?

Ga door met vraag 16

De opleiding die je nu volgt

Voor degenen die een full-time dagopleiding volgen:

9 a. Welke opleiding volg je op dit moment? (bijvoorbeeld: HAVO, KMBO, MTS, HTS, HBO-J)

b. Welke vakrichting, afdeling of specialisatie doe je bınnen deze opleiding? (bijvoorbeeld: Bouwkunde, Bestuurskunde, Jeugdwelzijnswerk)

Ga door met vraag 16

Voor degenen die een opleiding in het leerlingwezen (streekschool e.d.) of een in-service opleiding volgen:

10 a. Wat voor opleiding volg je op dit moment?

(bijvoorbeeld: automonteur, installatietechniek, ziekenverzorgende, A-verpleegkundige)

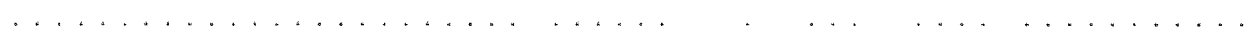

b. Naam leerlingstelsel:

(ECABO, VAM, SOM (metaal), VEV (electro), OVDB, Kappers, Horeca en dergelijke)

c. Heb je naast deze opleiding een

betaalde baan?

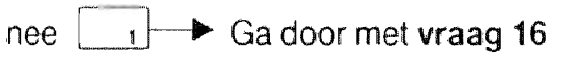

ja

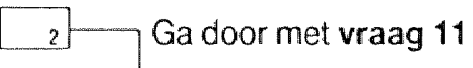

Je huidige werk en beroep

11 a. Werk je in loondienst?

nee

ia

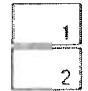

b. Wat voor aanstelling heb je?

vaste aanstelling tıdelike aanstelling werk voor uitzendbureau

c. Hoeveel uur per week werk je meestal?

minder dan 20 uur

20 tot 32 uur

meer dan 32 uur
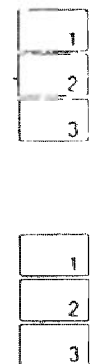
12 a. Hoe ben je aan dit werk gekomen? (één antwoord aankruisen)

via het Arbeidsbureau

via familie of kennissen

via een advertentie in de krant via een advertentie in een winkel e.d.

via een uitzendbureau

via vakantiewerk/bijbaantje

door de stage/via de school

zelf aan de werkgever om werk gevraagd

voor mijzelf begonnen

anders:

b. Hoe snel heb je werk gevonden

meteen

toen je vorig jaar van school ging?

na 1 - 3 maanden

na 4 - 6 maanden

na meer dan 6 maanden

13 a. Hoe heet het beroep of de functie die je uitoefent?

(bijvoorbeeld: secretaresse, tuinder, groepsleider, bouwkundig tekenaar, verkoopster)

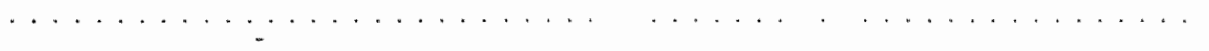

b. Wat zijn je voornaamste werkzaamheden?

(bijvoorbeeld: technisch tekenen, veeverzorging, typen, boekhouden)

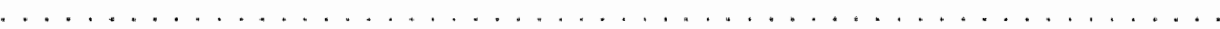

c. Op wat voor afdeling werk je?

(bijvoorbeeld: administratie, montagehal, magazijn, receptie, operatiekamer)

................... .

$\ldots \ldots \ldots \ldots$

d. Geef je leiding aan ander personeel?
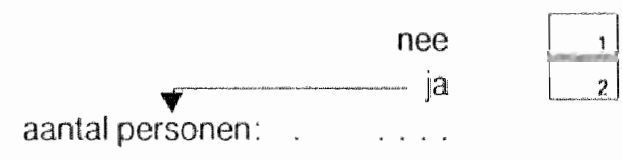

$14 \mathrm{a}$. Bij wat voor bedrijf of instelling werk je?

(bijvoorbeeld: machinefabriek, constructiewerkplaats, kledingwinkel, ziekenhuss)

b. Hoeveel mensen werken er ongeveer bij hel bedrijf?

minder dan 10

10 tot 50

50 tot 100

meer dan 100

weet ik nict

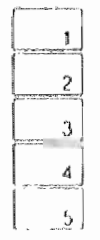

c. In welke plaats werk je?

15. Hoeveel verdien je ongeveer netto ('schoon') per maand?

gulden

zegik llever net

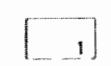


16 a. Heb je de afgelopen 4 weken naar (ander) werk gezocht?

b. Zo ja, hoe heb je de afgelopen 4 weken naar werk gezocht?

(LET OP: meer antwoorden mogelijk)

via het Arbeidsbureau via familie of kennissen

via advertenties in de krant via advertenties in winkels e.d.

via een uitzendbureau

via de stage/school zelf aan een werkgever om werk gevraagd anders

c. Sta je ingeschreven bij het Arbeidsbureau?

nee

17 a. Volg je een (nog een andere) cursus, training of part-time opleiding?
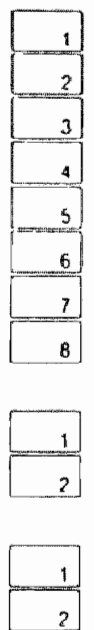

b Welke?

\section{De opleiding achteraf bezien}

18. Hieronder noemen we een aantal zaken. Geef aan of daar in de opleiding van vorig jaar (1987/88 dus) voldoende aandacht aan is besteed. Ga daarbij uit van wat je nu doet:

$\begin{array}{cccc}\text { te } & \text { vol- } & \text { te } & \text { niet van } \\ \text { veel } & \text { doende } & \text { weinig } & \text { toepassing }\end{array}$

a. Vakkennis/vaktheorie

b. Vreemde talen (Engels, Duits e.d.)

c. Een brief of een stuk schrijven

d. Met cijfers werken (wiskunde, rekenen)

e. Zelfstandig werken

f. Samenwerken met collega's

g. Met mensen omgaan

h. Praktijkoriëntatie of stage

i. Omgaan met apparatuur en materialen

1. Weten hoe een bedrijf georganiseerd is

k. Leiding geven

I. Organiseren/plannen

$\mathrm{m}$. Beroepskeuze/studiekeuze

n. Leren studeren

o. Kennis van arbeidsvoorwaarden

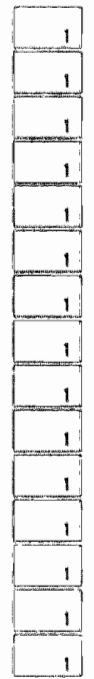
(CAO, ondernemingsraad, wat te doen bij ontslag e.d.)
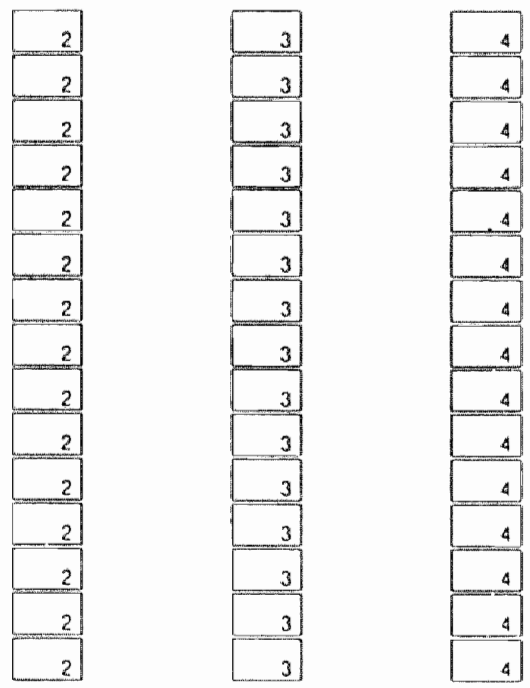

Ruimte voor opmerkingen

Bedankt voor het invullen

Stuur de vragenlijst zo snel mogelijk op in de antwoordenvelop (een postzegel is niet nodig) 


\section{UBS}

\section{Vragenlijst voor schoolverlaters LBO en MAVO 1987/88}

\section{Enkele algemene gegevens}

1. Wanneer ben je geboren?

maand:

jaar: 19

2. Geslacht:

3. Welke taal spreek je thuis meestal met je ouders/verzorgers?

Nederlands (ook streektaal of dialect)

Surinaams of Antilliaans

Turks of Marokkaans

Westeuropese taal (b.v. Frans, Duits)

Zuideuropese taal (b.v. Spaans, Grieks) andere taal:

\begin{tabular}{c|r|} 
man & 1 \\
vrouw & 2
\end{tabular}

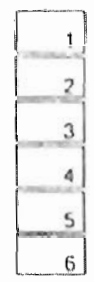

4. Woonplaats:

De opleiding in het schooljaar 1987/88 (vorig jaar)

5 a. Heb je van deze opleiding vorig jaar het diploma behaald?

nee

alleen deelcertificaten

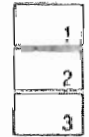

b. In welke klas ben je vorig jaar van school gegaan?

klas:

c. Heb je vorig jaar eindexamen gedaan?

nee

ja

aantal vakken op A-niveau:

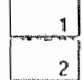

op B-niveau

op C-niveau:

op D-niveau:

d. Heb je al eens eerder dan vorig jaar

een diploma van LBO of MAVO gehaald?

nee

ja

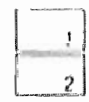

Huidige bezigheden

6. Volg je op dit moment een opleiding in het leerlingwezen (streekschool e.d.)

of een in-service opleiding in de verpleging of verzorging?

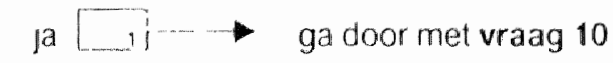

7. Wat is op dit moment je voornaamste bezigheid?

nee

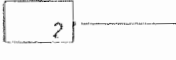
ga door met vraag 7

- $\quad$ full-time dagopleiding (meer dan 3 dagen per week)

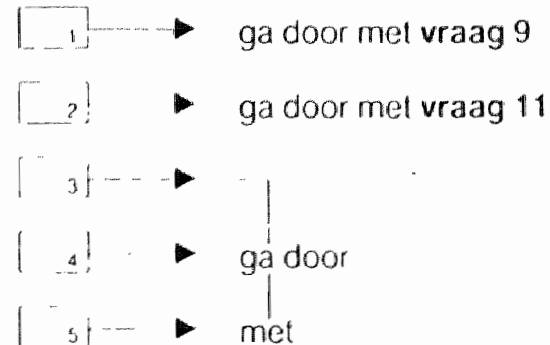

- militarre dienst

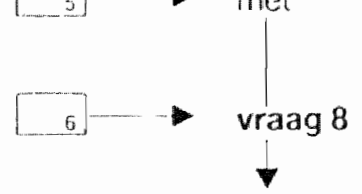


8 a. Heb je een betaalde baan gehad sinds je van school bent?

maanden:

b. Zo ja, hoeveel maanden heb je in totaal gewerkt?

Ga door met vraag 16

De opleiding die je nu volgt

Voor degenen die een full-time dagoplerding volgen:

9 a. Welke opleiding volg je op dit moment? (bijvoorbeeld: HAVO, KMBO, MTS, LTS, MEAO)

b. Welke vakrichting, afdelıng of specialisatie doe je binnen deze opleiding? (bijvoorbeeld: Bouwkunde, bestuurlijke richting)

Ga door met vraag 16

Voor degenen die een opleiding in het leerlingwezen (streekschool e.d.) of een in-service opleiding volgen:

10 a. Wat voor opleiding volg je op dit moment?

(bijvoorbeeld: automonteur, installatietechniek, ziekenverzorgende, A-verpleegkundige)

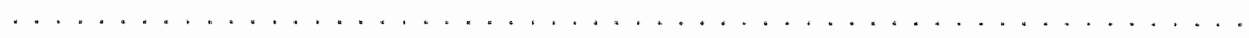

b. Naam leerlingstelsel:

(ECABO, VAM, SOM (metaal), VEV (electro), OVDB, Kappers, Horeca en dergelijke)

c. Heb je naast deze opleiding een betaalde baan?
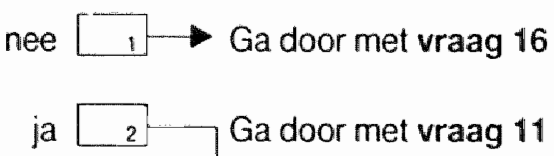

Je huidige werk en beroep

11 a. Werk je in loondienst?

nee

ja

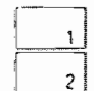

b. Wat voor aanstelling heb je?

vaste aanstelling tijdelijke aanstelling werk voor vitzendbureau

c. Hoeveel uur per week werk je meestal?

minder dan 20 uur

20 tot 32 uur meer dan 32 uur 
b. Hoe snel heb je werk gevonden toen je vorig jaar van school ging? meteen

na 1 - 3 maanden na 4 - 6 maanden na meer dan 6 maanden

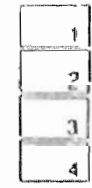

13 a. Hoe heet het beroep of de functie die je uitoefent?

(bijvoorbeeld: automonteur, tuinder, groepsleider, verkoopster)

b. Wat zijn je voornaamste werkzaamheden?

(bijvoorbeeld: verwarmingen installeren, veeverzorging, typen, boekhouden)

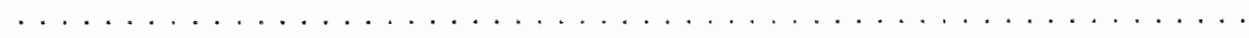

c. Op wat voor afdeling werk je?

(bijvoorbeeld: administratie, montagehal, magazijn, receptie, operatiekamer)

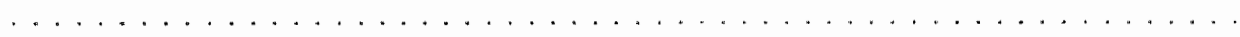

d. Geef je leiding aan ander personeel?

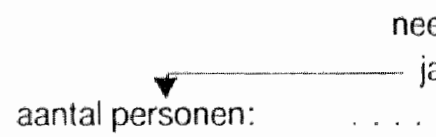

$14 \mathrm{a}$. Bij wat voor bedrijf of instelling werk je?

(bijvoorbeeld: machinefabriek, constructiewerkplaats, kledingwinkel, ziekenhuis)

b. Hoeveel mensen werken er ongeveer bij het bedrif?

minder dan 10

10 tol 50

50 tot 100

meer dan 100

weet ik niet

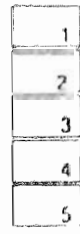

c. In welke plaats werk je?

15. Hoeveel verdien je ongeveer netto ('schoon') per maand?

gulden 
16 a. Heb je de afgelopen 4 weken naar (ander) werk gezocht?

b. Zo ja, hoe heb je de afgelopen 4 weken

via het Arbeidsbureau naar werk gezocht?

(LET OP: meer antwoorden mogelijk)

via familie of kennissen

via advertenties in de krant via advertenties in winkels e.d.

via een uitzendbureau via de stage/school zell aan een werkgever om werk gevraagd anders:

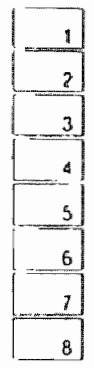

c. Sta je ingeschreven bij het Arbeidsbureau?

nee

17 a. Volg je een (nog een andere) cursus, training of part-tıme oplerding?

b. Welke?

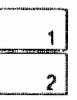

\section{De opleiding achteraf bezien}

18. Hieronder noemen we een aantal zaken. Geef aan of daar in de opleiding van vorig jaar (1987/88 dus) voldoende aandacht aan is besteed.

Ga daarbij uit van wat je nu doet:

$\begin{array}{cccc}\text { te } & \text { vol- } & \text { te } & \text { niet van } \\ \text { veel } & \text { doende } & \text { weinig } & \text { toepassing }\end{array}$

a. Vakkennis/vaktheorie

b. Vreemde talen (Engels, Duits e.d.)

c. Een brief of een stuk schrijven

d. Met cijfers werken (wiskunde, rekenen)

e Zelfstandig werken

f Samenwerken met collega's

g. Met mensen omgaan

h. Praktijkoriëntatie of stage

1. Omgaan met apparatuur en materialen

I Weten hoe een bedrijt georganiseerd is

$k$. Leiding geven

1 Organiseren/plannen

$m$ Beroepskeuze/studiekeuze

n. Leren studeren

o. Kennis van arbeidsvoorwaarden
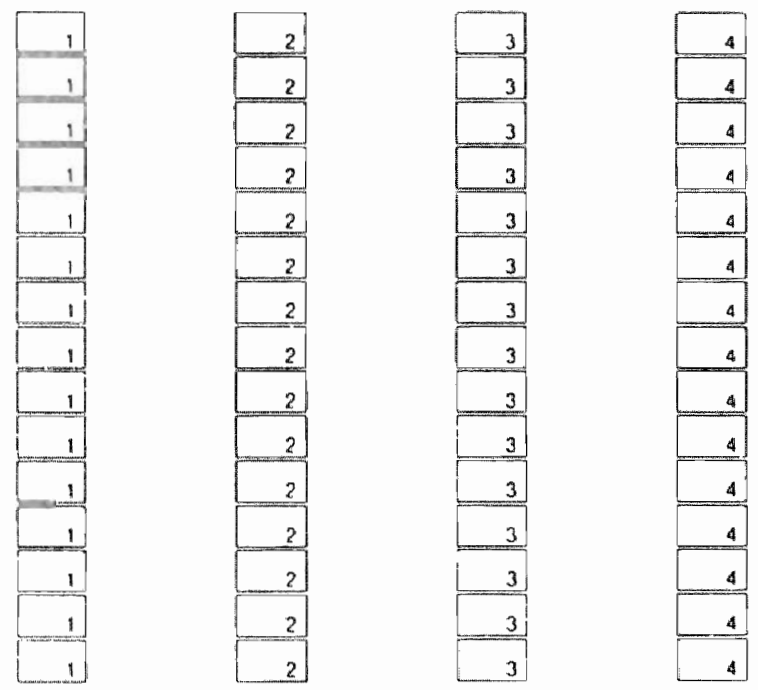

( $\mathrm{CAO}$, ondernemingsraad, wat te doen by ontslag e.d.)

Ruimte voor opmerkingen

Bedankt voor het invullen

Stuur de vragenlijst zo snel mogelijk op in de antwoordenvelop (een postzegel is niet nodig) 
De COA's zijn over het algemeen zeer te spreken over de vragenlijst. Niettemin is er door de COA's een aantal suggesties gedaan voor mogelijke wijzigingen:

- De term 'schoolverlaters' in het vervolg niet meer gebruiken. Veel leerlingen stappen $\mathrm{nl}$. over naar een andere afdeling of gaan een vervolgopleiding doen. Zij beschouwen zichzelf niet als schoolverlater en achten de vragenlijst niet op zichzelf van toepassing. Een aantal heeft om deze reden de lijst oningevuld naar de school teruggestuurd.

- De begeleidende brief niet beginnen met 'beste oud-leerling'. Dit wekt dezelfde verwarring ondat een deel van de schoolverlaters op dezelfde school een andere opleiding volgt.

- De vraag naar de etnische achtergrond (vraag 3) lijkt op het eerste gezicht minder goed te werken (zie ook paragraaf 2.4 ).

- De vraag naar eerder behaalde diploma's, respectievelijk vraag $5 d$ in de LBO/MAVO-versie en vraag $5 c$ in de MBO-versie, wordt vaak verkeerd begrepen. Men vult dan de opleiding van vorig jaar in.

- Sommige leerlingen vinden het vreemd dat er niet gevraagd wordt welke opleiding zij vorig jaar gedaan hebben (deze informatie $z i t$ in leerl ingnummer verwerkt).

- De vraag of men op dit moment een opleiding in het leerlingwezen volgt (vraag 6), wordt niet altijd goed begrepen: ook leerlingen die KMBO ed. volgen vullen nier soms 'ja' in. Dit is misschien moeilijk te vermijden.

- Het onderscheid tussen leerlingwezen en full-time opleidingen is voor sommige respondenten niet duidelijk. Dit leidt tot een verkeerde routing die achteraf bij de data-entry gecorrigeerd moet worden. Misschien dat vooraf meer informatie gegeven moet worden.

- In de vraag naar de huidige bezigheid (vraag 7) zou de keuzemogelijkheid 'werkloos' nader gespecificeerd moeten worden.

- Vraag 7 over de voornaamste bezigheid: een leerling die naast zijn of haar baan een cursus volgt of studeert, kan dit maar heel spaarzaam kwijt op het formulier, terwijl dit belangrijk is voor een school om te weten. ook een leerling die net zoveel tijd besteedt aan studie als aan werk komt in de probiemen.

- Vraag 11b de antwoordmogelijkheid 'anders, namelijk...' toevoegen.

- Vraag 14: vraag opnemen over wens/initiatief tot bijscholing/ nascholing op initiatief werkgever/respondent.

- Positie van vraag 17 is wat ongelukkig, maar is moeilijk anders te plaatsen. 
- Vraag 18 (de opleiding achteraf bezien) aanpassen: ruimte voor opmerkingen losmaken van vraag 18; De ruimte voor opmerkingen wordt verhoudingsgewijs het meest benut voor opmerkingen over de school; logisch gezien de vraag die er direct boven staat. Daardoor worden er minder opmerkingen gemaakt over andere zaken.

- In de regio bestaat bij somige scholen behoefte aan extra vragen over de eigen school (beoordeling) en bij de provincie aan meer vragen over het verloop van sollicitatiegesprekken en redenen warom men al of niet is aangenomen. Men wil zo beter zicht krijgen op de beoordeling van de schoolverlaters door de werkgevers.

- Wat vooral voor de verschillende scholen van belang is, is dat zij contact blijven houden met hun oud-leerlingen, zonder dat zij daar een extra mailing of telefonische inspanning voor moeten verrichten. Er zou overwogen kunnen worden om een extra vragenformulier van de school bij de RUBS-vragenlijst te voegen om in deze behoefte te voorzien.

- Het MDGO is vooral geinteresseerd in de kwalitatieve aspecten van de aansluiting. Het is nog niet duidelijk of de huidige vragenlijst daarin voldoende kan voorzien.

\section{Conclusie:}

De opzet en inhoud van de huidige vragenlijst voldoet (althans in de ogen van de direct bij het onderzoek betrokken partijen) in hoofdlijnen aan de gestelde doelstellingen. Alleen de vraag naar de etnische achtergrond lijkt minder goed te werken. Ook over de effectiviteit van het opnemen van de clausule met betrekking tot het waarborgen van de anonimiteit van de respondent bestaan twijfels. Verschillende vragen zouden qua doelstelling, formulering en positie heroverwogen moeten worden. Veel hangt echter af van de waarde die de diverse gebruikers toekennen aan de tabellen. 


\section{Tijdstip}

oktober 188

november ' 88

\section{Activiteit}

Meting uitstroom-

gegevens (tweede

deelproject)

Opstellen concept-

werkplan en samenwer-

kingsovereenkomst ROA-COA's

Verwerking uitstroomgegevens (tweede deelproject)

Opdrachtverlening aan

RION en LCAS; voorstel

samenwerkingsovereen-

komst met COA's

Eerste bijeenkomst projectteam; bespreking concept-werkplan, vergader-

schema e.d. (18 november)

Definitieve vaststelling werkplan

Acceptatie opdrachtverlening RION, LCAS

Acceptatie samenwerkingsovereenkomst. Hiermee wordt tevens het aantal participerende COA's vastgelegd

Samenstellen begeleidingscommissie

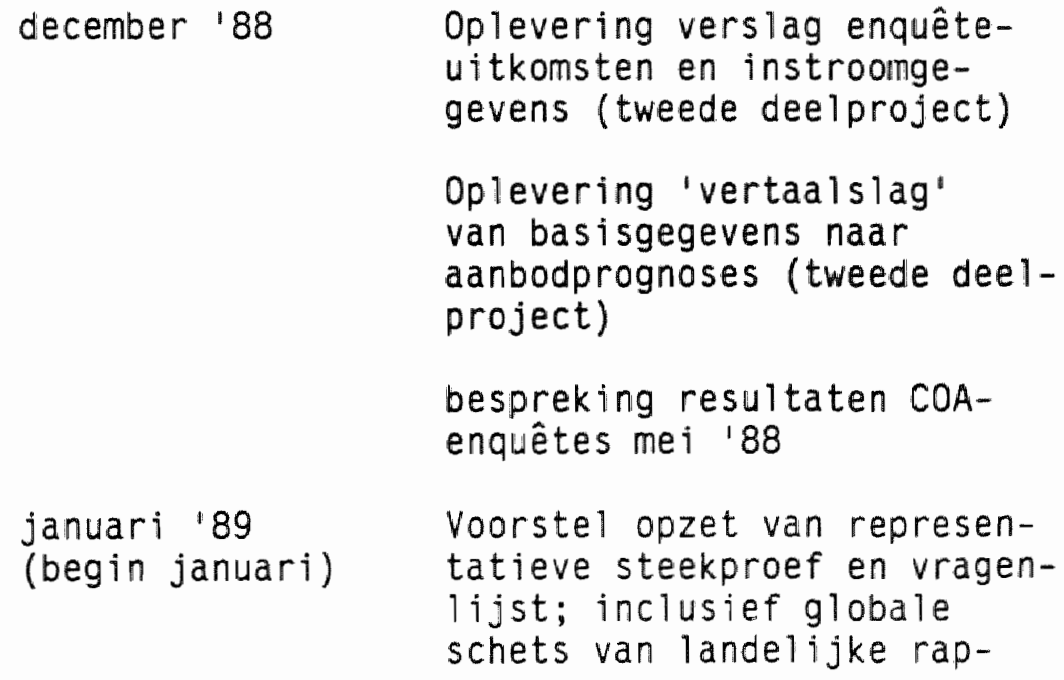

Voorstel opzet van represen-

tatieve steekproef en vragen-

lijst; inclusief globale

schets van landelijke rap-

ROA

Uit te voeren door:

CORO

ROA

CORO

COA'S, CORO, LCAS, RION, ROA

ROA

RION, LCAS/CORO

COA's, ROA

Ministerie van Sociale Zaken en Werkgelegenheid

CORO

LCAS

projectteam 
portage die op basis hiervan mogelifk is (eerste deelproject)

RION

Eventuele bijstelling regionale onderzoekspopulaties in verband met wenselijkheid ten behoeve van landelijk onderzoek. Benadering scholen hiervoor; voorlichting aan scholen (eerste deelproject)

COA's

Vaststelling vragenlijst en steekproefopzet (eerste deelproject)

COA's, RION, ROA

Oplevering onderzoeksrapport

(tweede deelproject); bespreking hiervan in projectteam

CORO/LCAS

januari/

februari 189

maart ' 89

april ' 89

(begin april)

mei ' 89

(begin mei)
Opzetten administratiebestand geënquêteerden en voorbereiden verzending enquêtes (eerste deelproject)

COA's

Selectie en implementatie softwarepakket ten behoeve van data-invoer en bijbehorende handleidingen (eerste deelproject)

RION

Gebruikersonderzoek (tweede deelproject)

LCAS

Voorstel voor standaardrapportage per school en op regionaal niveau (eerst deelproject)

RION

Vragenlijsten naar scholen; administratie voorlichten met betrekking tot verzending e.d. (eerste deelproject)

COA's

Evaluatie tweede deelproject

projectteam

Vaststellen definitieve standaardrapportage per school en op regionaal niveau (eerste deelproject)

projectteam

Verzenden vragenlijsten

(eerste deelproject)

COA's/scholen

Verzenden rappel (eerste deelproject) 
Oplevering handleiding ten behoeve van de COA's voor de standaardrapportages per regio en per school (eerste deelproject)

RION

juli /

Verwerking enquêteresul -

augustus ' 89

taten (eerste deelproject)

COA'S

Oplevering ruwe data-files

(eerste deelproject)

COA's

september '89 Oplevering standaardrapportage

per regio en per school

Oplevering landelijke

standaardrapportage

COA's

RION

oktober ' 89

Eventue le verdiepende analyses

ten behoeve van landelijke

rapportage (eerst deelproject) RION

november ' 89

Oplevering onderzoeksdesign voor meting in 1990 en daarna

RION

Oplevering inventarisatie ervaringen scholen met betrekking tot uitvoering enquête-onderzoek en oordeel schoolleiding/ schooldecaan over bruikbaarheid standaardrapportages + eigen ervaringen en commentaar (eerste deelproject)

COA's

Oplevering onderzoeksrapport

RION

RION

Inventarisatie financieringsmogelijkheden vervolgproject(en) ROA

december ' 89

Evaluatie eerste deelproject

projectteam

januari ' 90

Oplevering eindverslaggeving pilotproject RUBS 
Overeenkomst m.b.t. landelijk RUBS-project 1988-1989

\section{Partijen}

Stichting Limburgs Instituut voor Bedrijfs- en Economische Research ten deze vertegenwoordigd door prof. dr. J.A.M. Heijke, hierna te noemen LIBER

en

C.0.A. Flevoland

ten deze vertegenwoordigd door

drs. R. van $0 \mathrm{~s}$

hierna te noemen COA

In aanmerking nemende dat

- bij het LIBER is ondergebracht het Researchcentrum voor Onderwijs en Arbeidsmarkt, hierna te noemen ROA, warvan prof. dr. J.A.M. Heijke als directeur fungeert;

- in deze overeenkomst ROA als feitelijke partner van COA zal optreden;

- ROA van de Staatssecretaris van Onderwijs en Wetenschappen en de minister van Sociale Zaken en Werkgelegeriheid, in reactie op ROA's projectvoorstel d.d. 8 april 1988, de opdracht heeft gekregen om het landelijke onderzoeksproject Registratieplan Uitstroom en Besteming Schoolverlaters (RUBS) uit te voeren, zoals voorgesteld in het rapport Registratie van de Uitstroom en Bestemming van Schoolverlaters d.d. januari 1988 met de aanpassingen daarin zoals vermeld in de brief van het Ministerie van Sociale Zaken en Werkgelegenheid aan ROA d.d. 19 september 1988.

- ROA aan dit verzoek gevolg heeft gegeven onder de ontbindende voorwaarde dat het LCAS, het RION en een door het ROA voldoende geacht aantal COA's tegen bepaalde condities voor 30 november 1988 hun medewerking aan de uitvoering van genoend project zullen verlenen;

- COA op zich heeft genomen te zorgen voor de uitvoering van het RUBSproject binnen zijn regio.

- ROA daarbij op zich heeft genomen te zorgen voor een rapportage warin ten minste de volgende onderwerpen zullen worden behandeld:

- het registratie-instrument: een beschrijuing en analyse;

- de gevolgde methode bij de ontwikkeling van het registratie-instrument;

- testresultaten van dit instrument;

- hanteerbaarheid van het instrument inclusief de beperkingen;

- (tentatieve) resultaten van het gebruik van het instrument, gebruikerservaringen, reacties van schoolverlaters, scholen/dekanen;

- gemeten c.q. verwachte effecten van verschil in peildata;

- follow up van het project, naar inhoud, vorm en mogelijke financiering(sbronnen).

- ROA en COA bereid zijn met elkaar samen te werken;

- partijen te kennen hebben gegeven hun rechtsverhouding op hierna om- 
schreven wijze te willen regelen;

komen overeen

Artikel 1

1.1. ROA zal zorgdragen voor de landelijke projectcoördinatie. Hieraan zal vorm worden gegeven door de samenstelling van een projectteam warin contactpersonen van COA's, CORO, LCAS, RION en ROA zitting hebben. De contactpersoon namens ROA fungeert daarbij als coördinator van het gehele project, verzorgt de verslaglegging ten behoeve van de deelnemende instellingen en is tevens voorzitter van de teamvergaderingen.

1.2. ROA zal zorgdragen voor de in de preambule genoemde rapportage.

1.3. ROA zal zorgdragen voor de bewaking van de voortgang van de in het werkplan genoemde werkzaamheden.

1.4. COA zal de, in het bij deze overeenkomst behorende werkplan genoemde onderzoekstaken respectievelijk onderzoeksgegevens ten behoeve van ROA uitvoeren respectievelijk aan ROA overdragen.

1.5. Het werkplan d.d. 11 november 1988 makt integraal onderdeel van deze overeenkomst uit.

\section{Artikel 2}

2.1. COA is gedurende en na afloop van deze overeenkomst verantwoorde$11 j k$ voor het beheer van de door COA ten behoeve van het onderzoek verzamelde gegevens.

2.2. Vertrouwelijke gegevens die herleidbaar zijn tot natuurlijke en juridische personen, mogen uitsluitend voor het onderhavige onderzoek worden gebruikt.

COA en ROA verplicht zich hierover naar buiten toe strikte geheimhouding te betrachten en de gegevens zorguldig te bewaken.

2.3. Verstrekking van de gegevens uit het landelijke onderzoek aan derden door COA is tijdens de duur van het onderzoek niet toegestaan tenzij met voorafgaande schriftelijke toesteming van ROA.

Artikel 3

3.1. COA brengt aan ROA periodiek - conform de afspraken die daarover in het werkplan zijn gemakkt - schriftelijk verslag uit over de verrichte werkzaamheden.

3.2. COA sluit zijn onderzoekstaken af met een schriftelijke eindrapportage welke uiterlijk 15 november 1989 aan ROA wordt aangeboden.

3.3. De eindrapportage als genoemd in artikel 3.2. is in principe openbaar vanaf het moment van aanbieding, met uitzondering van de 
gevallen omschreven in artikel 4 van de wet op de Openbaarheid van Bestuur.

3.4. De auteursrechten op de resultaten van het onderzoek in welke vorm en op welke wijze dan ook weergegeven berusten bij die partij die deze resultaten genereerde.

De partij aan wie de auteursrechten in het desbetreffende geval toekomen verleent nu voor als dan aan de wederpartij het niet-exclusieve recht om bovengenoemde resultaten conform het gestelde in de hierna volgende volzin te gebruiken.

De wederpartij verplicht zich de resultaten slechts te gebruiken voor wetenschappelijk of toegepast wetenschappelijke doeleinden en bij publicatie van deze resultaten ervan melding maken bij welke partij het auteursrecht op die resultaten berust en tevens te vermelden dat de resultaten voortkomen ujt het door ROA gecoördineerde RUBS-project waaraan werd deelgenomen door LCAS, COA's en RION.

3.5. ROA verleent COA eveneens het niet-exclusieve recht om het door RION ten behoeve van het onderzoek ontwikkelde meetinstrument te gebruiken conform het gestelde in de laatste volzin van artikel 3.4 .

Artikel 4

4.1. COA en ROA zullen elkaar geen kosten in rekening brengen voor het uitvoeren van de onderzoeksopdrachten en het leveren van de onderzoeksgegevens zoals in artikel 1 genoemd.

Artikel 5

5.1. Er is sprake van een geschil als een van beide partijen schriftelijk aan de andere partij heeft laten weten dat er een geschil is.

5.2. Alle geschillen die tijdens de uitvoering van de opdracht ontstaan en die niet in gezamenlijk overleg kunnen worden opgelost zullen worden beslecht door een uitspraak van een College van Arbitrage.

Beide partijen wijzen één lid van het College van Arbitrage aan. De beide aldus aangewezen leden kiezen in overleg een derde lid tevens voorzitter van het arbitrage-college.

De voorzitter van het College mag niet in dienstverband staan tot bij het RUBS-project betrokken partijen.

Bij zijn uitspraak beslist het arbitrage-college tevens wie de kosten van de arbitrage zal dragen.

Artikel 6

Deze overeenkomst wordt aangegaan voor de duur van het landelijke RUBS-project 1988-1989 aflopend op 1 februari 1990, onder de ontbindende voorwaarde dat ROA uiterlijk op 30 november 1988 met het LCAS, het RION en een voor ROA voldoende aantal COA's contractuele overeen- 
steming heeft bereikt over de uitvoering van de aan genoemde organisaties op te dragen onderzoekstaken in het kader van het RUBS-project.

\section{Aldus overeengekomen}

op 24 noterbed 1988

op 24 novembed 1988

te Mastricht,

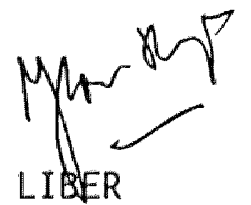

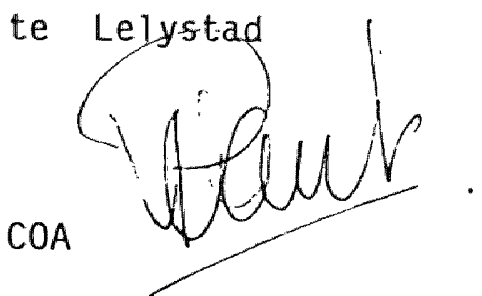


RUBS

Verwerkingsformulier

voor het onderzoek onder non-respondenten

(schoolverlaters 1987/88)
A. Gegevens uit de schooladministratie (in te vullen door de school)

1 Geboren:

maand:

jaar

19.

2. Geslacht

$\begin{array}{ll}\operatorname{man} & 1 \\ \text { vrouw } & \end{array}$

3. Culturele minderheldsgroep/allochtone learling

nee

ja

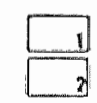

4. Vorig Jaar dlploma behaald?

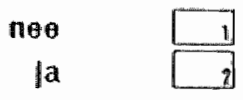

5. Zo nee, ult welke klas de school verialen?

klas:

B. Verloop van de telefonische benadering (In te vullan door de school)

6. Wat is het elndresultaatvan uw pogingen de ex leerling telefonlsch to benaderen?
a Gehoor gekregen medewerking
welgerlng herhaaldellik nlet thuts (blok C beantwoord door hulsgenool)

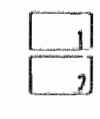
geon telefoon
b. Geen gehoor gekregen
teleloonnummer klopt nlel of nlat maer (bilv door varhulzing) herhaaldalljk nlat opgenomen

hler alknippen

\section{Hulpgegevens}

Naam:

telefoonnummer:

\section{benadering opmerkingen}

eerste kear

- weede kear

derde keer 
C. Voornaamste huidige bezigheid

(loleronisch to vragen aan die ox loeriling)

7 VMAAG

Vorig jaar ben je bij ons van school gegaan. We zijn benieurwd naar wat je nu doet.

Wat was op 1 mei van dit jaar (....maanden geleden dus)

je voornaamste bezigheid?

(Hot antwoord loekennen aan 66 n van de volgende categorieen :)

a. Full time dagopleiding (meer dan drle dagen per week)

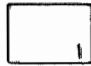

Wal voor oplelding?

(bljv. MEAO bestuuri|jke richting)

b. Opleiding in het Leerlingwezen (Streekschool e.d.) of in-service opleiding in de verpleging/verzorging

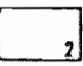

Wal voor oplelding?

(bljv. automonteur by hel Leerlingstalsel VAM)

c. Betaalde baan

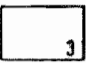

BeroepNunctle:

Ardellng:

Uron por wook:

d. Werkloos

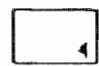

Wel gewerkt? nee

- Militaire dienst

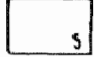

1 Huishouden

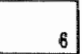

g. Anders, namelljk

Hulpgegevens

Naam:

telefoonnummer: 